\title{
Production of Butyric Acid and Butanol from Biomass
}

Final Report

Work Performed Under:

Contract No.: DE-F-G02-00ER86106

For:

U.S. Department of Energy

Morgantown, WV

By

David Ramey

Environmental Energy Inc.

1253 N. Waggoner Road

P.O. Box 15

Blacklick, Ohio 43004

And

Shang-Tian Yang

Department of Chemical and Biomolecular Engineering

The Ohio State University

140 West $19^{\text {th }}$ Avenue

Columbus, Ohio 43210 


\section{Table of Contents}

Page

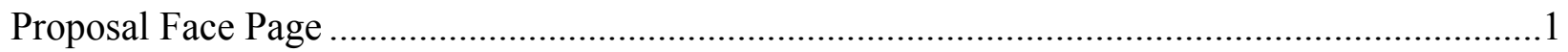

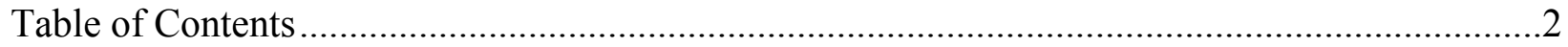

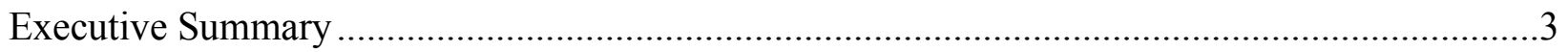



Phase II Technical Objectives and Tasks.......................................................................

A. Enhanced butanol production from glucose and butyrate ...............................................

B. Development of butyric acid over-producing strains .................................................23

C. Optimization and Scale-Up of Fibrous Bed Bioreactor ..................................................47

D. Develop Separation Techniques for Butanol Recovery from Fermentation..........................52

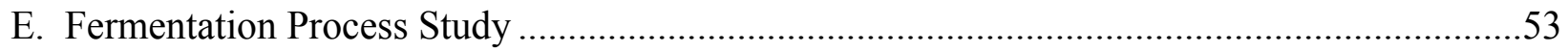

F. Scale Up to a Prototype Demonstration Plant …........................................................5

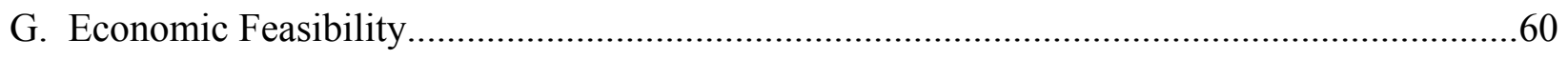

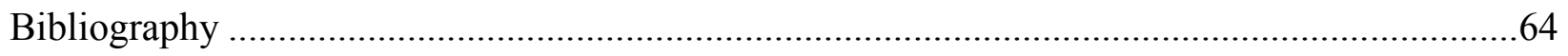

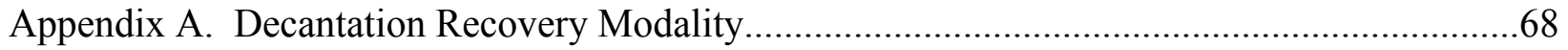

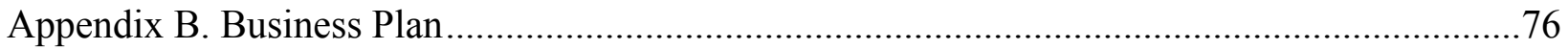

Appendix C. Final Demonstration of the Efficacy of BUTANOL To Replace Gasoline Gallon for Gallon 


\section{Executive Summary}

Butanol replaced gasoline gallon for gallon in a 10,000 miles trip across the United States without the need to highly modify a ' 92 Buick (your existing car today). Butanol can now be made for less than ethanol and yields more Btu's from the same corn, making the plow to tire equation positive - more energy out than it takes to make it and Butanol is much safer. Butanol when substituted for gasoline gives better gas mileage and does not pollute as tested in 10 states. Butanol should now receive the same recognition as ethanol in U.S. legislation "ethanol/butanol". There is abundant plant biomass present as low-value agricultural commodities or processing wastes requiring proper disposal to avoid pollution problems. One example is in the corn refinery industry, which processes more than $13 \%$ of the $\sim 9.5$ billion bushels ( $\sim 240$ million metric tons) of corn annually produced in the U.S. to produce highfructose-corn-syrup, dextrose, starch, and fuel alcohol, and generates more than 10 million metric tons of corn byproducts that are currently of limited use and pose significant environmental problems. The abundant inexpensive renewable resources as feedstock for fermentation, and recent advances in the fields of biotechnology and bioprocessing have resulted in a renewed interest in the fermentation production of chemicals and fuels, including n-butanol.

The historic acetone-butanol-ethanol (ABE) fermentation by Clostridium acetobutylicum is one of the oldest known industrial fermentations. It was ranked second only to ethanol fermentation by yeast in its scale of production, and is one of the largest biotechnological processes ever known. However, since the 1950's industrial ABE fermentation has declined continuously, and almost all butanol is now produced via petrochemical routes (Chemical Marketing Reporter, 1993). Butanol is an important industrial solvent and is a better fuel for replacing gasoline gallon for gallon than ethanol. Current butanol prices as a chemical are at $\$ 3.00$ per gallon wholesaling in 55 gallon drums for $\$ 6.80$, with a worldwide market of 1.4 billion gallon per year. The market demand is expected to increase dramatically since butanol can now be produced economically from low-cost biomass. Butanol's application as a replacement for gasoline will outpace ethanol, biodiesel and hydrogen when its safety and simplicity of use are seen. Butanol's application for the Department of Defense as a clean-safe replacement for batteries when used in conjunction with fuel cell technology is seen as an application for the future. Disposable canisters made of PLA that carry butanol to be reformed and used to generate electricity for computers, night vision and stealth equipment can be easily disposed of.

In a typical $\mathrm{ABE}$ fermentation, butyric, propionic and acetic acids are produced first by $C$. acetobutylicum; the culture then undergoes a metabolic shift and solvents (butanol, acetone, and ethanol) are formed (Fond et al., 1985). In conventional ABE fermentations, the butanol yield from glucose is low, typically at $\sim 15 \%(\mathrm{w} / \mathrm{w})$ and rarely exceeds $25 \%(0.77-1.3$ gallons per bushel corn respectfully). The production of butanol is also limited by severe product inhibition. Butanol at a concentration of $10 \mathrm{~g} / \mathrm{L}$ can significantly inhibit cell growth and the fermentation. Consequently, butanol titers in conventional ABE fermentations are usually lower than $13 \mathrm{~g} / \mathrm{L}$. The low butanol yield and butanol concentration made butanol production from glucose by ABE fermentation uneconomical.

In the past $20+$ years, there have been numerous engineering attempts to improve butanol production in $\mathrm{ABE}$ fermentation, including using cell recycle and cell immobilization to increase 
cell density and reactor productivity and using extractive fermentation to minimize product inhibition. Cell immobilization benefits ABE fermentation by increasing cell density and producing cell-free product streams that are easier for product recovery. Also, extractive fermentation with in-situ butanol removal from the fermentation broth has been shown to improve the fermentation productivity by twofold as well as butanol yield. Despite all these efforts, the best results ever obtained for ABE fermentations to date are still less than $20 \mathrm{~g} / \mathrm{L}$ in butanol concentration from fermentation, $4.5 \mathrm{~g} / \mathrm{L} / \mathrm{h}$ in butanol productivity, and a butanol yield of less than $25 \%(\mathrm{w} / \mathrm{w})$ from glucose (1.29 gallons per bushel).

As a direct result of this contract the ancillary products of fermentation are eliminated and therefore more sugars go towards the end product - Butanol. The high yielding butanol process (US Patent. No. 5,753,474 "Continuous Two Stage, Dual Path Anaerobic Fermentation of Butanol and Other Organic solvents Using Two Different Strains of Bacteria") eliminates production of all the ancillary byproducts; the process uses carbohydrates to manufacture only butyric acid, which is converted to butanol in the second stage. The improvement in butanol yield, along with increasing the fermentation rate, volumetric productivity, stability and butanol tolerance by the bacteria is attributed to the fibrous-bed bioreactor-FBB (US Patent No. 5,563,069 "Extractive Fermentation Using Convoluted Fibrous Bed Bio-reactor") and has surpassed all expectations. The efficacy of the FBB reactor and the dual path fermentation gave a maximum yield of $49 \%$ (2.5 gallons per bushel), Volumetric Productivity of $30 \mathrm{~g} / \mathrm{l} / \mathrm{h}$, at a Dilution Rate of 3.5/h. Estimated cost of production is $\$ 0.15$ per pound ( $\$ 1.07 /$ gallon) butanol. This approaches a theoretical maximum yield of 2.8 gallons butanol per bushel corn possible. This increases the Btu's derived from a bushel of corn by $25 \%$ when compared to ethanol. More energy out for less costs.

In an effort to solve another environmental problem EEI is approaching the cheese industry to deal with the whey lactose disposal. Lactose is an ideal source of sugar for the first microbe used to convert sugar to butyric acid and is the bane of the industry. Clostridium tyrobutyricum loves lactose and causes cheese wheels to "blow out". By using this source of sugar, that has been Ultra High Filtered to remover butter fat and proteins, we eliminate the cost of corn overhead (40\% typical in ethanol processes) each year, eliminate $23 \%$ the cost of material handling equipment to process corn and the costs of operations of the material handling system, all of which leads to butanol being produced for $\$ 0.08$ per pound on Whey Permeate ( $\$ 0.54$ per gallon butanol).

To demonstrate the gallon for gallon replacement of gasoline with butanol an unmodified '92 Buick has been driven 10,000 miles across the United States from Columbus, Ohio to California via Phoenix and back via Denver Colorado to Washington DC (July-August 2005). The butanol powered Buick gets 20-26 miles per gallon. And in 10 states E-Test facility - Butanol's average reduction of Hydrocarbons was 95\%, Carbon monoxide to $97 \%$, Oxides of Nitrogen by $27 \%$ and had a background of only $14.7 \%$ Carbon Dioxide.

Commercialization of this new technology will have a profound impact on this Nations energy policy, has the propensity to reduce our Nation's dependence on foreign oil and protect the fuel generation from sudden disruption by disseminating production of fuel throughout the country's bio-belt instead of being centralized along coastal regions of the United States. It will take years 
before butanol is seen in gasoline as ethanol is today because of the endless testing that has to be done. Many jobs will be created from this action. However Butanol's first market is not as fuel but as an industrial solvent where it sells for 2.5 to 3 times the price of gasoline and is the entry point for Environmental Energy Inc. However Butanol's local distribution to the fuels market may prove to be more efficacious and cost effective when considering the ease of distribution to existing vehicles of environmentally conscious consumers who also want a solution to the ever rising prices at the pump. This will eliminate the costs of distribution and material handling which is required by the Industrial Commodity Market - rail cars, barges, logistics etc.. Local farmers will supply fuel to local customers - a Value Added product circulating local money several times within the community.

The summary business plan for Phase III is contained in Appendix 1. As we approached commercialization many sources of advice were taken and it was pointed out that Environmental Energy is a great "Home Run" but has no exit strategy - how do you get to first base. First base is the ability for investors to invest and have a 5-6 year exit strategy with a profit. To this end Environmental Energy developed a sister company (ChemLac) which deals with the cheese industry and uses lactose as a feedstock along with various EEI's technology and Know-How to produce various acids, solvents, esters and of course butanol from the research carried out by this DOE/STTR grant.

ChemLac Inc was formed in 2004 and is the vehicle to show a healthy profit and exit point. We found that our primary Agribusiness contacts wanted our technology and Know-How to make propionic acid and ammonium propionate. This association with Agribusiness \#1 will allow us to stage our pre-commercial scale-up of the work by using a single reactor with a different microbe to produce the propionic acid and ammonium propionate. Agribusiness $\# 2$ is in negotiations and desires our fumaric acid work and that again uses a single FBB reactor. Both these opportunities allow EEI to enter commercialization of the butanol steam in an orderly manner and allow us to sell our pre-commercial scale units 2-5 million gallons of butanol per year to the cheese industry. Since most cheese manufactures produce 2-5 million pounds of whey per day it is an ideal size which can be scaled to their purposes. 30-50 million gallons per year biorefineries to produce butanol have the advantage of several small facilities to make any major changes in before investing in larger plants as is seen in the refining industry.

Environmental Energy has established a web site which has helped find and qualify interested parties and began the long educational effort to raise public awareness that butanol replaces gasoline.

Visit: www.butanol.com and the Cross-Country Trip Diary http://360.yahoo.com/dramey756 


\section{Introduction}

Butanol replaced gasoline gallon for gallon in a 10,000 miles trip across the United States without the need to highly modify a '92 Buick (your existing car today). Butanol can now be made for less than ethanol and yields more Btu's from the same corn, making the plow to tire equation positive - more energy out than it takes to make it and Butanol is much safer. Butanol when substituted for gasoline gives better gas mileage and does not pollute as tested in 10 states. Butanol should now receive the same recognition as ethanol in U.S. legislation "ethanol/butanol". There is abundant plant biomass present as low-value agricultural commodities or processing wastes requiring proper disposal to avoid pollution problems. One example is in the corn refinery industry, which processes more than $13 \%$ of the $\sim 9.5$ billion bushels ( $\sim 240$ million metric tons) of corn annually produced in the U.S. to produce highfructose-corn-syrup, dextrose, starch, and fuel alcohol, and generates more than 10 million metric tons of corn byproducts that are currently of limited use and pose significant environmental problems. The abundant inexpensive renewable resources as feedstock for fermentation, and recent advances in the fields of biotechnology and bioprocessing have resulted in a renewed interest in the fermentation production of chemicals and fuels, including n-butanol (Durre, 1998; Somrutai et al, 1996; Claassen et al, 1999).

The acetone-butanol-ethanol (ABE) fermentation by Clostridium acetobutylicum is one of the oldest known industrial fermentations. It was ranked second only to ethanol fermentation by yeast in its scale of production, and is one of the largest biotechnological processes ever known. However, since the 1950's industrial ABE fermentation has declined continuously, and almost all butanol is now produced via petrochemical routes (Chemical Marketing Reporter, 1993). Butanol is an important industrial solvent and potentially a better fuel extender than ethanol. Current butanol prices as a chemical are at $\$ 3.50$ per gallon with a worldwide market of 1.4 billion gallon per year. The market demand is expected to increase dramatically if butanol can be produced economically from low-cost biomass (Durre, 1998).

In a typical $\mathrm{ABE}$ fermentation, butyric and acetic acids are produced first by $C$. acetobutylicum; the culture then undergoes a metabolic shift and solvents (butanol, acetone, and ethanol) are formed (Fond et al., 1985). Figure 1 shows the metabolic pathways in ABE fermentation. Increasing butyric acid concentration to $>2 \mathrm{~g} / \mathrm{L}$ and decreasing the $\mathrm{pH}$ to $<5$ usually are required for the induction of a metabolic shift from acidogenesis to solventogenesis (Gottschalk and Morris, 1981; Gottwald and Gottschalk, 1985; Monot et al., 1984). However, the actual fermentation is quite complicated and difficult to control (Chauvatcharin et al., 1998). In conventional ABE fermentations, the butanol yield from glucose is low, typically at $\sim 15 \%(\mathrm{w} / \mathrm{w})$ and rarely exceeds $25 \%$ (0.77-1.3 gallons per bushel corn respectfully). The production of butanol is also limited by severe product inhibition. Butanol at a concentration of $10 \mathrm{~g} / \mathrm{L}$ can significantly inhibit cell growth and the fermentation. Consequently, butanol titers in conventional ABE fermentations are usually lower than $13 \mathrm{~g} / \mathrm{L}(1.3 \%)$. The low butanol yield and butanol concentration make butanol production from glucose by ABE fermentation uneconomical (Maddox, 1989).

In the past $20+$ years, there have been numerous engineering attempts to improve butanol production in $\mathrm{ABE}$ fermentation, including using cell recycle and cell immobilization to increase 
cell density and reactor productivity and using extractive fermentation to minimize product inhibition (Geng and Park, 1994; Groot et al., 1991; Maddox et al, 1995; Mollah and Stuckey, 1993; Mulchandani and Volesky, 1994; Park et al., 1990; Qureshi and Blaschek, 1999; Qureshi and Maddox, 1995; Yang and Tsao, 1995). For example, ABE fermentation with cell recycle using a spin filter perfusion bioreactor, $49 \mathrm{~g} / \mathrm{L}$ of cell mass was achieved and the process gave a butanol productivity of $1.14 \mathrm{~g} / \mathrm{L} / \mathrm{h}$. Cell immobilization benefits ABE fermentation by increasing cell density and producing cell-free product streams that are easier for product recovery (Mulchandani and Volesky, 1994). Also, extractive fermentation with in-situ butanol removal from the fermentation broth has been shown to improve the fermentation productivity by twofold as well as butanol yield (Qureshi and Blaschek, 1999). Despite all these efforts, the best results ever obtained for ABE fermentations to date are still less than $20 \mathrm{~g} / \mathrm{L}$ in butanol concentration from fermentation, $4.5 \mathrm{~g} / \mathrm{L} / \mathrm{h}$ in butanol productivity, and a butanol yield of less than $25 \%(\mathrm{w} / \mathrm{w}$ ) from glucose.

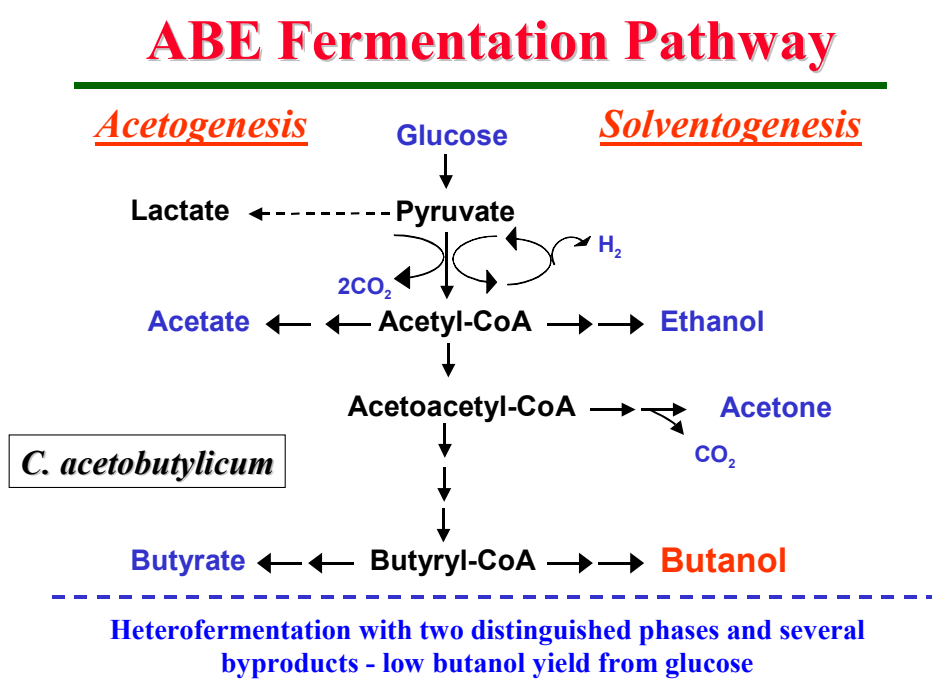

Figure 1. ABE fermentation pathways of C. acetobutylicum.

More recently, genetic engineering and metabolic engineering of $C$. acetobutylicum have been studied as promising methods to overcome the aforementioned problems in ABE fermentations (Young et al., 1989). Inactivation of solR gene (coded for a putative repressor for butanol and acetone formation) via homologous recombination yielded a mutant with 3.2-fold increase in the final butanol concentration; and mutant strain with overexpression of plasmid encoded aad gene increased butanol concentration to $16.4 \mathrm{~g} / \mathrm{L}$ from $13.1 \mathrm{~g} / \mathrm{L}$ as the upper limit for wild types (Nair, et al., 1999). Inactivation of pta gene reduced phosphotransacetylase (PTA) and acetate kinase (AK) activities and significantly reduced acetate production; while inactivation of buk gene reduced butyrate kinase (BK) activity and significantly reduced butyrate production and increased butanol production (Green and Bennett, 1998). The final butyrate levels were 52-77\% lower, butanol levels up to $50 \%$ higher, and acetone levels $20-50 \%$ lower than wild type. However, butyrate was not completely abolished and butanol yield from glucose was only marginally improved, possibly due to the existence of other isozymes which catalyze butyrate production. New approach using antisense RNA (as RNA) as a metabolic engineering tool to down-regulate genes involved in butyrate formation has also been studied and shown to result in 
$50 \%$ and 35\% higher final titers of acetone and butanol, respectively (Desai and Papoutsakis, 1999). Although these genetic engineering approaches are promising and the complete genome sequence of the type strain (C. acetobutylicum ATCC 824) is available (www.ncbi.nih.gov), progress in this area has been slow because the complexity in ABE fermentation pathways and genetic controls involved in the metabolism are difficult to manipulate. To date, no genetically engineered Clostridia can meet the requirements for industrial butanol production use.

In this project, we proposed a novel approach using two sequential fermentation steps to shortcut the complex ABE fermentation pathway by directing glucose fermentation to butyric acid and then to butanol. By separating the acid (butyric acid) production (using C. tyrobutyricum) from solvent (butanol) formation (using C. acetobutylicum), more glucose carbon can be used for butanol production, and a higher butanol yield of $>40 \%(\mathrm{w} / \mathrm{w})$ can be expected, which is almost $100 \%$ higher than that from conventional ABE fermentations. The new process also allows both bacteria to work under their respective optimal $\mathrm{pH}$ and temperature conditions, and thus increased reactor productivity to $8-15 \mathrm{~g} / \mathrm{L} / \mathrm{h}$, especially when extractive fermentation was used to remove butanol from the bioreactor. Figure 2 illustrates such a two-step fermentation process for butanol production from glucose. A small amount of glucose is also provided along with butyrate to the second fermentation to provide the needed energy source for the bacteria; butyrate does not serve as a good energy source for the bacteria. Using immobilized cells and maintaining the cells in the stationary (solventogenesis) phase minimized the energy consumption by the cells. The concept feasibility of this two-step fermentation was evaluated in Phase I, and the process was further studied and optimized in Phase II. The extraction methods for butanol separation and extractive fermentation were investigated in Phase II.



Figure 2. A two-step fermentation process to convert glucose to butyrate and then to butanol.

This project is a joint effort between Environmental Energy Inc. (EEI) and The Ohio State University (OSU). We are applying OSU's U.S. Patent 5,563,069 "Extractive Fermentation Using Convoluted Fibrous Bed Bio-reactor" and EEI's U.S. Patent 5,753,474 "Continuous Two Stage, Dual Path Anaerobic Fermentation of Butanol and Other Organic Solvents Using Two Different Strains of Bacteria" for economical production of butanol from biomass. Bacteria that express a solventogenesis phase physiology, such as C. acetobutylicum, waste a tremendous 
amount of available carbon (e.g., glucose) on multiple byproducts. By first going through acidogenesis (first stage) where feedstock carbohydrates are converted into multiple acids and then as the acids build up the microbe changes to solventogenesis (second stage) and begins consuming the acids to produce the correlated solvents/alcohols. The advantage of this class of microbes is that they do consume acids and produce associated solvents. EEI's patent is based on this fermentation nature and separates the fermentation into two steps: step one converts incoming carbohydrates to one specific acid and step two converts that acid into its associated solvent/alcohol. Preliminary laboratory studies and theoretical analysis based on metabolic pathway indicated that the new process could increase butanol yield from a bushel of corn by almost $100 \%$ compared to conventional batch processes (1.3 gallons per bushel to our 2.5 gallons per bushel). The results of this Phase II contract has seen these numbers proven.

One key step in the new process is the butyric acid fermentation since the major carbon loss occurs during butyric acid production. In general, the selectivity for butyrate (ratio of butyrate to total acids produced) is strongly favored at a low cell growth rate. In the Phase I study, we used OSU's proprietary fibrous-bed bioreactor (FBB) for butyric acid production to obtain the highest possible butyrate concentration and yield from glucose. The FBB has a simple, scaleable packing design for cell immobilization, and has been demonstrated for continuous long-term production of propionic acid with $100 \%$ improvements in product yield, productivity, and final product concentration over the conventional fermentation process (Yang et al., 1994; 1995). Butyric acid production from glucose by $C$. tyrobutyricum in an FBB gave a high yield of $\sim 50 \%(\mathrm{w} / \mathrm{w})$ and a high butyrate concentration of $>43 \mathrm{~g} / \mathrm{L}$. It has been demonstrated that the butanol yield from butyric acid in the second step fermentation using C. acetobutylicum was close to the theoretical yield of $84 \%(\mathrm{w} / \mathrm{w})$. Thus, the overall butanol yield from glucose in the two-step fermentation process was increased to $>40 \%(\mathrm{w} / \mathrm{w})$.

\section{Phase II Technical Objectives and Tasks}

A. Develop mutant strains for enhanced butanol production

B. Develop metabolically engineered strains for enhanced butyric acid production from glucose and xylose

C. Optimize and scale up the fibrous bed bioreactor for fermentation

D. Develop separation techniques for butanol recovery from fermentation

E. Demonstrate the feasibility of producing butanol from glucose using the proposed two-step continuous fermentation process

F. Optimize and scale up the process to a prototype demonstration plant

G. Evaluate economic feasibility

\section{A. Enhanced butanol production from glucose and butyrate}

\section{Background}

Since the turn of the last century Clostridium acetobutylicum has been bred, mutated and investigated. Historically, ABE fermentation produces acetone, butanol and ethanol in a 3:6:1 ratio respectively ( $\sim 1.3$ gallons butanol, 0.65 gallon acetone and 0.22 gallons ethanol per bushel 
corn) with a total solvent concentration of only $\sim 1.5 \%$. The advancements in science have spawned a multitude of new research, since today the microbiologist can cause specific mutations to occur with genetic engineering, whereas in the past microbiologist had to strain to find the mutations and then map their advantages. As a result many mutants show an increase in butanol generation while reducing acetone and ethanol. Several strains are being studied for their application in continuous fermentation processes.

More recently, Genge and Park $(1993,1994)$ have investigated a low acid producing Clostridium acetobutylicum B-18, and pervaporation recovery techniques, but still they produce ancillary acids and solvents. Blaschek at Champaign, Ill has raised the final concentration of butanol in corn-steep liquor -- a low-value byproduct of corn wet-milling -- from 1 percent to 2 percent, "a small change that brings a huge reduction in energy costs required to recover the butanol,". Claiming that butanol producers may return to the corn fields following this dramatic improvement in the fermentation process. Scale-up of an integrated fermentation and recovery process for commercialization of butanol is taking place at MBI, Lansing, Michigan under the direction of Ponnam Elankovan. The research centers around ATCC 55025 which falls under US Patent 5,192,673 "Mutant stain of C. acetobutylicum and process for making butanol" held by Mahendra and Jain of MBI and the recovery modality of pervaporation. Their research increases the butanol boundary values but still produces other solvents, acids and alcohols. B.K. Soni also works closely with the team and has published many important articles on butyrate uptake that are useful to our research. Meyer and Papoutsakis identified patterns of energetics and product formation kinetics back in 1989, and still much research has been done to define the switch from acidogenesis to solventogenesis and the aid nutrition plays, the importance of cell physiology. Papoutsakis and his collaborators at Northwestern and Rice University are taking genetic and metabolic engineering approaches to create new mutants with improved characteristics for butanol production. Many countries such as France, Italy, England, Japan and other nations are doing landmark research and contributing to all our goals - a Butanol economy.

Still in most articles it is referred to as the acetone, butanol, and ethanol (ABE) fermentation. EEI's process refers only to butanol for that is the product of choice and by letting the microbes create mainly butanol the process becomes attractive economically. Butanol sells for about twice as much as acetone and three times as much as ethanol, plus unlike ethanol's early years there is a well established industrial solvent market for butanol as paint thinner. The technical feasibility of this concept has been proven in Phase I. Phase II focused on the development of butanol tolerance, characterization of an asporogenic strain, and optimization of fermentation conditions for enhanced butanol production from glucose and butyrate.

\section{Microorganism and Media}

C. acetobutylicum was used for the study of butanol production from glucose and butyric acid. The most commonly used strains (ATCC 4259 and 824) and one asporogenic strain (ATCC 55025) were studied. They were cultured in laboratory FBB and adapted to tolerate higher butanol and butyrate concentrations. The same basic medium was used for all strains studied, with the following composition (per liter of distilled water): $\mathrm{MgCl}_{2} \cdot 6 \mathrm{H}_{2} \mathrm{O}, 1 \mathrm{~g}$; $\mathrm{SO}_{4}\left(\mathrm{NH}_{4}\right)_{2}, 1.5 \mathrm{~g}$; $\mathrm{KH}_{2} \mathrm{PO}_{4}, 0.5 \mathrm{~g} ; \mathrm{FeSO}_{4} \cdot 7 \mathrm{H}_{2} \mathrm{O}, 10 \mathrm{mg} ; \mathrm{MnSO}_{4} \cdot \mathrm{H}_{2} \mathrm{O}, 10 \mathrm{mg} ; \mathrm{CaCl}_{2} \cdot 2 \mathrm{H}_{2} \mathrm{O}, 0.15 \mathrm{~g}$; yeast extract, 5 $\mathrm{g}$; glucose $30 \mathrm{~g}$; and vitamin solution, $10 \mathrm{~mL}$. Depending on the studies, glucose may be replaced 
with other carbon source and at different concentrations. The vitamin solution per liter contains 5 $\mathrm{mg}$ of thiamine-HCl; $5 \mathrm{mg}$ of riboflavin; $5 \mathrm{mg}$ of nicotinic acid; $5 \mathrm{mg}$ of Capantothenate; $0.1 \mathrm{mg}$ of vitamin $\mathrm{B}_{12} ; 5 \mathrm{mg}$ of $p$-aminobenzoic acid; $5 \mathrm{mg}$ of lipoic acid. In continuous fermentation, a modified medium with corn steep liquor as the nitrogen source was used. The growth temperature of the culture was maintained at a constant temperature (between 30 and $37^{\circ} \mathrm{C}$ ). The fermentation was maintained at a controlled $\mathrm{pH}$ level by adding $\mathrm{NaOH}$ or ammonia.

\section{Factors affecting ABE fermentation}

Two most important parameters that affect the formation of butanol are the $\mathrm{pH}$ condition, including both external $\mathrm{pH}$ and internal $\mathrm{pH}$, and the concentrations of the acids (butyric and acetic) produced. During the acidogenic phase of growth, the internal $\mathrm{pH}$ decreases in parallel with the decrease in the external $\mathrm{pH}$ due to the formation of acids, but the internal $\mathrm{pH}$ did not go below 5.5 throughout the batch growth (Terracciano and Kashket, 1986). As the external $\mathrm{pH}$ varied between 5.9 and 4.3, the cells kept a constant $\Delta \mathrm{pH}$ of 0.9 to 1.3 (Gottwald and Gottschalk, 1985). Certain levels of butyric and acetic acid concentration are essential for the induction of butanol formation (Bahl, et al., 1982; Fond, et al., 1985; Gottschalk and Morris, 1981; Holt, et al., 1984; Martin, et al., 1983; Monot, et al., 1984; Terracciano and Kashket, 1986). But due to the complicated metabolic mechanisms involved during the induction of solvent formation, the exact concentration levels required still remains controversial. It is commonly believed that a minimum of $10 \mathrm{mM}$ (i.e. $0.88 \mathrm{~g} / \mathrm{L}$ butyric or $0.6 \mathrm{~g} / \mathrm{L}$ acetic acid) acids were necessary to induce the solventogenesis (Gottschalk and Morris, 1981; Terracciano and Kashket, 1986). With an elevated concentration of acids initially added to the medium, the induction of solvent production was initiated at an earlier stage, but it does not necessarily improve the final production of butanol (Gottschalk and Morris, 1981). It has been reported that at different initial acetic and butyric concentrations, the total solvent and the ratio of solvents (acetone/butanol/ethanol) to be produced was changed (Martin, et al., 1983). Several other parameters were also found to affect the butanol production, including temperature, vitamin concentrations and other medium compositions. $37^{\circ} \mathrm{C}$ is required for normal metabolic activity of C. acetobutylicum (Soni and Jain, 1997). Two basic vitamins required to maintain active growth of the culture are biotin and $p$-aminobenzoic acid (PABA), with PABA being the limiting factor. Increasing the vitamin concentrations by 8 -fold from $0.01 \mathrm{mg} / \mathrm{L}$ biotin and $1.0 \mathrm{mg} / \mathrm{L}$ PABA was found to have increased both biomass growth rate and solvent formation rate (Soni, et al., 1987). Other medium compositions have also been reported to affect the solvent production (Soni, et al., 1987).

The effect of $\mathrm{pH}$ in the range of 4 to 5.5 was evaluated to determine the optimal $\mathrm{pH}$ for butanol production. The effects of externally added butyrate on butanol production were also studied to establish the optimal butyrate/glucose ratio for butanol production. The detail of this study has been published (Appl. Biochem. Biotechnol., 113-116:887-898, 2004) and is described in the following section. 


\title{
A.1 Continuous Production of Butanol by Clostridium acetobutylicum Immobilized in a Fibrous Bed Bioreactor
}

\begin{abstract}
An investigation was undertaken to explore the influence of dilution rate and $\mathrm{pH}$ in continuous cultures of Clostridium acetobutylicum. A 200-ml fibrous bed bioreactor was used to produce high cell density and butyrate concentrations at $\mathrm{pH} 5.4$ and $35{ }^{\circ} \mathrm{C}$. By feeding glucose and butyrate as a co-substrate, the fermentation was maintained in the solventogenesis phase, and the optimal butanol productivity of $4.6 \mathrm{~g} \mathrm{l}^{-1} \mathrm{~h}^{-1}$ and yield of $0.42 \mathrm{~g} \mathrm{~g}^{-1}$ (2.2 gallons per bushel corn) were obtained at the dilution rate of $0.9 \mathrm{~h}^{-1}$ and $\mathrm{pH} 4.3$. Compared to the conventional ABE fermentation, the new fermentation process greatly improved butanol yield, making butanol production from corn an attractive alternative to ethanol fermentation.
\end{abstract}

\section{Introduction}

Fermentation processes using anaerobic microorganisms provide a promising path for converting biomass and agricultural wastes into chemicals and fuels (1). Acetone-butanol-ethanol fermentation (ABE fermentation) with the strict anaerobic bacterium, Clostridium acetobutylicum, was once (1917-1955) one of the largest fermentation processes ever developed in industry. However, with a few exceptions, anaerobic fermentation processes for production of fuels and chemicals, including $\mathrm{ABE}$ fermentation, usually suffer from a number of serious limitations including low yields, low productivity, and low final product concentrations (2-3). It is likely that the fermentation route is now competitive with petroleum-based solvent synthesis because the limitations are now overcome (4). However, U.S. legislation to produce strategic chemicals, fuels, and energy from domestic renewable resources and the need to lessen the dependence on the diminishing petroleum supplies has resulted in the renaissance of the fermentation process as a possible source of solvents (5-7). U.S. Legislation needs to be changed to include Butanol i.e.: "ethanol/butanol" or "poly-carbon alcohols" (alcohols with more than one carbon atom which still eliminates methanol as originally sought by legislation when ethanol was specified) should be used so Butanol can reap the same subsidies that ethanol now entertains.

Butanol has many characteristics that make it a better fuel than ethanol, now used in the formulation of gasohol (8). Butanol can solve many problems associated with the use of ethanol. Butanol has the following advantages over ethanol: (a) butanol has 25\% more Btu per gallon; (b) butanol is less evaporative/explosive with a Reid vapor pressure (RVP) 7.5 times lower than ethanol; (c) butanol is safer than ethanol because of its higher flash point and lower vapor pressure; (d) butanol has a higher octane rating (9); (e) butanol is more miscible with gasoline and diesel fuel but less miscible with water (10). Petroleum-derived butanol is currently used in food and cosmetic industries as an extractant Bio-butanol is preferred (11), because there are concerns of its carcinogenic aspects associated with the residual petroleum components. Many new uses will occur in these fields as "green" butanol becomes available to the market. Other uses include current industrial applications in solvent (paint thinner), rubber monomers and break fluids. Butanol has the propensity to solve hydrogen infrastructure problems associated with fuel cell use of the future. Dispersed through existing pipelines and filling stations and then butanol can be reformed onboard the fuel cell vehicle, butanol offers a safer fuel with more 
hydrogen than methanol (very dangerous) or ethanol. Even though there is less hydrogen per molecular mass, what is lost is gained in safety and ease of distribution capabilities.

The present research on butanol fermentation has been focused primarily on the effects of $\mathrm{pH}$ and dilution rate (D) in continuous cultures of the mutant strain from $C$. acetobutylicum ATCC 55025. To overcome the problems of low productivity and yield of butanol, cell immobilization in a convoluted fibrous bed bioreactor (FBB) and feeding with dextrose and butyric acid as cosubstrates to produce butanol and reduce production of ancillary byproducts were used in the fermentation. By changing the dilution rate from $0.1 \mathrm{~h}^{-1}$ to $1.2 \mathrm{~h}^{-1}$ at $\mathrm{pH} 4.3$ and varying the $\mathrm{pH}$ from 3.5 to 5.5 at the dilution rate of $0.6 \mathrm{~h}^{-1}$, the optimal conditions for high productivity and butanol yield were investigated.

\section{Materials and Methods}

\section{Bacterial culture and Media}

Clostridium acetobutylicum ATCC 55025 was cultured in $38 \mathrm{~g} \mathrm{l}^{-1}$ Reinforced Clostridial Medium (Oxoid CM149, Hampshire, England) supplemented with $20 \mathrm{~g}^{-1}$ glucose (Sigma Chemical Co.). Oxoid Reinforced Clostridial Medium has the typical formula (in $\mathrm{g}^{-1}$ ): yeast extract 3.0; 'Lab-Lemco' powder 10.0; peptone 10.0; soluble starch 1.0; glucose 5.0; cysteine hydrochloride 0.5 ; sodium chloride 5.0; sodium acetate 3.0 ; and agar 0.5 . The medium was autoclaved at $121{ }^{\circ} \mathrm{C}$ and 15 psig for $20 \mathrm{~min}$. A butyric acid medium (BAM) was used in the fermentation study. The BAM was prepared in an 18-liter vessel (Kimax) and consisted of (in $\mathrm{g}$ $1^{-1}$ ): CM-149: 7.0, dextrose: 50-67, and butyric acid: 3-4. The solution of dextrose and CM149 were autoclaved separately to prevent caramelization, a browning reaction, and then blended and sealed shortly after autoclaving to reduce oxygen contamination. After cooling, sterile nitrogen was added to break the vacuum formed during cooling. Butyric acid at 3 to $4 \mathrm{~g} \mathrm{l}^{-1}$ of reagent grade (Aldrich Chemical Co.) and $1 \mathrm{ml}$ of $1 \mathrm{~N} \mathrm{Na}_{2} \mathrm{~S}$ solution were added aseptically via filter membrane. The media in the vessel was kept anaerobic by initially sweeping filtered oxygen-free $\mathrm{N}_{2}$ across the surface and then by continuously keeping a low head pressure using a nitrogen filled elastic bladder, which prevented vacuum formation as the medium was transferred out during the continuous fermentation study. The medium $\mathrm{pH}$ was adjusted between 3.5 and 5.5, depending on the fermentation conditions studied, by adding $12 \mathrm{~N} \mathrm{HCl}$ or $5 \mathrm{~N} \mathrm{NaOH}$.

\section{Fibrous Bed Bioreactor}

Figure A.1 shows the experimental set-up of the continuous FBB system with medium recirculation. The FBB was made of a jacketed glass column (total volume: $800 \mathrm{ml}$ ) packed with a spiral wound fibrous matrix (packed volume: $200 \mathrm{ml}$ ) (12). Before use, the reactor was sterilized at $121^{\circ} \mathrm{C}$ and $15 \mathrm{psig}$ for $30 \mathrm{~min}$, and then cooled to room temperature while purging with sterile filtered nitrogen for one hour to ensure that anaerobic conditions were attained inside the reactor. The reactor was then filled with $700 \mathrm{ml}$ of sterile media containing $20 \mathrm{~g} \mathrm{l}^{-1}$ dextrose. The medium $\mathrm{pH}$ was adjusted to 5.4 using $1 \mathrm{~N} \mathrm{NaOH}$ or $\mathrm{HCl}$, and the reactor temperature was controlled at $35{ }^{\circ} \mathrm{C}$. The medium was continuously circulated at $20-50 \mathrm{ml} / \mathrm{min}$ via a peristaltic pump and flushed with filtered nitrogen to ensure anaerobiosis. The reactor was then inoculated with the cells by injecting $3 \mathrm{ml}$ of a stock culture, and approximately 2-3 days were allowed for cell growth and immobilization in the fibrous matrix. Once solventogenesis occurred, the butyric acid media (BAM) described above was fed into the FBB continuously. 


\section{Fermentation Kinetics Study}

The fermentation kinetics, mainly in solventogenesis phase, was studied with the FBB fed continuously with the butyric acid media (BAM) under strict anaberobiosis. The effects of $\mathrm{pH}$ (3.5 to 5.5) and dilution rate $\left(0.1 \mathrm{~h}^{-1}\right.$ to $\left.1.2 \mathrm{~h}^{-1}\right)$ were studied at $35^{\circ} \mathrm{C}$ with two FBB's. Two fibrous bed bioreactors, reactor $\mathrm{L}$ and $\mathrm{R}$, were used in parallel experiments to ensure the reproducibility of the data. The reactor performance at various dilution rates was first studied at $\mathrm{pH}$ 4.3. The $\mathrm{pH}$ effect was then studied at a fixed dilution rate of $0.6 \mathrm{~h}^{-1}$. For each condition studied, the reactor was operated under a constant feed condition for $\sim 100 \mathrm{~h}$ to allow the reactor to reach pseudo-steady state before changing to next feed condition. The dilution rate was estimated based on the reactor packed volume of $200 \mathrm{ml}$. With continuous medium recirculation and bubbling gas production in the fermentation, the reactor was sufficiently mixed and can be assumed to be well mixed.

\section{Analytical Methods}

At specified time intervals, $1 \mathrm{ml}$ of sample was drawn aseptically. The cell density (data not shown here) in the fermentation broth was measured by optical density (OD) at $600 \mathrm{~nm}$ wavelength with a spectrophotometer (Model 3400, Sequoia-Turner, Mountain View, CA). The pH was measured with a pH/ORP Controller (Model 5652-10, Cole Parmer, Vernon Hills, IL). After removing the bacterial cells by centrifugation at 13,200 rpm $(16,100 \mathrm{~g})$ for $5 \mathrm{~min}$, the clear fermentation broth was subjected to analysis for residual glucose and product concentrations. Glucose concentration was measured using YSI model 2700 Select Biochemistry Analyzer (Yellow Springs, Inc., OH). Acetone, butanol, ethanol, acetic acid and butyric acid were determined by using a gas chromatograph (Varian $3400 \mathrm{GC}$ ) equipped with a flame ionization detector and a SP4270 integrator. The glass column ( $2 \mathrm{~m} \times 2 \mathrm{~mm}$ ) (Supelco Inc., Bellefonte, PA) was packed with $80 / 120$ Carbopack BAW/6.6\% Carbowax 20M. The oven temperature was programmed from $100{ }^{\circ} \mathrm{C}$ to $185{ }^{\circ} \mathrm{C}$ at a rate of $15{ }^{\circ} \mathrm{C} / \mathrm{min}$ after an initial holding time of one minute. The injector and detector temperatures were set at $200{ }^{\circ} \mathrm{C}$ and $225{ }^{\circ} \mathrm{C}$, respectively. Nitrogen was the carrier gas set at a flow rate of $20 \mathrm{ml} / \mathrm{min}$.

\section{Results}

\section{Effects of Dilution Rate}

Figure A.2 shows the concentration profiles of the outlet streams from the reactors operated at various dilution rates with the feed medium at $\mathrm{pH}$ 4.3. After the initial growth phase and the feed medium had been changed to BAM, the reactor L was operated by gradually increasing the dilution rate from $0.1 \mathrm{~h}^{-1}$ to $0.3 \mathrm{~h}^{-1}$ at $102 \mathrm{~h}$, to $0.5 \mathrm{~h}^{-1}$ at $201 \mathrm{~h}$, and to $1.0 \mathrm{~h}^{-1}$ at $311 \mathrm{~h}$; and then dropped to $0.8 \mathrm{~h}^{-1}$ at $407 \mathrm{~h}$ before increasing again to $1.2 \mathrm{~h}^{-1}$ at $503 \mathrm{~h}$. In contrast, the reactor $\mathrm{R}$ was initially operated at $0.9 \mathrm{~h}^{-1}$ and then gradually decreased to $0.6 \mathrm{~h}^{-1}$ at $109 \mathrm{~h}$, to $0.4 \mathrm{~h}^{-1}$ at 205 $\mathrm{h}$, and to $0.2 \mathrm{~h}^{-1}$ at $301 \mathrm{~h}$. The dilution rate was then increased to $0.7 \mathrm{~h}^{-1}$ at $407 \mathrm{~h}$ and again to 1.1 $\mathrm{h}^{-1}$ at $500 \mathrm{~h}$. As can be seen in the figure, the outlet concentrations of substrates and products changed as the dilution rate changed, and in general they fluctuated before approaching a pseudo-steady state towards the end of each operating condition period.

Although a clear steady state was not always achieved, there were clear trends in solvents production and substrates utilization as affected by the dilution rate. In general, as the dilution rate increased from 0.1 to $1.2 \mathrm{~h}^{-1}$, the outlet concentrations of glucose, butyrate, and acetate also increased, whereas the concentrations of acetone, ethanol and butanol decreased (Reactor L). Consistent trends in reactor responses to decreasing the dilution rate were also observed (Reactor 
R). These were expected results since at a higher dilution rate, the medium had shorter contact time with cells and, therefore, less substrates were consumed with less products formed in the fermentation. The highest concentration of butanol produced in the fermentation was $12.5 \mathrm{~g}^{-1}$ at the dilution rate of $0.1 \mathrm{~h}^{-1}$, whereas a low butanol concentration of $\sim 3.5 \mathrm{~g} \mathrm{l}^{-1}$ was obtained at higher dilution rates of $0.8-1.2 \mathrm{~h}^{-1}$. It should be noted that the butyrate concentration in the reactor outlet was always lower than that in the BAM, indicating that butyrate also was used as a carbon source in the solventogenic fermentation. However, a significant amount of acetate was still produced in the fermentation, especially at high dilution rates when there was significant cell growth or acidogenesis. As the dilution rate decreased, acetate concentration also decreased because the acetate produced in acidogenesis was re-consumed in solventogenesis.

The reactor volumetric productivities and product yields at $\mathrm{pH} 4.3$ and various dilution rates were estimated based on the time course data in the pseudo-steady state, and are shown in Figure A.3. In general, production rates for butanol and acetate increased with increasing the dilution rate from 0.1 to $1.2 \mathrm{~h}^{-1}$, whereas acetone and ethanol remained relatively unaffected by the dilution rate except at $0.1 \mathrm{~h}^{-1}$. The maximum butanol productivity of $4.6 \mathrm{~g}^{-1} \mathrm{~h}^{-1}$ at $0.9 \mathrm{~h}^{-1}$ dilution rate was obtained with Reactor $\mathrm{R}$ at the beginning of the solventogenic fermentation, while a lower productivity of $\sim 3.3 \mathrm{~g} \mathrm{l}^{-1} \mathrm{~h}^{-1}$ at higher dilution rates was obtained after the reactor had been operated for a long period. It is not clear if the large difference was attributed to the dilution rate effect or the culture age. Butanol is a strong inhibitor to the fermentation. It is thus expected to have a lower butanol productivity at a lower dilution rate where the butanol concentration was higher. The increased acetate productivity by increasing the dilution rate was consistent with the higher cell growth rate as acetate and butyrate are the main products in the acidogenic phase where cell growth also occurs.

The product yields from glucose in the fermentation were based on the total consumption of glucose and butyrate, and each gram of butyric acid consumed was considered as two grams of glucose in the feed since the butyric acid yield from glucose in butyric acid fermentation was $\sim 50 \%$ (12). As can be seen in Figure $3 \mathrm{~B}$ at $\mathrm{pH} 4.3$, the butanol yield decreased slightly as the dilution rate increased from 0.1 to $0.3 \mathrm{~h}^{-1}$, but then increased with increasing the dilution rate until reaching the maximum value of $0.42 \mathrm{~g} \mathrm{~g}^{-1}$ at $0.9 \mathrm{~h}^{-1}$. The butanol yield was lower as the dilution rate continued to increase to $1.2 \mathrm{~h}^{-1}$. In contrast, acetone and ethanol yields appeared to be not significantly affected by the dilution rate. The overall yield of solvents (acetone, butanol, and ethanol) was $\sim 0.4 \mathrm{~g} \mathrm{~g}^{-1}$, with the maximum value of $0.53 \mathrm{~g} \mathrm{~g}^{-1}$ obtained at $1.0 \mathrm{~h}^{-1}$. The average product yields at all dilution rates studied were found to be $0.27,0.12$, and $0.015 \mathrm{~g} \mathrm{~g}^{-1}$ for butanol, acetone, and ethanol, respectively.

\section{Effects of pH}

After $606 \mathrm{~h}$, the dilution rate in the reactor $\mathrm{L}$ was decreased from 1.2 to $0.6 \mathrm{~h}^{-1}$. When the $\mathrm{pH}$ was adjusted to 3.5 at $623 \mathrm{~h}$, the concentrations of acetone, butanol and ethanol decreased dramatically and reduced to almost $0 \mathrm{~g} \mathrm{l}^{-1}$ by $700 \mathrm{~h}$ (see Figure A.4A). In the mean time, the concentrations of glucose and butyric acid increased with time to reach almost their feed concentrations. Coupling with the low OD value, it was apparent that the fermentation had almost ceased at this low $\mathrm{pH}$ value. However, the trends were reversed and the reactor started to recover after the feed $\mathrm{pH}$ was increased to 3.8 at $726 \mathrm{~h}$. The product concentrations (ABE) continued to increase while substrates decreased as the feed $\mathrm{pH}$ was increased to 4.0 at $887 \mathrm{~h}$. For reactor $\mathrm{R}$, after reducing the dilution rate from 1.1 to $0.6 \mathrm{~h}^{-1}$ and increasing the feed $\mathrm{pH}$ from 
4.3 to 5.3 at $661 \mathrm{~h}$, the concentration of butanol increased rapidly and the concentrations of glucose and butyrate reduced (see Figure A.4B). This trend appeared to continue with time, although slowed down as the $\mathrm{pH}$ changed to 4.7 at $733 \mathrm{~h}$, despite that the $\mathrm{pH}$ decreased to 4.5 at $795 \mathrm{~h}$ and then increased to 5.1 at $901 \mathrm{~h}$, reaching a significantly higher butanol concentration of $\sim 7.7 \mathrm{~g} \mathrm{l}^{-1}$ at $956 \mathrm{~h}$. The observed effects probably were mainly attributed to the change in the dilution rate and much less to the $\mathrm{pH}$ in the range studied (4.5 to 5.3). However, further increasing the feed $\mathrm{pH}$ to 5.5 at $1028 \mathrm{~h}$ abruptly decreased butanol production in the fermentation and the concentration of butanol dropped to below $4 \mathrm{~g} \mathrm{l}^{-1}$, with corresponding increase in the glucose concentration. For both reactors, the concentration of acetic acid appeared to increase somewhat with increasing the $\mathrm{pH}$, consistent with the fact that acidogenesis is generally favored at a higher $\mathrm{pH}$.

Although steady state might have not been reached in certain operating $\mathrm{pH}$ conditions studied, the productivities and product yields at the dilution rate of $0.6 \mathrm{~h}^{-1}$ and various feed $\mathrm{pH}$ values were estimated and are shown in Figure A.5. In general, the reactor productivity for butanol increased with increasing the $\mathrm{pH}$ until reaching the maximum value of $4.6 \mathrm{~g}^{-1} \mathrm{~h}^{-1}$ at $\mathrm{pH} 5.1$, but then decreased as the $\mathrm{pH}$ increased further to 5.5. The effect of $\mathrm{pH}$ on the butanol yield appeared to be small in the range of 3.8 to 5.3, although the maximum value was found at $\mathrm{pH} 4.5$. Butanol yield was significantly lower at $\mathrm{pH} 5.5$, which is usually considered to be the $\mathrm{pH}$ value more favorable to acidogenesis. Both the productivity and butanol yield were low at $\mathrm{pH} 3.5$, which appeared to be the lower limit for $\mathrm{ABE}$ fermentation. Acetone and ethanol production appeared to be much less sensitive to the $\mathrm{pH}$ in the range studied.

\section{Discussion}

Optimizing the ABE fermentation process has long been the aspiration of over a century of research. Conventionally, the profitability of fermentation is influenced by the type and concentration of substrate, the dilution rate, $\mathrm{pH}$, culture medium and product recovery. Even using cell recycle, cell immobilization or extractive fermentation to increase cell density and productivity, the yield of the combined ABE production never exceeded $0.44 \mathrm{~g} \mathrm{~g}^{-1}$ (13-15).

The production of butanol is usually associated with the uptake of various acids. In this work, we developed a continuous fermentation that improved the uptake of butyric acid and glucose by $C$. acetobutylicum in the FBB. Producing butanol via butyric acid converted from carbohydrates was efficient owing to the high density of viable cells maintained in the FBB through continual cell renewal (16). The optimal butanol yield of $0.42 \mathrm{~g} \mathrm{~g}^{-1}$ and productivity of $4.6 \mathrm{~g} \mathrm{l}^{-1} \mathrm{~h}^{-1}$ were obtained in a 200-ml FBB at the dilution rate of $0.9 \mathrm{~h}^{-1}, \mathrm{pH} 4.3$, and $35^{\circ} \mathrm{C}$ with $54 \mathrm{~g} \mathrm{l}^{-1}$ glucose and $3.6 \mathrm{~g} \mathrm{l}^{-1}$ butyric acid in the feed stream. The concentration of butanol was $5.1 \mathrm{~g} \mathrm{l}^{-1}$ on average. The conversions of glucose and butyric acid were 0.19 and 0.31 , respectively. The optimum solvent (ABE) yield was $0.53 \mathrm{~g} \mathrm{~g}^{-1}$ under the same process condition.

The higher butanol and total solvent yields obtained in this work can be attributed to feeding with butyrate as a co-substrate (BAM), which greatly reduced acidogenesis and promoted solventogenesis. The increased butanol yield also could be due to the dramatically reduced ethanol production. Also, cell immobilization in the FBB allowed the bacteria to survive long in the solventogenic phase, allowing for long-term continuous solvent production without frequent cell regeneration. . 
This work has shown that doubling the yield of butanol to $\sim 2.5 \mathrm{gal} / \mathrm{bushel}$ of corn $(0.37 \mathrm{~L} / \mathrm{kg})$ in the conventional $\mathrm{ABE}$ fermentation can be achieved by converting carbohydrates into mainly butanol, which can make fermentation derived butanol economically competitive with petrochemically derived butanol. Compared to the conventional ABE fermentation (the optimum butanol yield of $0.25 \mathrm{~g} \mathrm{~g}^{-1}$ and productivity of $4.5 \mathrm{~g} \mathrm{l}^{-1} \mathrm{~h}^{-1}$ ), the FBB notably enhanced the yield of butanol and ABE (more than 68 and 20\%, respectively) by C. acetobutylicum, making butanol production from renewable resource an attractive alternative to ethanol fermentation. Commercialization of this new technology has the propensity to reduce our Nation's dependence on foreign oil, protect our fuel generation grid from sudden disruption, develop our agricultural base, solve the hydrogen supply problem associated with fuel cells, and help reduce global warming.

\section{References}

Minton, N. P. and Clarke, D. J. (1989), Clostridia, Plenum Press, New York.

Soni, B. K., Soucaille P., and Goma, G. (1987), Appl. Microbiol. Biotechnol., 25, 317-321.

Garcia, A., Ianotti, E. L., Fischer, J. L. (1986), Biotechnol. Bioeng., 28, 785-791.

Durre, P. (1998), Appl. Microbiol. Biotechol., 49, 639-648.

Mollah, A. H. and Stuckey, D. C. (1993), J. Chem. Tech. Biotechnol., 56, 83-89.

Qureshi, N., Schripsema, J., Lienhardt, J., and Blaschek, H. P. (2000), World J. Microbiol. Biotechnol., 16(4), 377-382.

Huang, J. and Meagher, M. M. (2001), J. Membrane Sci., 192, 231-242.

Mollah, A. H. and Stuckey, D. C. (1993), Enzyme Microb. Technol., 15, 200-207.

Ladisch, M. R. (1991), Enzyme Micorb. Technol., 13, 280-283.

Park, C.-H., Okos, M. R., and Wankat P. C. (1989), Biotechnol. Bioeng., 34, 18-29

Qureshi, N. and Blaschek, H. P. (1999), Biotechnol. Prog., 15, 594-602.

Zhu, Y., Wu, Z., and Yang, S.-T. (2002), Process Biochem., 38(5), 657-666.

Qureshi, N., Maddox, I.S., and Friedl, A. (1992), Biotechnol. Prog., 8, 382-390.

Qureshi, N. and Blaschek, H.P. (2000), Appl. Microbiol. Biotechol., 84-86, 225-235.

Qureshi, N. and Blaschek, H.P. (2001), Renewable Energy, 22, 557-564.

Zhu, Y. and Yang, S.-T. (2003), Biotechnol. Prog., 19, 365-372. 


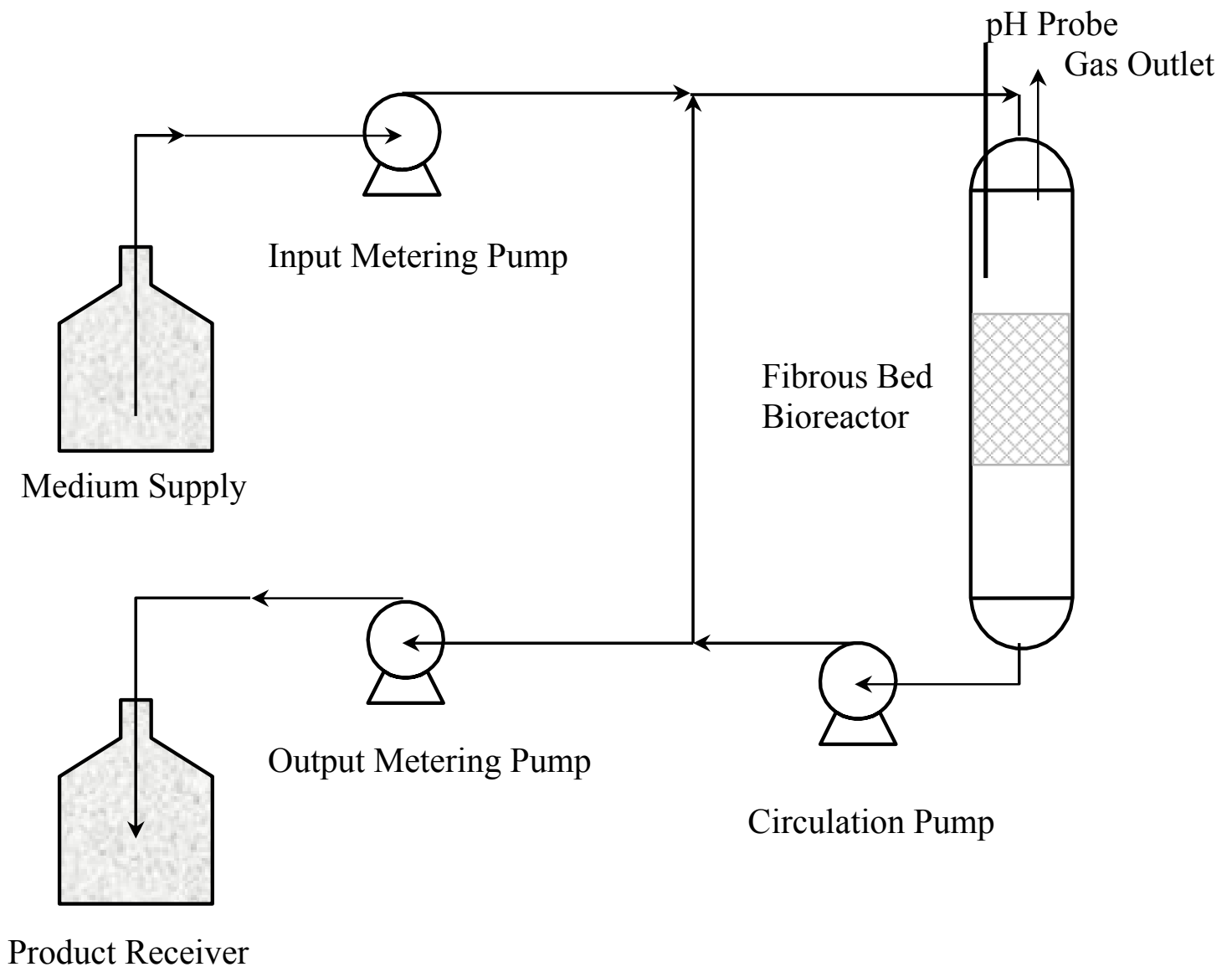

Figure A.1. A continuous fibrous bed bioreactor (FBB) system for ABE fermentation. 


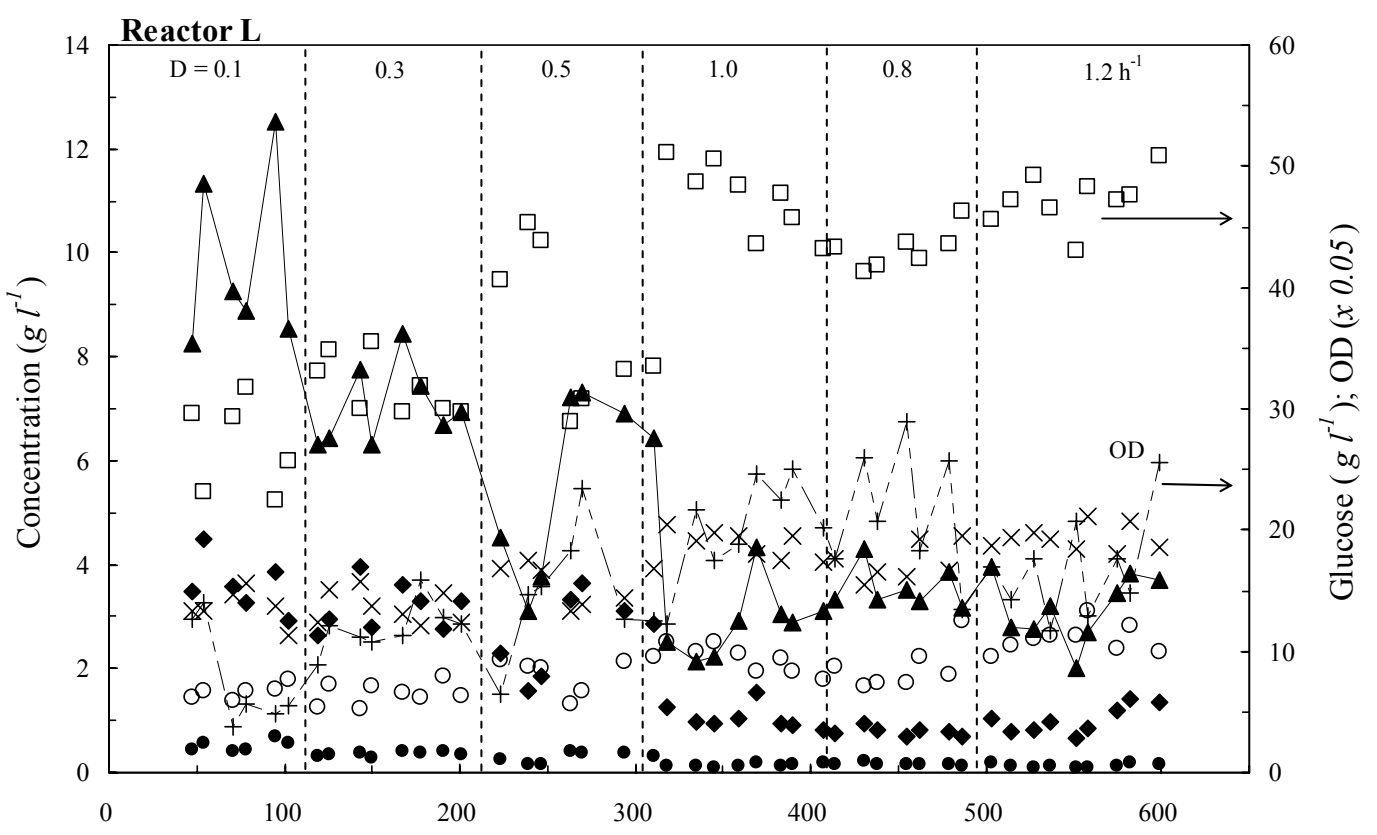

A

Time $(h)$

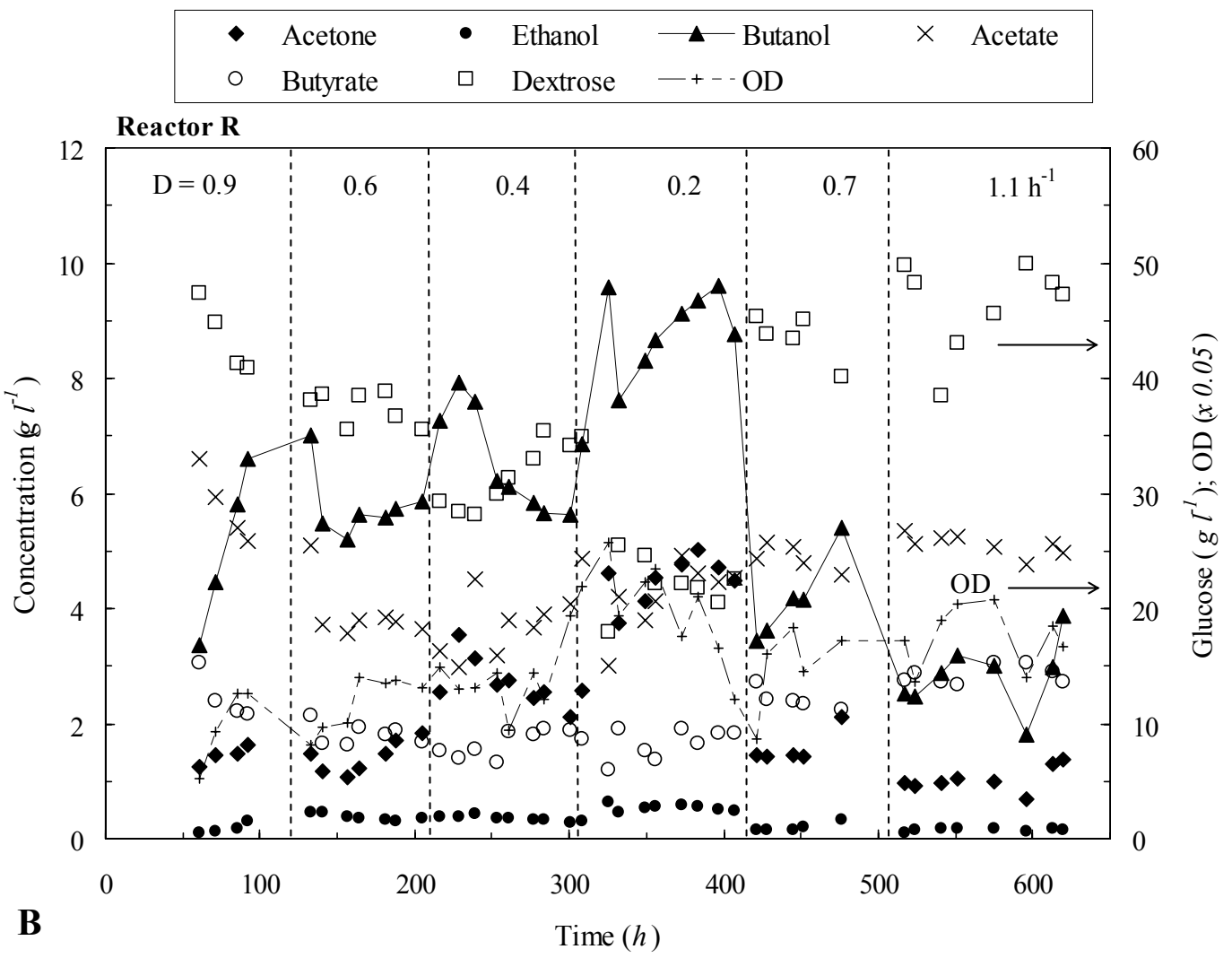

Figure A.2. Kinetics of continuous $\mathrm{ABE}$ fermentation at various dilution rates and $\mathrm{pH}$ 4.3. Glucose and OD are on the right axis; others are on the left axis. 

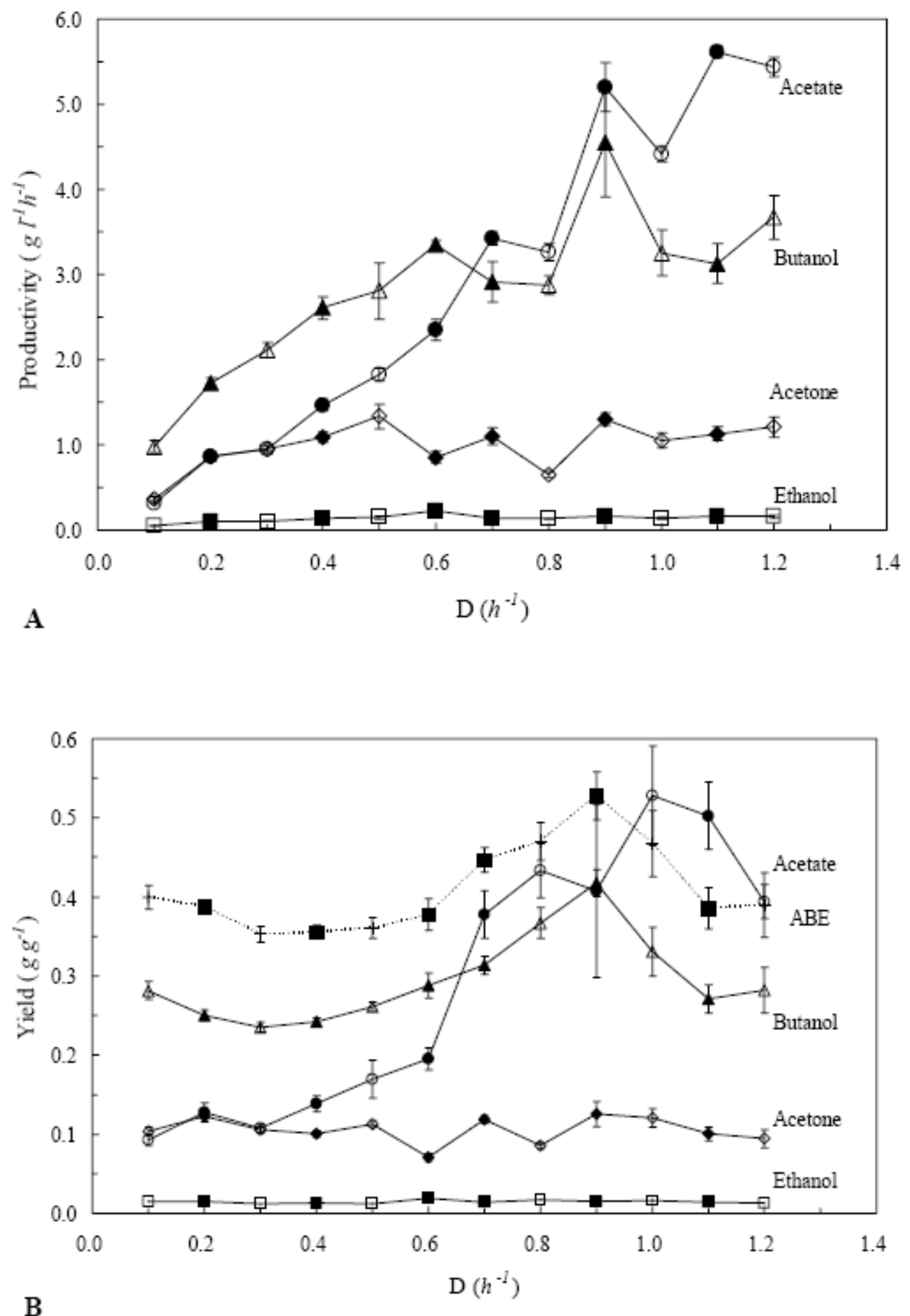

Figure A.3. Effects of dilution rate on productivities and product yields at $\mathrm{pH} 4.3$. Hollow symbols: Reactor L; Filled symbols: Reactor R. 

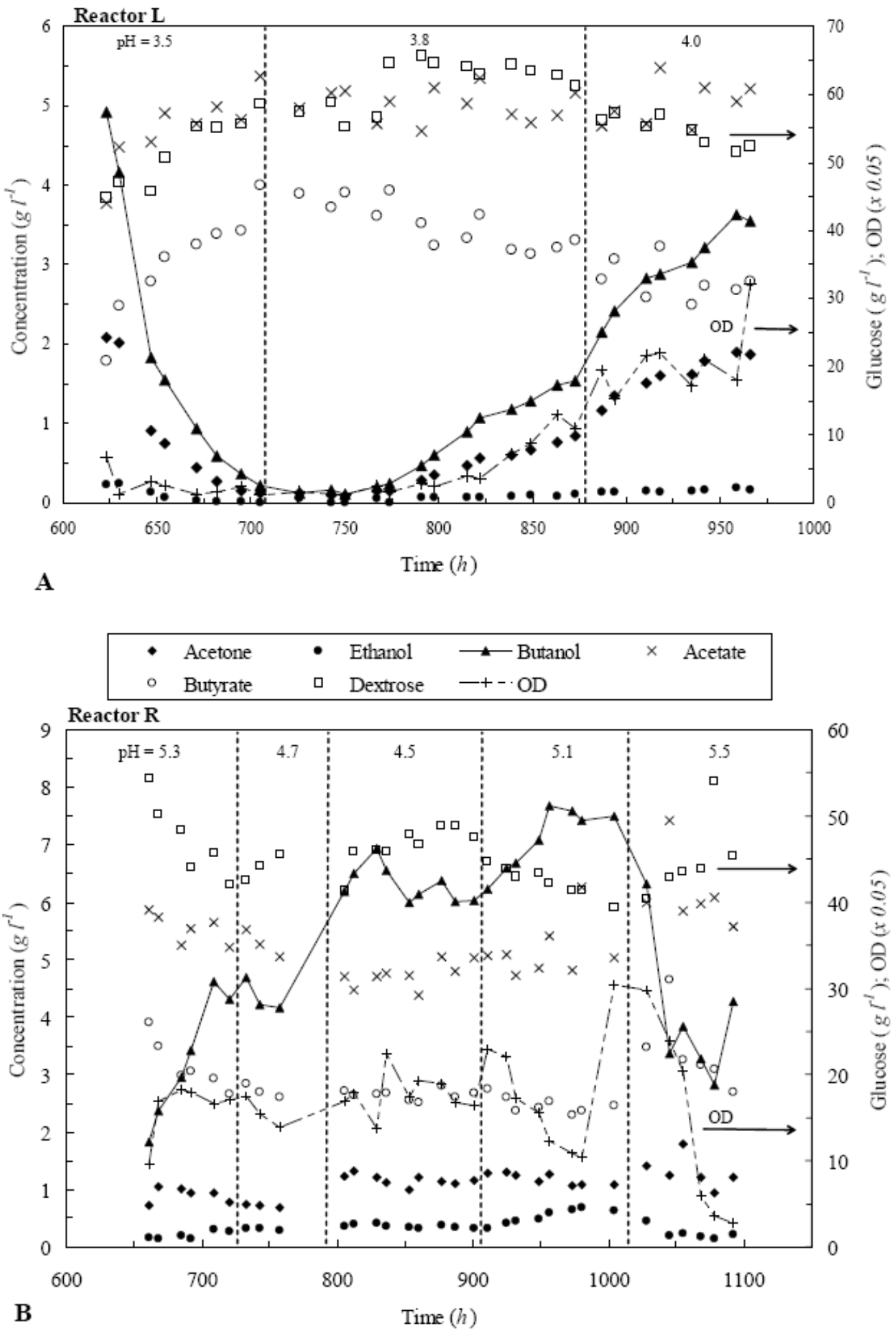

Figure A.4. Kinetics of continuous ABE fermentation at various $\mathrm{pH}$ values and $0.6 \mathrm{~h}^{-1}$ dilution rate. Glucose and OD are on the right axis; others are on the left axis. 

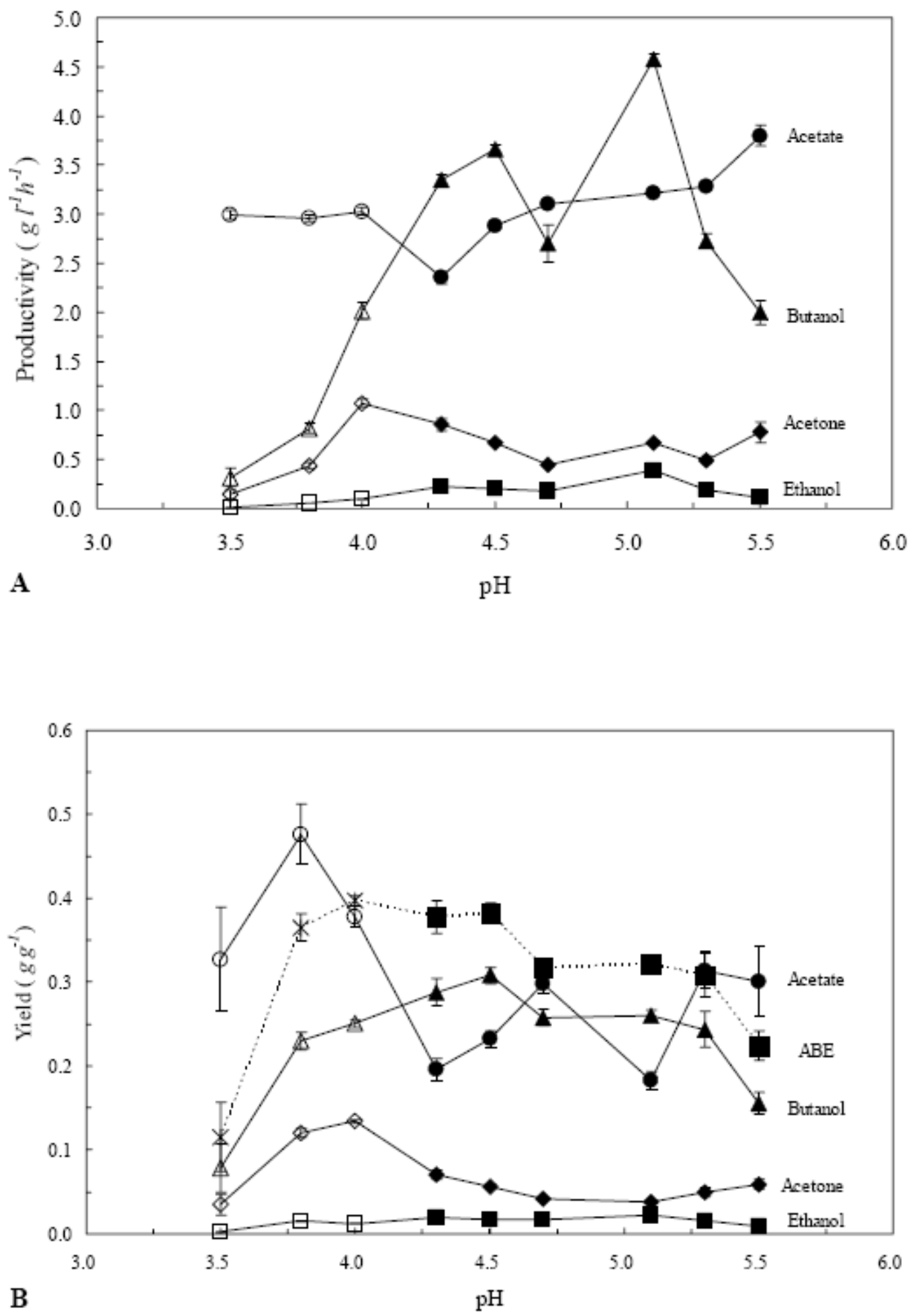

Figure A.5. Effects of $\mathrm{pH}$ on productivities and product yields at $\mathrm{D}=0.6 \mathrm{~h}^{-1}$. Hollow symbols: Reactor L; Filled symbols: Reactor R. 


\section{B. Development of butyric acid over-producing strains}

The metabolic pathway of glucose in acidogenic Clostridium tyrobutyricum has several possible end-products, including butyrate, and acetate, $\mathrm{CO}_{2}, \mathrm{H}_{2}$ and lactate as byproducts. Two analogous pathways lead to the formation of acetate and butyrate, with acetyl-CoA and butyryl-CoA functioning as key intermediates, respectively. First, acetyl phosphate and butyryl phosphate are produced from their CoA derivatives, catalyzed by phosphotransacetylase (PTA) and phosphotransbutyrylase (PTB), respectively. Then, these acyl phosphates are converted to acetate and butyrate catalyzed by acetate kinase (AK) and butyrate kinase (BK), respectively. Fermentation studies have shown that the major characteristic of this fermentation is the concomitant production of acetate with butyrate. In addition to $0.95 \mathrm{~mol} / \mathrm{mol}$ of butyrate production from glucose, a high amount of $0.27 \mathrm{~mol} / \mathrm{mol}$ of acetate was also formed in the immobilized cell fermentation. This situation raises the physiological question of redirecting carbon flow between the pathways involved in order to improve the selectivity of butyrate production over acetate.

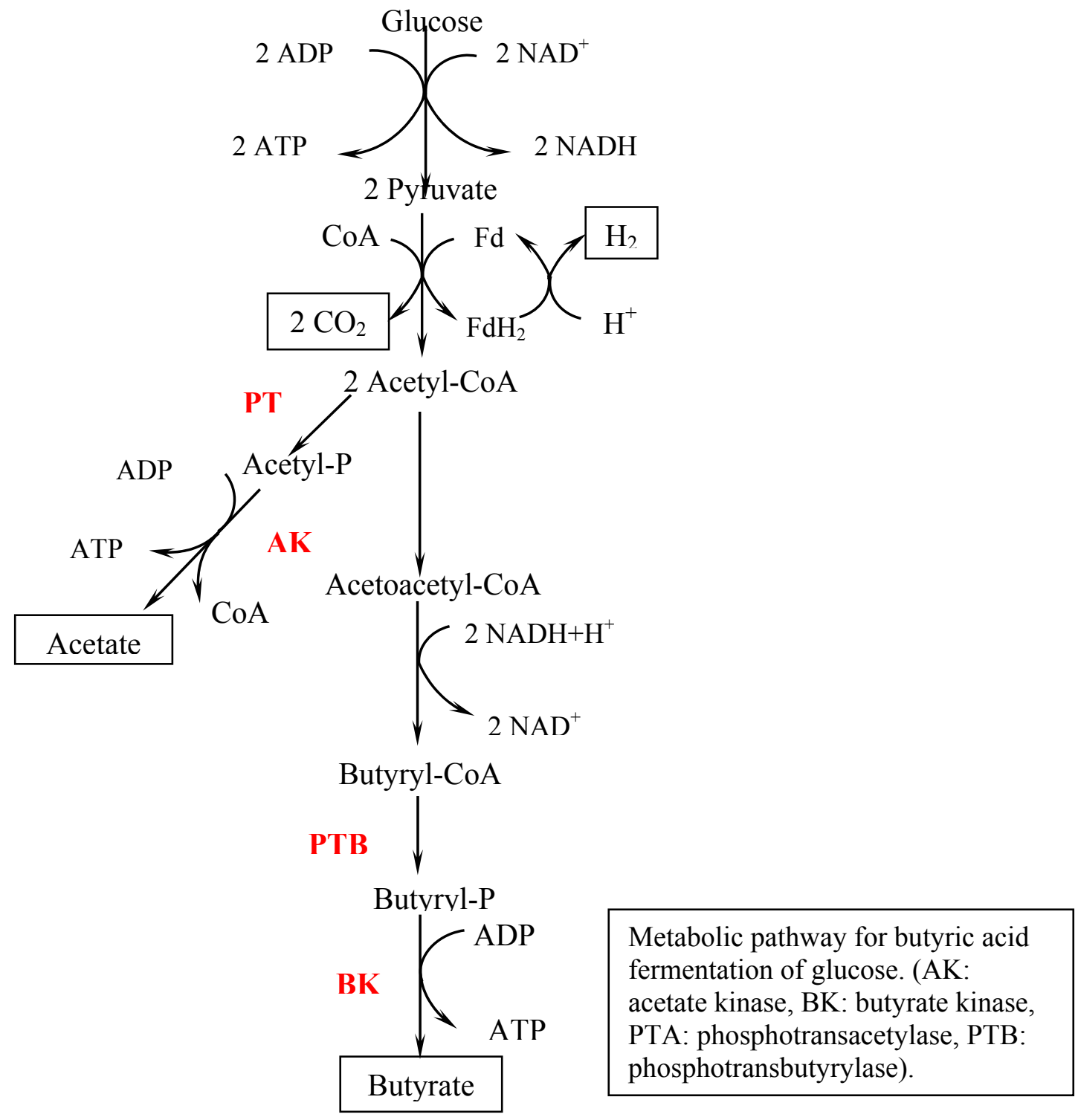


Based on the fermentation biochemistry, stoichiometric equations have been derived for fermentations of glucose and xylose by $C$. tyrobutyricum. It is clear that butyrate yield can be increased significantly by reducing biomass formation and acetate production. The butyrate yields can be increased to more than $1 \mathrm{~mol} / \mathrm{mol}$ for glucose and $0.83 \mathrm{~mol} / \mathrm{mol}$ for xylose as the substrate for immobilized cell fermentation when acetate formation is completely eliminated.

The objectives of this study were to: (1) genetically modify cellular metabolism by using recombinant DNA technology in order to produce more butyrate and reduce or eliminate acetate formation, (2) investigate the impact of down-regulating acetate formation enzymes in the metabolism of $C$. tyrobutyricum, (3) develop new strains of $C$. tyrobutyricum exhibiting significantly enhanced butyrate production capacities for industrial applications. We focused on the genes ack and pta encoding enzymes AK and PTA involved in the acetate formation pathway. Gene knockout experiments were carried out to develop butyric acid over-producing strains, and the results have been published (Biotechnol. Bioeng., 90:154-166, 2005) and are discussed in the following section.

\title{
B1. Construction and Characterization of pta Gene Deleted Mutant of Clostridium tyrobutyricum for Enhanced Butyric Acid Fermentation
}

\begin{abstract}
Clostridium tyrobutyricum ATCC 25755 is an acidogenic bacterium, producing butyrate and acetate as its main fermentation products. In order to decrease acetate and increase butyrate production, integrational mutagenesis was used to disrupt gene associated with the acetate formation pathway in $C$. tyrobutyricum. A non-replicative integrational plasmid containing phosphotransacetylase gene ( $p t a)$ fragment cloned from $C$. tyrobutyricum by using degenerate primers and an erythromycin resistance cassette was constructed and introduced into $C$. tyrobutyricum by electroporation. Integration of the plasmid into the homologous region on the chromosome inactivated the target pta gene and produced the pta-deleted mutant (PPTA-Em), which was confirmed by Southern hybridization. SDS-PAGE and two-dimensional protein electrophoresis results indicated that protein expressions were changed in the mutant. Enzyme activity assays using the cell lysate showed that the activities of PTA and AK in the mutant were reduced by more than $60 \%$ for PTA and $80 \%$ for AK. The mutant grew slower in batch fermentation with glucose as the substrate, but produced $15 \%$ more butyrate and $14 \%$ less acetate as compared to the wild type strain. Its butyrate productivity was approximately two fold higher than the wild type strain. Moreover, the mutant showed much higher tolerance to butyrate inhibition and the final butyrate concentration was improved by $68 \%$. However, inactivation of pta gene did not completely eliminate acetate production in the fermentation, suggesting the existence of other enzymes (or pathways) also leading to acetate formation. This is the first reported genetic engineering study demonstrating the feasibility of using gene inactivation technique to manipulate the acetic acid formation pathway in $C$. tyrobutyricum in order to improve butyric acid production from glucose.
\end{abstract}




\section{INTRODUCTION}

Clostridium tyrobutyricum ATCC 25755 is a gram-positive, rod-shaped, spore-forming, obligate anaerobic bacterium capable of fermenting a wide variety of carbohydrates to butyric and acetic acids. There has been increasing interest in the production of butyric acid from agricultural commodities and processing wastes using C. tyrobutyricum (Zhu et al., 2002). Butyric acid has many applications in chemical, food, and pharmaceutical industries (Zigova, et al. 1999; Vandak et al. 1997). Conventional butyric acid fermentation process is not yet economically competitive because it produces butyric acid at a relatively low concentration, yield and rate. Recently, $C$. tyrobutyricum cells immobilized in a fibrous-bed bioreactor were successfully used for butyrate fermentation with increased reactor productivity and final product concentration (Zhu et al., 2002; Wu and Yang, 2003). However, the butyrate yield was only $\sim 0.5 \mathrm{~g} / \mathrm{g}$ or $0.9 \mathrm{~mol} / \mathrm{mol}$ and acetate yield was $\sim 0.27 \mathrm{~mol} / \mathrm{mol}$ of glucose fermented in the fermentation (Zhu et al., 2002). To improve the economics of the fermentation process, it is desirable to increase butyrate production while reducing acetate production, which also reduces the product separation cost. Several factors influencing the selectivity for butyrate over acetate in the fermentation have been identified, including cell growth rate, glucose concentration or supply mode, and the partial pressure of $\mathrm{H}_{2}$ (van der Lelie, et al., 1988; Michel-Savin, et al., 1990; Michel-Savin, et al., 1990). Complete selectivity for butyrate production was shown to be possible in glucose-limited fedbatch cultures (Michel-Savin, et al., 1990), but the reactor productivity and final product concentration were not high enough for economical production purpose.

The metabolic pathways for acids production in some clostridial strains, such as Clostridium acetobutylicum, have been extensively studied (Rogers and Gottschalk, 1993). The breakdown of hexose to pyruvate proceeds via the Embden-Meyerhof-Parnas pathway in $C$. acetobutylicum. Phosphotransacetylase (PTA) and acetate kinase (AK) are two key enzymes involved in the pathway leading to acetic acid formation, whereas phosphotransbutyrylase (PTB) and butyrate kinase (BK) catalyze the formation of butyric acid from butyryl-CoA. $C$. tyrobutyricum produces butyrate with acetate as its main co-product, indicating similar acids formation metabolic pathways possibly exist in this bacterium. The detection of enzyme activities of PTA, AK, PTB, and BK in C. tyrobutyricum demonstrates that the production of butyrate and acetate can also be catalyzed by these enzymes (Zhu and Yang, 2003).

Integrational mutagenesis, a genetic engineering technique that can selectively inactivate undesired genes from the host chromosome has been developed and successfully used to create metabolically engineered mutants of Clostridial strains (Green et al., 1996). In this technique, a fragment of the target gene is cloned into a non-replicative vector with a selection marker, resulting in the non-replicative integrational plasmid. The partial gene in the non-replicative plasmid can recombine with the internal homologous region of the original target gene in the parental chromosome, which results in insertional inactivation of the target gene. Previous studies using integrational mutagenesis to improve clostridial fermentation product yield have focused on solventogenic C. acetobutylicum. A non-replicative plasmid (pJC4) with partial pta gene (encoding PTA) was constructed and integrated into the homologous region of pta gene on the chromosome of $C$. acetobutylicum ATCC 824, resulting in reduced PTA and AK activities and acetate production (Green and Bennett, 1998; Green et al., 1996). The same metabolic engineering approach can be used to reduce or eliminate acetate production in butyric acid fermentation by C. tyrobutyricum.

The main objectives of this study were to genetically modify the acetate formation pathway by inactivating pta gene in C. tyrobutyricum and to study its effect on butyric acid 
fermentation. The pta gene has been cloned and characterized for several microorganisms, including C. acetobutylicum (Boynton, et al., 1996), Escherichia coli (Kakuda et al., 1994; Matsuyama, et al., 1989), and Methanosarcina thermophila (Latimer and Fery, 1993). However, to date no genetic engineering study has been reported for C. tyrobutyricum or similar butyric acid bacteria, and very little is known about the pta gene in C. tyrobutyricum. In this work, the partial pta gene from C. tyrobutyricum was cloned and sequenced. Gene inactivation by integrational plasmid was then carried out to develop a pta-deleted mutant. The protein expressions and the enzyme activities of the mutant were examined to understand how the gene manipulation worked. Finally, the effects of the mutation on cell growth and fermentation kinetics were studied and are discussed in this paper.

\section{MATERIALS AND METHODS}

\section{Bacterial Strains and Plasmids}

Table 1 lists all bacterial strains and plasmids used or created in this work along with their characteristics and sources. C. tyrobutyricum ATCC 25755, designated as the wild type, was grown anaerobically at $37^{\circ} \mathrm{C}$ in clostridial growth medium (CGM) (Huang et al., 1998). Colonies were maintained on Reinforced Clostridial Medium (RCM; Difco) plates in the anaerobic chamber. These media were supplemented with $40 \mu \mathrm{g} / \mathrm{ml}$ erythromycin (Em) for $C$. tyrobutyricum mutant selection. E. coli was grown aerobically at $37^{\circ} \mathrm{C}$ in Luria-Bertani (LB) medium supplemented with ampicillin $(100 \mu \mathrm{g} / \mathrm{ml})$ and erythromycin $(200 \mu \mathrm{g} / \mathrm{ml})$.

\section{DNA Manipulations}

Plasmid DNA from E. coli was isolated using QIAprep Miniprep plasmid purification kit (Qiagen, Valencia, CA) for sequencing and transformation purposes. Chromosomal DNA from C. tyrobutyricum was prepared using QIAGEN genomic DNA kit. DNA fragment was purified from gel using QIAGEN gel extraction kit.

PCR Amplification. Synthetic oligonucleotides were designed as primers for PCR amplification based on the homology alignment analysis of PTA from E. coli, C. acetobutylicum, B. subtilis, M. thermophila, P. denitrificans, and Mycoplasma genitalium (Boynton et al., 1996) and the codon usage preference for $C$. tyrobutyricum (http://www.kazusa.or.jp/codon). The highest homologous region of the amino acid sequence was selected as the degenerate primers. The DNA sequences of the non-specific primers for pta gene were 5'-GA(A/G) $(\mathrm{C} / \mathrm{T}) \mathrm{T}(\mathrm{A} / \mathrm{T} / \mathrm{G})$ $\mathrm{AG}(\mathrm{A} / \mathrm{G}) \mathrm{AA}(\mathrm{A} / \mathrm{G}) \mathrm{CA}(\mathrm{T} / \mathrm{C}) \mathrm{AA}(\mathrm{A} / \mathrm{G}) \mathrm{GG}(\mathrm{A} / \mathrm{T}) \mathrm{ATG} \mathrm{AC}-3^{\prime}$ ' (upstream) and 5'-(A/T)GC CTG $(\mathrm{A} / \mathrm{T})(\mathrm{G} / \mathrm{A}) \mathrm{C}(\mathrm{A} / \mathrm{T}) \mathrm{GC}(\mathrm{A} / \mathrm{T} / \mathrm{C}) \mathrm{GT}(\mathrm{A} / \mathrm{T}) \mathrm{AT}(\mathrm{A} / \mathrm{T}) \mathrm{GC}-3$ ' (downstream). Amplification of partial pta sequence from wild type C. tyrobutyricum chromosomal DNA (template) was performed with optimized PCR buffer containing $0.5 \mathrm{mM}$ (each) dNTPs, $300 \mathrm{nM}$ (each) primers, $2.5 \mathrm{mM}$ $\mathrm{MgCl}_{2}$ and $2.5 \mathrm{U}$ Taq DNA polymerase (Invitrogen, Carlsbad, CA) in a DNA engine (MJ Research, Reno, NV). Thermal cycling was conducted under the following conditions: initial denaturation $\left(94^{\circ} \mathrm{C}\right.$ for $\left.3 \mathrm{~min}\right) ; 40$ cycles program with template denaturation $\left(94^{\circ} \mathrm{C}\right.$ for $\left.50 \mathrm{~s}\right)$, primers annealing $\left(48^{\circ} \mathrm{C}\right.$ for $\left.50 \mathrm{~s}\right)$, and extension $\left(72^{\circ} \mathrm{C}\right.$ for $\left.1 \mathrm{~min}\right)$; deoxyadenosine (A) adding to the $3^{\prime}$ ends of PCR products $\left(72^{\circ} \mathrm{C}\right.$ for $\left.10 \mathrm{~min}\right)$. The PCR product with expected size of $730 \mathrm{bp}$ was cloned into PCR vector pCR $2.1(3.9 \mathrm{~kb})$ using TA cloning kit (Invitrogen), and the produced plasmid pCR-PTA $(4.65 \mathrm{~kb})$ was then sequenced to determine the DNA sequence of the cloned pta gene fragment.

Construction of Integrational Plasmid. Fig. B.1 shows the general design in constructing the integrational plasmid pPTA-Em. First, a 1.5-kb fragment was removed from pCR-PTA (4.65 
$\mathrm{kb})$ with $S p h \mathrm{I}$ digestion, and the remaining pCR-PTA was religated to form plasmid pCR-PTA1 $(3.15 \mathrm{~kb})$. Then, a 1.6-kb HindIII fragment containing the $\mathrm{Em}^{\mathrm{r}}$ cassette from pDG 647 (GuéroutFleury et al., 1995) was ligated with HindIII digested pCR-PTA1, forming the integrational plasmid pPTA-Em $(4.75 \mathrm{~kb})$ for use in pta gene inactivation.

\section{Transformation}

Plasmid transformation to E. coli was performed according to the manufacturer's instruction (Invitrogen). Transformation of integrational plasmid into C. tyrobutyricum was carried out using a Bio-Rad Gene pulser (Model II). All manipulations were operated in an anaerobic chamber equipped with an incubator and a centrifuge. The competent cells of C. tyrobutyricum were prepared as follows: after overnight growth, a $50 \mathrm{ml}$ culture at late log-growth phase was used to inoculate $40 \mathrm{ml} \mathrm{CGM}$ medium supplied with $40 \mathrm{mM}$ DL-threonine. Cells were grown for $4 \mathrm{~h}\left(\mathrm{OD}_{600}=\sim 0.8\right)$, harvested, washed twice and suspended in ice-cold electroporation buffer, referred as SMP buffer ( $270 \mathrm{mM}$ sucrose, $1 \mathrm{mM} \mathrm{MgCl}_{2}, 7 \mathrm{mM}$ sodium phosphate, $\mathrm{pH}$ 7.4). About $0.5 \mathrm{ml}$ of cell suspension was chilled on ice for $5 \mathrm{~min}$ in a $0.4-\mathrm{cm}$ electroporation cuvette (Bio-Rad, Hercules, CA), and plasmid DNA (10 15 $\mu \mathrm{g}$ of non-replicative plasmid pPTA-Em) was added into the cold competent cell suspension. After the pulse $(2.5 \mathrm{kV}, 600 \Omega, 25 \mu \mathrm{F})$ was applied to the cuvette, the transformed cells were transferred to $5 \mathrm{ml}$ pre-warmed CGM and incubated at $37^{\circ} \mathrm{C}$ for $3 \mathrm{~h}$ prior to plating on RCM plates containing $40 \mu \mathrm{g} / \mathrm{ml} \mathrm{Em}$. Plates were incubated to develop the mutant colonies in $37^{\circ} \mathrm{C}$ anaerobic incubator for 3-5 days.

\section{Southern Hybridization}

Restriction enzyme SmaI was used to digest the chromosomal DNA of both wild type and mutant completely at $30^{\circ} \mathrm{C}$. After being separated on a $1 \%$ agarose gel with low voltage, all digested DNA fragments were transferred from the agarose gel to a Hybond- $\mathrm{N}^{+}$nylon membrane (Amersham, Piscataway, NJ) by upward Southern capillary transfer. Pre-hybridization of blotted nylon membrane was performed at $50^{\circ} \mathrm{C}$ for $1 \mathrm{~h}$. Two probes were used separately for the hybridization of $\mathrm{Em}^{\mathrm{r}}$ gene and pta gene. The $\mathrm{Em}^{\mathrm{r}}$ probe was prepared from HindIII-digested pPTA-Em followed with SacI digestion, resulting in a partial $\mathrm{Em}^{\mathrm{r}}$ gene fragment of $\sim 345 \mathrm{bp}$. The pta probe was the same as the cloned pta fragment from PCR. Both probes and the HindIIIdigested $\lambda$ DNA, which was used as DNA-size marker, were labeled with alkaline phosphatase (Amersham). The hybridization with the probes was carried out with gently shaking at $62^{\circ} \mathrm{C}$ overnight. Hyperfilm ${ }^{\text {TM }}$ ECL (Amersham) was then used for the detection.

\section{Characterization of Mutant}

The protein expression pattern and the enzyme activities of PTA, AK, PTB and BK in the ptadeleted mutant (PPTA-Em) were studied. Fermentations were performed to further characterize PPTA-Em in its butyrate production and sensitivity to butyrate inhibition.

Preparation of Cell Extract. Bacteria were grown in $50 \mathrm{ml} \mathrm{CGM}$ at $37^{\circ} \mathrm{C}$ to the exponential phase $\left(\mathrm{OD}_{600}=\sim 1.5\right)$. Cells were harvested, washed and suspended in $5 \mathrm{ml}$ of 25 $\mathrm{mM}$ Tris/HCl ( $\mathrm{pH}$ 7.4). The cell suspension was sonicated, and cell debris was removed by centrifugation. The protein content of extracts was determined following standard Bradford protocol (Bio-Rad).

SDS-PAGE and Two-Dimensional Protein Electrophoresis. Protein samples for SDSPAGE electrophoresis were prepared following standard protocol (Bio-Rad). Total protein samples (24 $\mu \mathrm{g}$ each) were loaded into wells and SDS-PAGE gel was run at $100 \mathrm{~V}$ for $3 \mathrm{~h}$ with 
PROTEAN II xi Cell (Bio-Rad). For two-dimensional protein electrophoresis (2DE) analysis, cell extract was concentrated by acetone and then dissolved in rehydration buffer ( $8 \mathrm{M}$ urea, $4 \%$ CHAPS, $10 \mathrm{mM}$ DTT, $0.2 \%(\mathrm{w} / \mathrm{v})$ Bio-Lytes 3/10) for sample preparation. The first dimension was performed on a $7 \mathrm{~cm}$ IPG strip with a nonlinear immobilized $\mathrm{pH}$ 3-10 gradient (Amersham). The IPG strip was rehydrated in rehydration buffer with $6 \mu \mathrm{g}$ protein sample at $50 \mathrm{~V}$ for $12 \mathrm{~h}$ using PROTEAN IEF Cell (Bio-Rad). After rehydration, the protein was focused on IPG strip by preset method, at $250 \mathrm{~V}$ for $15 \mathrm{~min}$ to remove excess salts, then ramped linearly from $250 \mathrm{~V}$ to $4000 \mathrm{~V}$ for $2 \mathrm{~h}$, and finally maintained at $4000 \mathrm{~V}$ for $5 \mathrm{~h}$ for focusing purpose. After isoelectric focusing (IEF), the strip was equilibrated in equilibrated buffer I (6 M urea, $2 \%$ SDS, $0.375 \mathrm{M}$ Tris- $\mathrm{HCl}, \mathrm{pH} 8.8,20 \%$ glycerol and $130 \mathrm{mM}$ DTT) for 10-15 min and in equilibrate buffer II (6 $\mathrm{M}$ urea, 2\% SDS, $0.375 \mathrm{M}$ Tris-HCl, $\mathrm{pH} 8.8,20 \%$ glycerol and $135 \mathrm{mM}$ iodoacetamide) for 1015 min. The equilibrated strip was applied to a polyacrylamide/PDA SDS gel to run the second dimension electrophoresis at $100 \mathrm{~V}$ for 90-120 min with Mini-PROTEAN 3 Cell (Bio-Rad). The protein spots were developed using silver staining kit (Amersham). The two-dimensional protein electrophoresis gels were analyzed using Phoretix 2D Advanced ${ }^{\mathrm{TM}}$ software (Nonlinear Dynamics Ltd, Newcastle upon Tyne, UK).

Enzyme Assays. The activities of acetate kinase (AK) and butyrate kinase (BK) were measured by monitoring the formation of acyl phosphate from acetate and butyrate, respectively, at $540 \mathrm{~nm}$ (Rose, 1955). Enzyme activity was calculated on the basis of a molar extinction coefficient of $0.169 \mathrm{mM}^{-1} \mathrm{~cm}^{-1}$ (Cary et al., 1988). One unit of AK and BK activity was defined as the amount of enzyme that produces $1 \mu$ mol of hydroxamic acid per minute. Phosphotransacetylase (PTA) and phosphotransbutyrylase (PTB) were assayed by detecting the liberation of CoA from acetyl-CoA and butyryl-CoA at $405 \mathrm{~nm}$, respectively (Andersch et al., 1983). An extinction coefficient of $13.6 \mathrm{mM}^{-1} \mathrm{~cm}^{-1}$ was used for activity calculation. One activity unit of PTA and PTB was defined as the amount of enzyme converting $1 \mu \mathrm{mol}$ of acyl-CoA or butyryl-CoA per minute under the reaction conditions. Specific activity of all enzymes was defined as the unit of activity per $\mathrm{mg}$ of protein. For each enzyme, the data reported are from two separate assays with two duplicates in each assay.

Fermentation Kinetic Study. Batch and fed-batch fermentations of C. tyrobutyricum were performed in a $5 \mathrm{~L}$ stirred-tank fermentor (Marubishi MD-300) containing $2 \mathrm{~L}$ of clostridial growth medium (CGM) supplemented with glucose $(30 \mathrm{~g} / \mathrm{L})$ and $40 \mu \mathrm{g} / \mathrm{ml}$ erythromycin (Em) as required. Anaerobiosis was reached by initially sparging the medium with nitrogen. The medium $\mathrm{pH}$ was adjusted to $\sim 6.0$ with $6 \mathrm{~N} \mathrm{HCl}$ before inoculation with $\sim 100 \mathrm{ml}$ of cell suspension prepared in a serum bottle. Experiments were carried out at $37^{\circ} \mathrm{C}, 150 \mathrm{rpm}$, and $\mathrm{pH} 6.0$ controlled by $\mathrm{NH}_{4} \mathrm{OH}$. The fed-batch mode was operated by pulse feeding concentrated substrate solution when the sugar level in the fermentation broth was close to zero. The feeding was continued until the fermentation ceased to produce butyrate due to product inhibition. $\mathrm{Gas}_{(\mathrm{H}}\left(\mathrm{H}_{2}\right.$ and $\mathrm{CO}_{2}$ ) production in the fermentation was monitored using an on-line respirometer system equipped with both $\mathrm{H}_{2}$ and $\mathrm{CO}_{2}$ sensors (Micro-oxymax, Columbus Instrument). Samples were taken at regular intervals from the fermentation broth for the analyses of cell, substrate and products. A high performance liquid chromatograph (HPLC) was used to analyze the organic compounds, including glucose, butyrate, and acetate in the liquid samples (Wu and Yang, 2003).

Inhibition Effect of Butyrate on Cell Growth. Cultures of C. tyrobutyricum were grown in serum tubes containing $10 \mathrm{ml}$ of media with various concentrations of butyrate $(0-15 \mathrm{~g} / \mathrm{L})$ to evaluate the inhibition effect of butyrate on cell growth, which was followed by measuring the 
optical density at $600 \mathrm{~nm}\left(\mathrm{OD}_{600}\right)$ with a spectrophotometer (Sequoia-Turner, Model 340). Specific growth rates were estimated from the $\mathrm{OD}_{600}$ data.

\section{RESULTS}

\section{PCR Amplification and Sequence Analysis}

One DNA fragment with expected size of $\sim 730$ base nucleotides was generated with degenerate primers by PCR amplification. This DNA fragment was cloned into pCR 2.1 vector. The resulting plasmid, designated as pCR-PTA, was then transformed into E. coli. Positive clones were identified, and nucleotide sequencing of the pta fragment showed 732 nucleotides, encoding for 244 amino acids, which can be found in GenBank (GBAN AY572855). The partial amino acid sequence of PTA of $C$. tyrobutyricum was then compared with the known sequences of complete PTA from several other microorganisms. As shown in the homology alignment (Fig. B.2), there are high degrees of identities and similarities between $C$. tyrobutyricum and $C$. acetobutylicum (70\%), Methanosarcina thermophila (56\%), E. coli (51\%), B. subtilis (47\%), Mycoplasma genitalium (47\%), and P. denitrificans (47\%), confirming that the PCR product was from the pta gene in C. tyrobutyricum.

\section{Transformation}

The non-replicative plasmid pPTA-Em $(4.75 \mathrm{~kb})$ was constructed and used to transform $C$. tyrobutyricum by electroporation. Before electroporation, the protoplast of $C$. tyrobutyricum was prepared to examine the presence of restriction system on this plasmid. The inability to detect any digestion of the plasmid suggested that no restriction enzymes were present in $C$. tyrobutyricum, similar to the results previously obtained with Clostridium pasteurianum ATCC 6013 (Richards et al., 1988). After electroporation, a selective pressure of Em was used to detect mutant cells containing the non-replicative plasmids. A total of $\sim 10$ Em-resistant colonies were obtained after electroporation with a transformation efficiency of 1 colony per $\mu \mathrm{g}$ DNA, which was similar to those obtained for the integrational plasmids in C. acetobutylicum ATCC 824 (Green and Bennett, 1998; Green et al., 1996). As a negative control, non-replicative plasmid with $\mathrm{Em}^{\mathrm{r}}$ cassette but without the pta fragment was also used to transform the C. tyrobutyricum cells. As expected, no transformed mutant was obtained since the plasmid cannot be replicated in the cells without first integrating into the chromosome via homologous recombination. Therefore, the pPTA-Em must have been integrated into the chromosome by homologous recombination in the transformed cells. Since the homologous region in pPTA-Em is the internal DNA sequence of pta, the transformed cells were mutagenic and the original pta gene on the chromosome have been disrupted.

\section{Southern Hybridization}

DNA hybridization was performed to localize the integration site of the non-replicative plasmid on the parental chromosome. Both SmaI digested PPTA-Em and wild type chromosomal DNA was identified with two probes (partial $\mathrm{Em}^{\mathrm{r}}$ and pta gene) following the method described by Green et al. (Green et al., 1996). It is noted that the non-replicative plasmid pPTA-Em had unique SmaI restriction site in the backbone and there was no SmaI site in the pta insert. As shown in Fig. B.3, the $\mathrm{Em}^{\mathrm{r}}$ probe only hybridized to one $S m a \mathrm{I}$ fragment $(6.3 \mathrm{~kb})$ from mutant PPTA-Em but none from the wild type strain, indicating that the integrational plasmid was inserted into the chromosomal DNA of the mutant since the $6.3-\mathrm{kb}$ fragment contained the 
antibiotics gene from the plasmid pPTA-Em. Meanwhile, two SmaI fragments (approximate 4.5 $\mathrm{kb}$ and $6.3 \mathrm{~kb}$ ) from the mutant strain and a $6-\mathrm{kb} S m a I$ fragment from the wild type strain were detected by the pta probe (Fig. B.3). The total size $(10.8 \mathrm{~kb})$ of the pta probe hybridized fragments from the mutant $(4.5 \mathrm{~kb}+6.3 \mathrm{~kb})$ was equal to the size of pta hybridized fragment from the wild type $(6.0 \mathrm{~kb})$ plus the size of the plasmid pPTA-Em $(4.8 \mathrm{~kb})$, indicating that pPTAEm had been inserted into the parental pta gene on the chromosome in the mutant through homologous recombination (Campbell, 1962), as illustrated in Fig. B.3. Since pPTA-Em was internal to the pta gene, the original pta gene on the chromosome was disrupted and has lost its function, producing the pta-deleted mutant PPTA-Em.

\section{Protein Expression}

The effects of pta gene disruption on protein expression in the mutant cells were evaluated with SDS-PAGE and 2DE analyses. The SDS-PAGE gel clearly showed that the highly expressed protein in the wild type with molecular weight of $\sim 32 \mathrm{kDa}$ diminished in PPTA-Em mutant (Fig. B.4). Fig. B.5 shows the two-dimensional protein analysis of wild type and mutant PPTA-Em grown at $37^{\circ} \mathrm{C}, \mathrm{pH} 6.0$, and with glucose as the carbon source. The $2 \mathrm{DE}$ gels were analyzed with the Phoretix 2D Advanced $^{\mathrm{TM}}$ software, which also normalized the different intensities of the protein spots on these gels for easy comparison. As can be seen in Fig. B.5, the number of proteins and their expression levels were altered in the mutant PPTA-EM. At least two proteins with molecular weight of $\sim 32 \mathrm{kDa}$ (spot \#57, PI $\approx 6.2$ and spot \#60, PI $\approx 6.8$ ) in the wild type were missing and one protein (\#58) highly expressed in wild type was dramatically down regulated in the mutant. This result is consistent with the finding from the SDS-PAGE analysis. The missing proteins in the mutant were probably AK and PTA. Disrupting the pta gene might have resulted in the deletion of both AK and PTA from the mutant PPTA-Em since both pta and ack genes are most likely to be in the same operon with pta gene being upstream of the ack gene, as found in several microorganisms including C. acetobutylicum (Boynton et al., 1996).

\section{Acid-Forming Enzyme Activities}

Exponential-phase cultures of C. tyrobutyricum wild type and PPTA-Em mutant were harvested, and the cell extracts were assayed for acetate and butyrate-producing enzymes PTA, AK, PTB, and BK. As shown in Fig. B.6, although the activities of PTA and AK were reduced dramatically, the mutant PPTA-Em still had some activities of PTA (40\%) and AK (20\%). The smaller decrease in the PTA activity is probably because the cloned pta fragment is near the stop codon of the gene and after recombination, most part of the pta gene is intact on the chromosome. However, the lowered PTA and AK activities in the mutant were more likely from other enzymes that also can produce acetate from the same substrates (Rogers and Gottschalk, 1993). The mutant also had a higher BK activity $(\sim 135 \%)$ and similar PTB activity, as compared to the wild type strain. The greatly reduced AK enzyme activity in PPTA-Em also indicates that the ack gene lies downstream from pta gene in the same operon.

After growing the mutant in the medium without Em for $\sim 10$ generations ( $48 \mathrm{~h}$ ), no differences in the key enzyme activities were detected as compared to the mutant in the antibiotics-containing medium, indicating no revertants (data not shown). Also, there was no obvious change in cell growth and acid production kinetics in repeated batch fermentations even in the absence of the antibiotics (data not shown). It thus can be concluded that the mutant with gene mutation resulted from the homologous recombination on the chromosome is stable and can be maintained without using the antibiotics in long-term fermentation. 


\section{Fermentation Kinetics}

Fig. B.7 shows the kinetics of fed-batch fermentations with the mutant and the wild type strains. The mutant grew exponentially in the first fed-batch and then entered the stationary phase. It continued to produce butyrate until the butyrate concentration reached $32.5 \mathrm{~g} / \mathrm{L}$, which was much higher than that obtained in the wild-type fermentation $(20.2 \mathrm{~g} / \mathrm{L})$. However, a significant amount of acetate was still produced by the mutant and reached $\sim 4.28 \mathrm{~g} / \mathrm{L}$. It was found that the mutant had a lower specific growth rate than that of the wild type, although its cell yield appeared to be higher. Table 2 compares the fermentation results from the mutant and the wild type. It is clear that pta deletion resulted in lower acetate yield, higher butyrate yield, final concentration, and productivity, and consequently, higher selectivity of butyrate over acetate. Besides the greatly increased final butyrate concentration produced by the mutant, the butyrate yield was also increased, from $0.33 \mathrm{~g} / \mathrm{g}$ by the wild type to $0.38 \mathrm{~g} / \mathrm{g}$ by the mutant, and the acetate yield decreased from $0.067 \mathrm{~g} / \mathrm{g}$ by the wild type to $0.058 \mathrm{~g} / \mathrm{g}$ by the mutant. There was significant improvement in butyrate productivity by the mutant $(0.63 \mathrm{~g} / \mathrm{L} \cdot \mathrm{h})$, which was about 1.9 fold higher than that of the wild type $(0.33 \mathrm{~g} / \mathrm{L} \cdot \mathrm{h})$. However, inactivation of the pta gene did not completely eliminate acetate formation, indicating that additional acetate-forming enzymes were probably present in C. tyrobutyricum. Also, the higher butyrate concentration produced by the mutant in the fed-batch fermentation suggested a phenotypic change in its butyrate tolerance, which was unexpected in the original experimental design. It is noted that the carbon balance in the fermentation was close to $100 \%$ for both the wild type $(95.3 \%)$ and the mutant $(100 \%)$ (see Table 2), indicating a complete recovery of carbon in the fermentation products and cells from the substrate, glucose.

\section{Butyrate Tolerance}

To determine the phenotypic change about butyrate tolerance in mutant strain, cells were grown as free-cell suspension cultures at different initial butyrate concentrations $(0 \sim 15 \mathrm{~g} / \mathrm{L})$. The specific growth rates determined from the growth data are shown as the relative growth rate with the rate at zero initial butyrate concentration being 100\%. As shown in Fig. B.8, the pta-deleted mutant had a much higher tolerance to butyric acid than the wild type. At $15 \mathrm{~g} / \mathrm{L}$ of butyric acid, the mutant retained $\sim 30 \%$ of its maximum growth rate as compared to less than $10 \%$ in the wild type. The growth inhibition by butyric acid followed the non-competitive inhibition kinetics with the inhibition rate constants $K_{P}$ equal to $1.59 \mathrm{~g} / \mathrm{L}$ and $5.56 \mathrm{~g} / \mathrm{L}$ for the wild type and mutant, respectively. It is clear that butyric acid strongly inhibited cell growth of the wild type but not as strongly to the mutant.

\section{DISCUSSION}

\section{Cloning of $C$. tyrobutyricum}

The partial pta gene in C. tyrobutyricum ATCC 25755 was successfully cloned and sequenced using degenerate primers. One integrational plasmid (pPTA-Em) was constructed with the cloned pta fragment, which was then introduced into the chromosomal DNA of the parental bacterium via electroporation and homologous recombination, and the pta gene on the chromosome was successfully inactivated. This is the first time a genetically engineered mutant of C. tyrobutyricum has been successfully created for butyric acid fermentation. Although similar cloning work has been done with other Clostridia species, the cloning procedures for $C$. tyrobutyricum used in this work were developed after careful optimization. For PCR 
amplification, the optimal $\mathrm{Mg}^{2+}$ concentration in the buffer was found to be $2.5 \mathrm{mM}$ and the optimal primer annealing temperature was $48^{\circ} \mathrm{C}$. Decreasing the annealing temperature reduced the reaction specificity and enhanced the incorrect anneal of the degenerate primers.

The electroporation method to transform plasmids into C. tyrobutyricum was developed after optimizing the conditions used in preparing the competent cells, the selection of an appropriate electroporation buffer, and the electroporation gene pulser parameters. The choice of electroporation buffer was important to transform $C$. tyrobutyricum. Several electroporation buffers referred in the literature (Phillips-Jones, 1995), including 15\% glycerol, 10\% (w/v) PEG 8000, SP buffer (270 mM sucrose, $\left.5 \mathrm{mM} \mathrm{NaH} \mathrm{PO}_{4}, \mathrm{pH} 7.4\right)$ and the SMP buffer (270 mM sucrose, $1 \mathrm{mM} \mathrm{MgCl}_{2}, 7 \mathrm{mM}$ sodium phosphate, $\mathrm{pH}$ 7.4) were evaluated, and the last one was found to work the best for $C$. tyrobutyricum. The highest transformation efficiency was obtained by using mid-log phase cells $\left(\mathrm{OD}_{600}=0.8-1.0\right)$ instead of late-log phase $\left(\mathrm{OD}_{600}=\sim 2.0\right)$. This result is similar to that observed with $C$. botulinum (Zhou and Johnson, 1993) and $C$. acetobutylicum DSM 792 (Nakotte, 1998), but different from the result obtained in $C$. perfringens, in which the optimal transformation efficiency was found with cells harvested from the late-log phase (Allen and Blaschek, 1990) or the stationary phase (Phillips-Jones, 1990). The gene pulser parameters, including the voltage $2.5 \mathrm{kV}$ with the field strength of $6.25 \mathrm{kV} / \mathrm{cm}$ and the electrical resistance $600 \Omega$ with a capacitance $25 \mu \mathrm{F}$, were applied in electroporation. It is found that decreasing the discharge to $2.0 \mathrm{kV}$ and increasing the resistance to $\infty$ did not improve the transformation efficiency with $C$. tyrobutyricum. The pulse duration under the optimized conditions was $6.3-7.5 \mathrm{~ms}$. Also, the transformation efficiency of $C$. tyrobutyricum by electroporation was enhanced with the addition of DL-threonine in the medium, which helped to weaken the cell wall of gram-positive microorganism by incorporation of the D-isomer (van der Lelie et al., 1988). It is noted that the optimized transformation conditions are somewhat different from the ones previously reported and commonly used for other clostridia. No transformed colonies of $C$. tyrobutyricum could be obtained under the previously reported electroporation conditions. The improved electroporation method provides an efficient way to introduce foreign genes into $C$. tyrobutyricum with a transformation efficiency of 1 colony per $\mu \mathrm{g}$ DNA for non-replicative plasmids, which is similar to the result for C. acetobutylicum ATCC 824 (Green et al., 1996). It opens the way for future molecular genetic studies in $C$. tyrobutyricum.

\section{Protein Expression}

In this work, both SDS-PAGE gel and two-dimensional protein electrophoresis (2DE) maps showed that at least two proteins (spot \#57 and \#60) found in the wild type were not expressed in the pta-deleted mutant. These missing proteins are most likely to include PTA and AK, but cannot be identified in this work due to lack of proteomic information for C. tyrobutyricum. Phosphotransacetylase (PTA) and acetate kinase (AK) from several microorganisms have been purified and characterized (Boyton, et al., 1996). PTA is a monomer with a molecular weight of approximate $36.2 \mathrm{kDa}$ in $C$. acetobutylicum, $88 \mathrm{kDa}$ in $C$. thermoaceticum, and $27 \mathrm{kDa}$ in $S$. pyogenes. AK is a dimer of two identical subunits with various molecular masses in different species, $44.3 \mathrm{kDa}$ in C. acetobutylicum and $60 \mathrm{kDa}$ in C. thermoaceticum. Only the PI values of PTA and AK for some E. coli strains are available in the literature (Kirkpatrick et al., 2001; Peng and Shimizu, 2003). The large variations in PI and molecular weight for AK and PTA from different microorganisms make it difficult to identify AK and PTA on the 2DE gels. Further 
studies and analysis of the proteins isolated from the 2DE gels was necessary to confirm their identities.

\section{Effects of Inactivating pta Gene}

Gene inactivation has been proved to be a feasible genetic engineering technique for studying molecular genetics in $C$. acetobutylicum (Harris, et al., 2000), but has not been applied to $C$. tyrobutyricum. In this work, the pta gene in the acetate-forming pathway in C. tyrobutyricum was inactivated by integration of a non-replicative plasmid on the chromosome. The enzyme activity assays showed that both PTA and AK activities were reduced greatly in the pta-deleted mutant, suggesting that deletion of the pta gene also resulted in the inactivation of ack gene. This finding is consistent with the study of the pta-deleted mutant of $C$. acetobutylicum (Green et al., 1996), and suggests that the acetic acid-forming genes, pta and ack, exist in the same operon with pta preceding ack (Boynton, et al., 1996). However, PTA and AK activities were still detected in the mutant, which probably came from other enzymes working with the same substrates as PTA and AK. The specific activities of PTB and BK enzymes involving in the formation of butyrate were either unaffected or increased. It is possible that the deletion of the acetate formation pathway had pushed more carbon and energy sources to flow through the butyrate formation pathway, which required a higher BK enzyme activity for the increased flux. Fermentation study showed that the pta-deleted mutant produced more butyrate from glucose but was still capable of producing acetate. The butyrate yield increased $\sim 15 \%$ while acetate yield decreased only $\sim 14 \%$, even though the specific activities of PTA and AK in the mutant had been reduced by more than $50 \%$ as compared to the wild type. The chance for a revertant to appear in the fermentation was low even when Em was not included in the fermentation medium. Therefore, there must be other enzymes besides PTA and AK in C. tyrobutyricum that also can produce acetate from acetyl-CoA and perhaps other substrates as well. For example, CoA transferase can catalyze the formation of acetate from acetyl-CoA. This enzyme has been found in some clostridia bacteria (Rogers and Gottschalk, 1993), and could also be present in $C$. tyrobutyricum. It also has been reported that PTB and BK exhibited broad substrate specificities with C2- to C6-chained acyl-CoA and carboxylic acid compounds in C. acetobutylicum (Wiesenborn et al., 1989; Hartmanis, 1987). The butyrate-producing enzymes PTB and BK in $C$. tyrobutyricum mutant might have been responsible for the observed acetate production in the fermentation. It is also possible that there is additional acetate formation pathway catalyzed by other enzymes in C. tyrobutyricum, as was reported for some species (Lindmark, 1976). Possible presence of PTA and AK isozymes also could not be ruled out. Two acetate kinase isozymes from spirochete MA-2 cell extracts (Harwood and Canale-Parola, 1982) and a butyrate kinase isoenzyme (BKII) in C. acetobutylicum ATCC 824 (Huang, et. al, 2000) have been reported.

Inactivation of pta also had a significant effect on cell growth. Compared to the wildtype, the mutant PPTA-Em had a reduced specific growth rate, but had a higher cell yield from glucose (Table 2). This observation is similar to that found in pta or buk inactivated $C$. acetobutylicum (Green et al., 1996). Since both acid-formation pathways are responsible for generating energy (ATP) for cells, a reduced acetate production may impose a metabolic burden on cells. A feasible cellular response to this metabolic burden is the elevation of the flux through the alternate ATP-generation pathway, namely butyrate formation, to avoid any significant loss in overall cell growth. This metabolic change might have resulted in the observed increase in cellular BK enzyme activity. Since the acetate formation pathway can produce more ATP per 
glucose metabolized than the butyrate formation pathway, the elimination of acetate metabolic pathway resulted in reduced energy production efficiency, which in turn could direct more substrates towards the butyrate formation pathway to offset loss in the ATP generation and overall cell growth. This also could explain why biomass production was increased in the mutant even though the specific growth rate was lowered.

Compared to the wild type, the butyrate tolerance of pta-deleted mutant had significantly enhanced butyrate tolerance (Fig. 8), which is unexpected but can explain the observed higher butyrate productivity and final butyrate concentration in the fermentation with the mutant. It had been noted that PTA in C. tyrobutyricum was more strongly inhibited by butyric acid than PTB (Zhu and Yang, 2003). It is thus possible that by disrupting the butyrate-sensitive PTA and acetate-forming pathway, the mutant became less sensitive to butyrate inhibition since they used mainly the butyrate-forming pathway to generate ATP needed for biosynthesis and maintaining a functional $\mathrm{pH}$ gradient across the cell membrane. It should be noted, however, that cultures adapted and grown in a fibrous-bed bioreactor (FBB) were much more tolerant to butyrate inhibition and produced more butyric acid from glucose than those obtained in free-cell fermentations (Zhu and Yang, 2003). With the FBB, butyric acid can be produced at a concentration of higher than $50 \mathrm{~g} / \mathrm{L}$ with a high butyrate yield of more than $0.5 \mathrm{~g} / \mathrm{g}$ glucose.

\section{CONCLUSION}

This is the first genetic engineering study of $C$. tyrobutyricum for enhanced butyric acid fermentation. In this work, the cloning procedures for C. tyrobutyricum were optimized and gene inactivation experiments were carried out to develop mutant strains of $C$. tyrobutyricum for butyrate production from glucose with improved productivity, yield, final product concentration, and butyrate tolerance. The manipulation of acid-forming pathways by gene inactivation proved to be feasible for obtaining metabolically advantageous mutants for butyrate production from glucose. However, gene manipulations in the metabolic pathway can lead to unexpected changes in protein expression pattern and other phenotypes that require further studies.

\section{REFERENCES}

Allen SP, Blaschek HP. 1990. Factors involved in the electroporation-induced transformation of Clostridium perfringens. FEMS Microbiol. Lett. 70:217-220.

Andersch W, Bahl H, Gottschalk G. 1983. Levels of enzymes involved in acetate, butyrate, acetone and butanol formation by Clostridium acetobutylicum. Eur J Appl Microbiol Biotechnol 17:327-332.

Boynton ZL, Bennett GN, Rudolph FB. 1996. Cloning, sequencing, and expression of genes encoding phosphotransacetylase and acetate kinase from Clostridium acetobutylicum ATCC 824. Appl Environ Microbiol 62:2758-2766.

Campbell AM. 1962. Episomes. Adv Genet 11:101-146.

Cary JW, Peterson DJ, Papoutsakis ET, Bennett GN. 1988. Cloning and expression of Clostridium acetobutylicum phosphotransbutyrylase and butyrate kinase genes in Escherichia coli. J Bacteriol 170:4613-4618.

Green EM, Bennett GN. 1998. Genetic manipulation of acid and solvent formation in Clostridium acetobutylicum ATCC 824. Biotechnol Bioeng 58:215-221.

Green EM, Boynton ZL, Harris LM, Rudolph FB, Papoutsakis ET, Bennett GN. 1996. Genetic manipulation of acid formation pathways by gene inactivation in Clostridium acetobutylicum ATCC 824. Microbiol 142:2079-2086. 
Guérout-Fleury AM, Shazand K, Frandsen N, Stragier P. 1995. Antibiotic-resistance cassettes for Bacillus subtilis. Gene 167:335-336.

Harris LM, Desai RP, Welker NE, Papoutsakis ET. 2000. Characterization of recombinant strains of the Clostridium acetobutylicum butyrate kinase inactivation mutant: need for new phenomenological models for solventogenesis and butanol inhibition? Biotechnol Bioeng 67:111 .

Hartmanis MGN. 1987. Butyrate kinase from Clostridium acetobutylicum. J Biol Chem 262:617621.

Harwood CS, Caale-Parola E. 1982. Properties of acetate kinase isozymes and a branched-chain fatty kinase from a spirochete. J Bacteriol 152:246-254.

Huang KX, Huang S, Rudolph FB, Bennett GN. 2000. Identification and characterization of a second butyrate kinase from Clostridium acetobutylicum ATCC 824. J Mol Microbiol Biotechnol 2:33-38.

Huang Y L, Mann K, Novak J M, Yang S T. 1998. Acetic acid production from fructose by Clostridium formicoaceticum immobilized in a fibrous-bed bioreactor. Biotechnol Prog 14:800806.

Kakuda H, Hosono K, Shiroshi K, Ichihara S. 1994. Identification and characterization of the ackA (acetate kinase A) - pta (phosphotransacetylase) operon and complementation analysis of acetate utilization by an ackA-pta deletion mutant of Escherichia coli. J Biochem 116:916-922.

Kirkpatrick C, Maurer LM, Oyelakin NE, Yoncheva YN, Mauer R, Slonczewski J L. 2001. Acetate and formate stress: opposite responses in the proteome of Escherichia coli. J Bacterial 183:6466-6477.

Latimer MT, Fery JG. 1993. Cloning, sequence analysis, and hyperexpression of the genes encoding phosphotransacetylase and acetate kinase from Methanosarcina thermophila. J Bacterial 175:6822-6829.

Lindmark DG. 1976. Acetate production by Tritrichomonas foetus. Biochem Parasites HostParasite Relat Proc Int Sym 10:15-21.

Matsuyama AH, Yamamoto H, Nakano E. 1989. Cloning, expression, and nucleotide sequences of the Escherichia coli K-12 ackA gene. J bacterial 171:77-580.

Michel-Savin D, Marchal R, Vandecasteele J P. 1990. Control of the selectivity of butyric acid production and improvement of fermentation performance with Clostridium tyrobutyricum. Appl Microbiol Biotechnol 32:387-392.

Michel-Savin D, Marchal R, Vandecasteele J P. 1990. Butyrate production in continuous culture of Clostridium tyrobutyricum: effect of end-product inhibition. Appl Microbiol Biotechnol 33:127-131.

Nakotte S, Schaffer S, Böhringer M, Dürrre P. 1998. Electroporation of, plasmid isolation from and plasmid conservation in Clostridium acetobutylicum DSM 792. Appl Microbiol Biotechnol 50:564-567.

Papoutsakis ET, Meyer CL. 1985. Equations and calculations of product yields and preferred pathways for butanediol and mixed-acid fermentations. Biotechnol Bioeng 27:50-66.

Peng L, Shimizu K. 2003. Global metabolic regulation analysis for Escherichia coli K12 based on protein expression by 2-dimensional electrophoresis and enzyme activity measurement. Appl Microbiol Biotechnol 61:163-178.

Phillips-Jones M K. 1990. Plasmid transformation of Clostridium perfringens by electroporation methods. FEMS Microbiol Lett 66:221-226. 
Phillips-Jones MK. 1995. Introduction of recombinant DNA into Clostridium spp. In: Nickoloff JA, editor. Methods in Molecular Biology, vol. 47. Electroporation protocols for microorganisms. New York: Hunana Press Inc. p 227-235.

Richards DF, Linnett PE, Oultram JD, Young M. 1988. Restriction endonucleases in Clostridium pasteurianum ATCC 6013 and C. thermohydrosulfuricum DSM 568. J Gen Microbiol 134:31513157.

Rogers P, Gottschalk G. 1993. Biochemistry and regulation of acid and solvent production in Clostridia. In: Woods DR, editor. The clostridia and biotechnology. Massachusetts: ButterworthHeinemann. p 25-50.

Rose IA. 1955. Acetate kinase of bacteria (acetokinase). Methods Enzymol 1:591-595. van Andel JG, Zouttberg GR, Crabbendam PM, Breure AM. 1985. Glucose fermentation by Clostridium butyricum grown under a self generated gas atmosphere in chemostat culture. Appl Microbiol Biotechnol 23:21-26.

van der Lelie D, van der Vossen JMBM, Venema G. 1988. Effect of plasmid incompatibility on DNA transfer to Streptococcus cremoris. Appl Environ Microbiol 54:865-871.

Vandak D, Zigova J, Sturdik E, Schlosser S. 1997. Evaluation of solvent and pH for extractive fermentation of butyric acid. Process Biochemistry 32:245-251.

Wiesenborn DP, Rudolph FB, Papoutsakis ET. 1989. Phosphotransbutyrylase from Clostridium acetobutylicum ATCC 824 and its role in acidogenesis. Appl Environ Microbiol 55:317-322.

$\mathrm{Wu}$ Z, Yang ST. 2003. Extractive fermentation for butyric acid production from glucose by Clostridium tyrobutyricum. Biotechnol Bioeng 82:93-102.

Zhou Y, Johnson EA. 1993. Genetic transformation of Clostridium Botulinum Hall A by electroporation. Biotechnol Lett 15:121-126.

Zhu Y, Wu Z, Yang ST. 2002. Butyric acid production from acid hydrolysate of corn fiber by Clostridium tyrobutyricum in a fibrous-bed bioreactor. Process Biochemistry, 38:657-666.

Zhu Y, Yang ST. 2003. Adaptation of Clostridium tyrobutyricum for enhanced tolerance to butyric acid in a fibrous-bed bioreactor. Biotechnol Prog, 19:365-372.

Zigova J, Sturdik E, Vandak D, Schlosser S. 1999. Butyric acid production by Clostridium butyricum with integrated extraction and pertraction. Process Biochemistry 34:835-843. 
Table 1. Bacterial strains and plasmids

\section{Strain/plasmid Characteristic Source/reference}

\section{Strain}

\section{C. tyrobutyricum}
ATCC 25755
$\mathrm{Em}^{\mathrm{s}}$
ATCC
PPTA-Em
$\operatorname{pta}^{-} \mathrm{Em}^{\mathrm{r}}$
Insertion of pPTA-Em into ATCC 25755; this study

E. coli
INV $\alpha$ F'
$\operatorname{rec} \mathrm{A} 1 \mathrm{Ap}^{\mathrm{r}}$
Invitrogen

\section{Plasmid}

$\begin{array}{lll}\text { pCR 2.1 } & \mathrm{Ap}^{\mathrm{r}} \mathrm{Km}^{\mathrm{r}} & \text { Invitrogen } \\ \text { pCR-PTA }^{\mathrm{a}} & \mathrm{Ap}^{\mathrm{r}} \mathrm{Km}^{\mathrm{r}} & \text { This study } \\ \text { pCR-PTA1 } & \mathrm{Ap}^{\mathrm{r}} & \text { This study } \\ \text { pDG 647 } & \mathrm{Ap}^{\mathrm{r}} \mathrm{Em}^{\mathrm{r}} & \text { Guérout-Fleury et al. (1995) } \\ \text { pPTA-Em }^{\mathrm{b}} & \mathrm{Ap}^{\mathrm{r}} \mathrm{Em}^{\mathrm{r}} & \text { This study }\end{array}$

${ }^{a}$ pCR-PTA was constructed by insertion of $0.73-\mathrm{kb}$ pta fragment into pCR 2.1 . bPTA-Em is the non-replicative integrational plasmid.

Note: Abbreviations: pta $^{-}$, phosphotransacetylase gene deleted; $\mathrm{Ap}^{\mathrm{r}}$, ampicillin resistant; $\mathrm{Km}^{\mathrm{r}}$, kanamycin resistant; $\mathrm{Em}^{\mathrm{r}}$, erythromycin resistant; recA1, homologous recombination abolished. 
Table 2. Comparison of fermentation results with the pta-deleted mutant PPTA-EM and the wild type strain of C. tyrobutyricum in fed-batch cultures controlled at $\mathrm{pH} 6.0,37^{\circ} \mathrm{C}$.

\begin{tabular}{|c|c|c|c|}
\hline \multicolumn{2}{|r|}{ Products } & Wild-type & PPTA-Em \\
\hline Cell & $\begin{array}{l}\mu\left(\mathrm{h}^{-1}\right) \\
\text { Yield } \quad(\mathrm{g} / \mathrm{g}) \\
\quad(\text { mole } \mathrm{C} / \mathrm{mole})^{*}\end{array}$ & $\begin{array}{l}0.19 \pm 0.02 \\
0.11 \pm 0.02 \\
0.77 \pm 0.14\end{array}$ & $\begin{array}{l}0.12 \pm 0.01 \\
0.16 \pm 0.02 \\
1.12 \pm 0.14\end{array}$ \\
\hline Butyrate & $\begin{array}{l}\text { Max Concentration }(\mathrm{g} / \mathrm{L}) \\
\text { Yield }(\mathrm{g} / \mathrm{g}) \\
\qquad(\text { mole } / \text { mole }) \\
\text { Productivity }(\mathrm{g} / \mathrm{L} \cdot \mathrm{h})\end{array}$ & $\begin{array}{c}20.2 \\
0.33 \pm 0.03 \\
0.68 \pm 0.06 \\
0.33\end{array}$ & $\begin{array}{c}32.5 \\
0.38 \pm 0.03 \\
0.78 \pm 0.06 \\
0.63\end{array}$ \\
\hline Acetate & $\begin{array}{l}\text { Max. Concentration }(\mathrm{g} / \mathrm{L}) \\
\text { Yield }(\mathrm{g} / \mathrm{g}) \\
\quad(\text { mole } / \text { mole })\end{array}$ & $\begin{array}{c}3.57 \\
0.067 \pm 0.003 \\
0.20 \pm 0.01\end{array}$ & $\begin{array}{c}4.28 \\
0.058 \pm 0.004 \\
0.17 \pm 0.01\end{array}$ \\
\hline Butyrate/ & cetate Ratio (g/g) & 4.95 & 6.55 \\
\hline Carbon di & xide (mole/mole) & $1.83 \pm 0.12$ & $1.51 \pm 0.09$ \\
\hline Carbon be & ance $(\%)$ & $95.3 \pm 4.22$ & $101 \pm 3.81$ \\
\hline
\end{tabular}

*Based on that the carbon content of cell biomass is $46.7 \%$ for Clostridia (Papoutsakis and Meyer, 1984) 


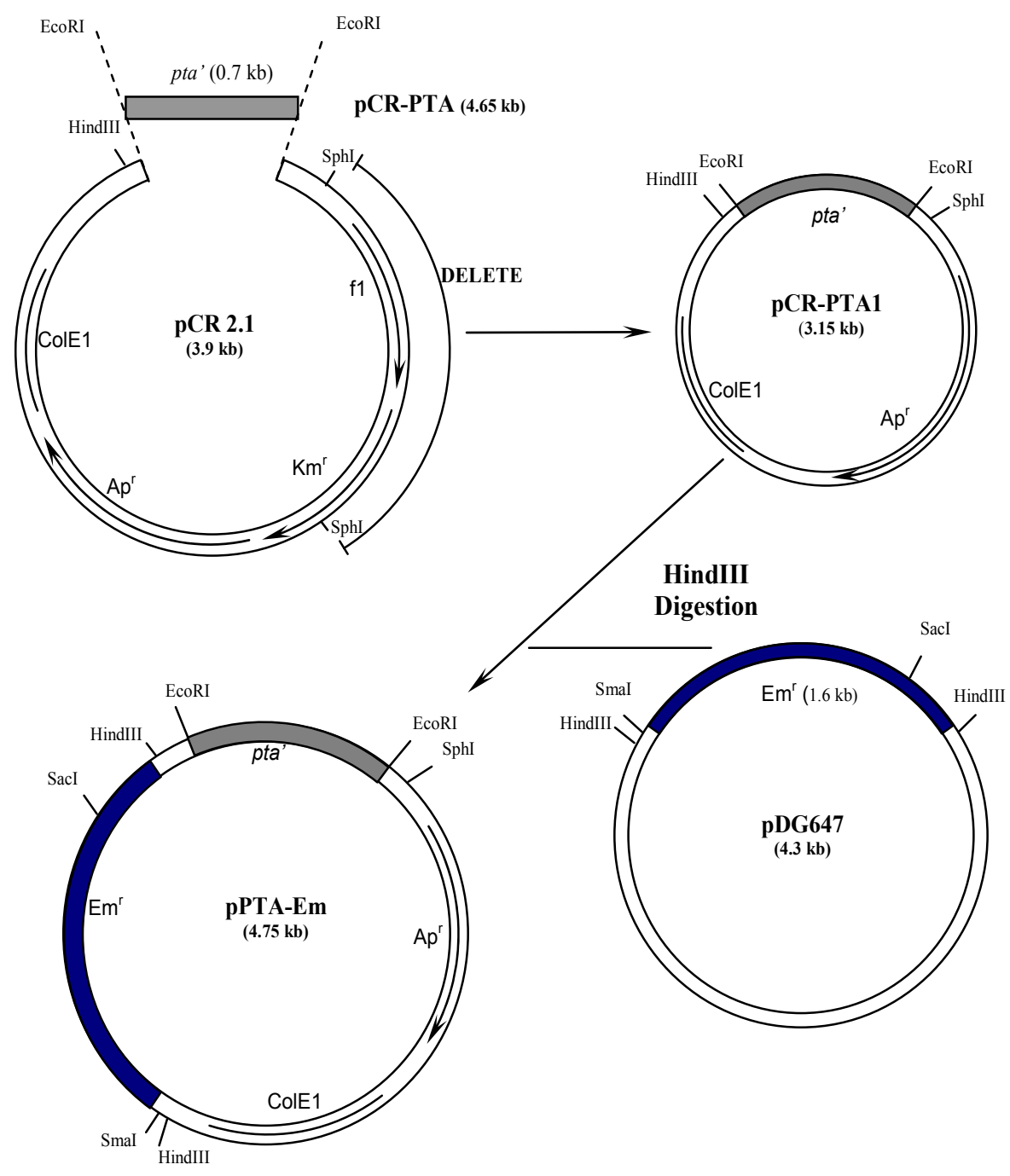

FIG. B.1. Construction of integrational plasmid pPTA-Em with one 0.7-kb pta fragment cloned from C. tyrobutyricum ATCC 25755. The directions of each gene are shown by arrows. Some important restriction sites used in this work are indicated. Abbreviations: pta, partial pta gene; f1, f1 filamentous phage origin of replication with helper phage; $\mathrm{Km}^{\mathrm{r}}$, kanamycin resistance gene; $\mathrm{Ap}^{\mathrm{r}}$, ampicillin resistance gene; $\mathrm{Em}^{\mathrm{r}}$, erythromycin resistance gene; ColE1, compatibility group origin of replication in E. coli. 

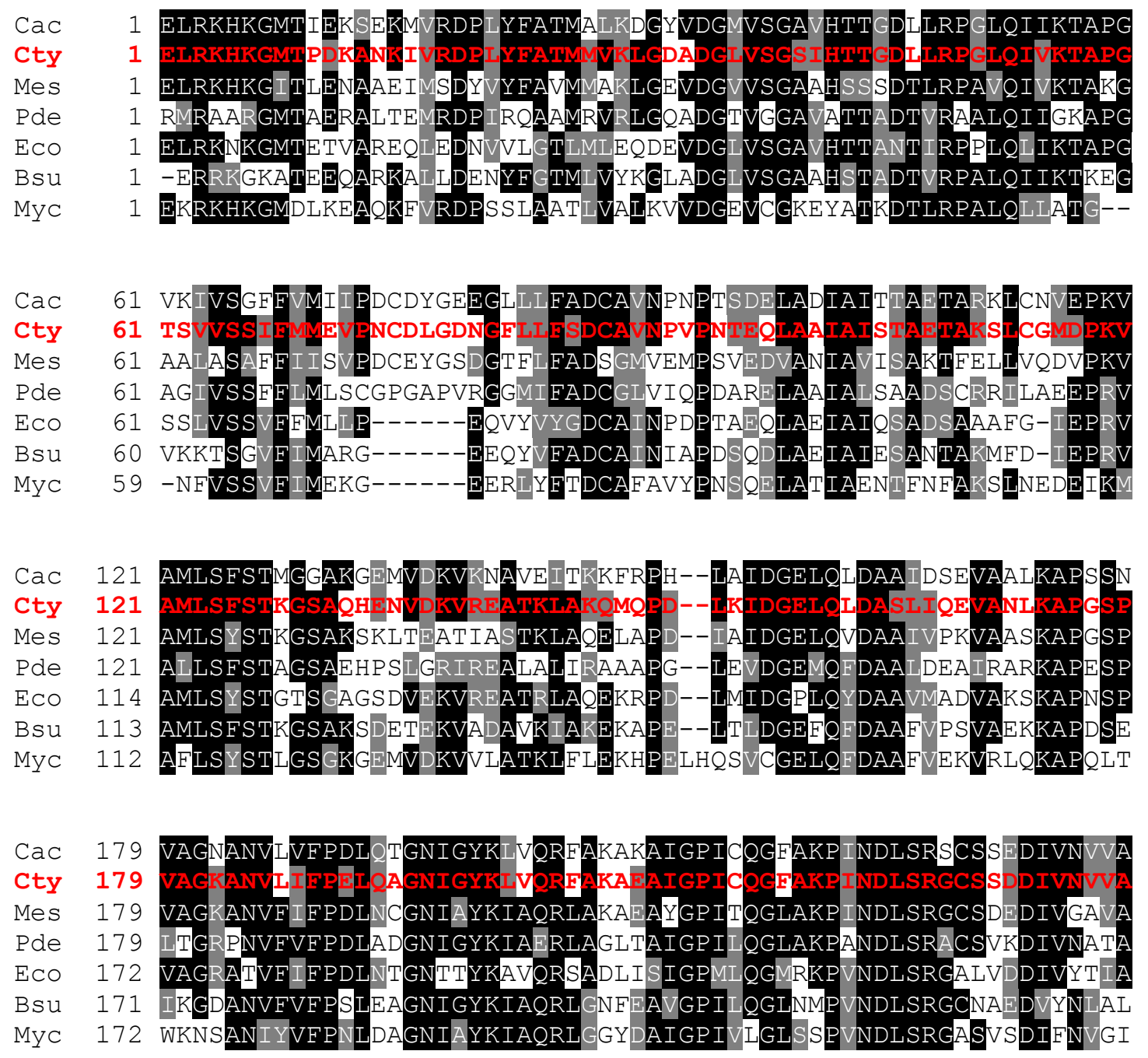

$\begin{array}{lll}\text { Cac } & 239 & \text { ITVVQA } \\ \text { Cty } & 239 & \text { ITAAQA } \\ \text { Mes } & 239 & \text { ITCVQA } \\ \text { Pde } & 239 & \text { ITAMQT } \\ \text { Eco } & 232 & \text { ITAIQS } \\ \text { Bsu } & 231 & \text { ITAAQA } \\ \text { Myc } & 232 & \text { ITAAQA }\end{array}$

FIG. B.2. Alignment of partial amino acid sequences of PTA from C. acetobutylicum (Cac; GBAN U38234), C. tyrobutyricum (Cty; GBAN AY572855), Methanosarcina thermophila (Mes; GBAN L23147), P. denitrificans (Pde; GBAN U08864), E. coli (Eco; GBAN D21123), B. subtilis (Bsu; GBAN; X73124), and Mycoplasma genitalium (Myc; GBAN L43967). 

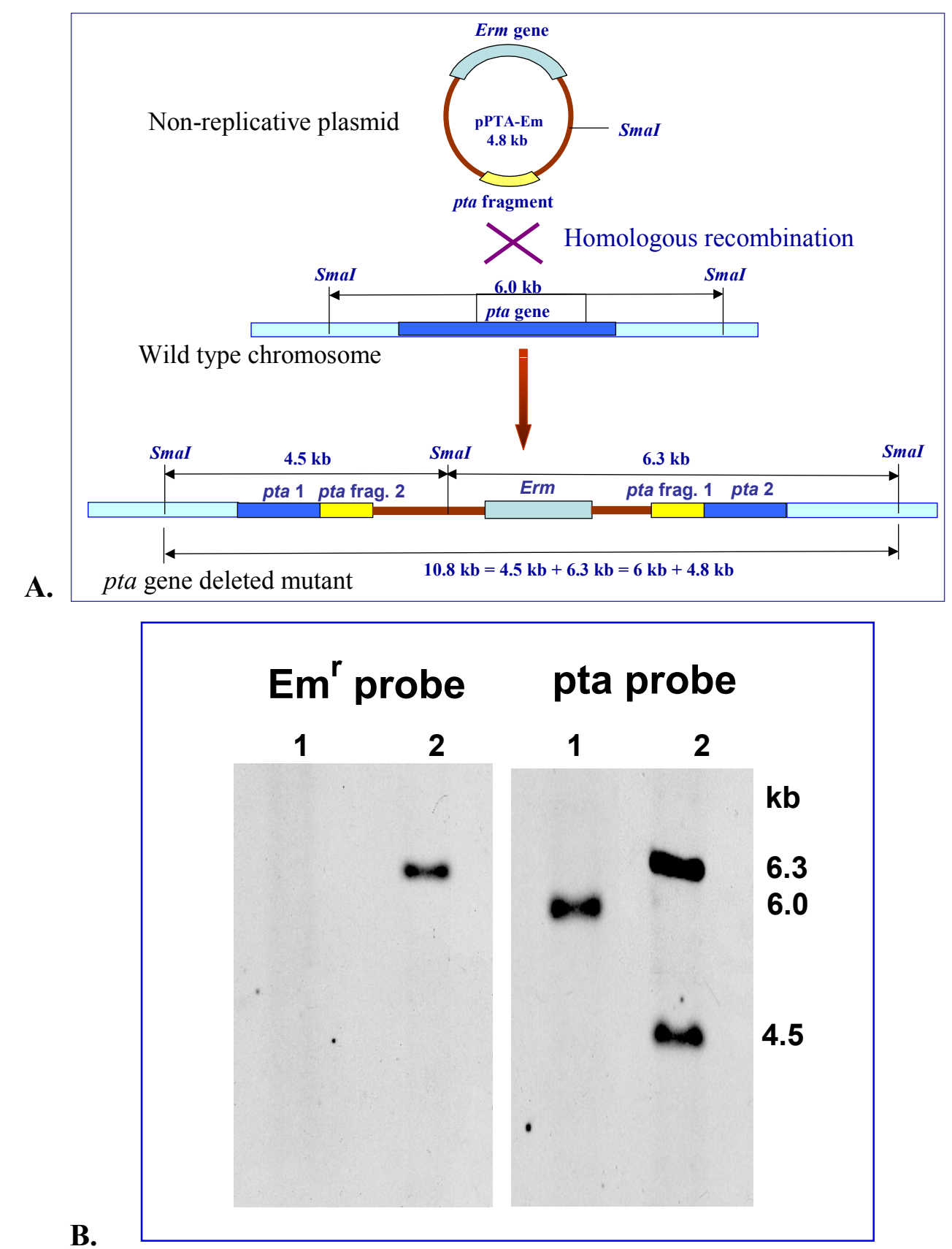

FIG. B.3. DNA hybridization. (A) Homologous recombination of plasmid $p P T A-E m$ containing partial pta gene with the chromosome, resulting in the disruption of pta gene. The restriction sites of SmaI and the DNA fragment sizes after cut are indicated. (B) Southern blots with Em ${ }^{\mathrm{r}}$ probe and pta probe. Wild type (Lane 1) showed no $\mathrm{Em}^{\mathrm{r}}$ and a $6.0 \mathrm{~kb}$ pta-containing DNA. The mutant PPTA-Em (Lane 2) showed both $\mathrm{Em}^{\mathrm{r}}$ and 2 pta-containing DNAs (6.3 kb and $\left.4.5 \mathrm{~kb}\right)$. The total size of these two DNAs is the same as the total size of the plasmid $(4.8 \mathrm{~kb})$ and the DNA containing the undisrupted pta $(6.0 \mathrm{~kb})$. 


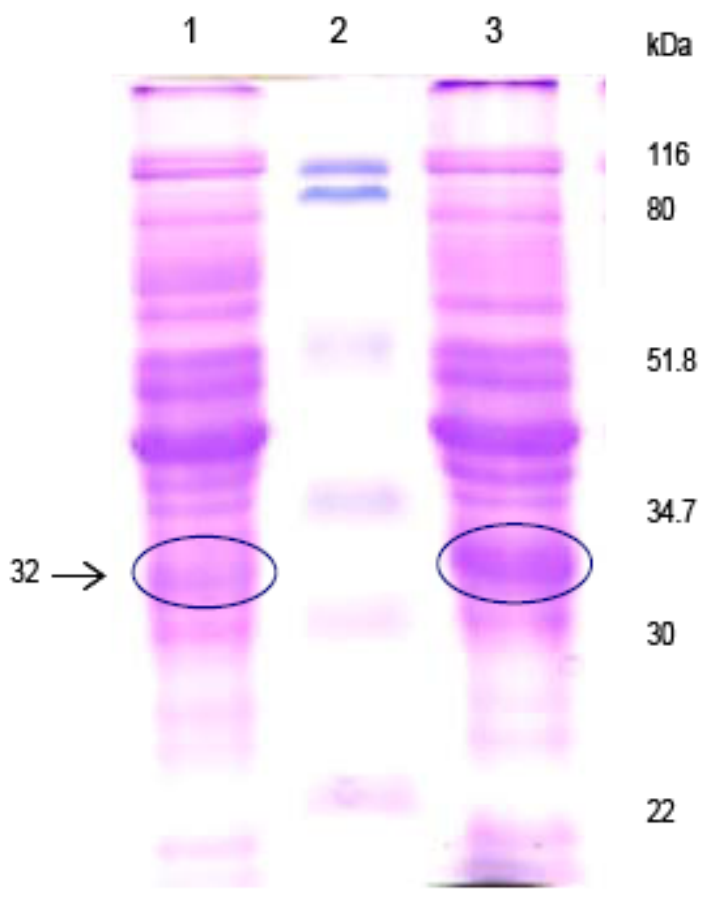

FIG. B.4. SDS polyacrylamide gel electrophoresis of cellular proteins from C. tyrobutyricum. (Lane 1: PPTA-Em mutant; Lane 2: Molecular weight markers; Lane 3: Wild type.) The mutant PPTA-Em had a $32 \mathrm{kDa}$ (approximate) band with greatly reduced expression as compared to that of wild type. 



FIG. B.5. Two-dimensional protein electrophoresis maps of cell extracts of C. tyrobutyricum wild type (top) and mutant PPTA-Em (bottom). The horizontal axis shows the approximate PI range of IEF step. The vertical axis shows the approximate molecular weight. 


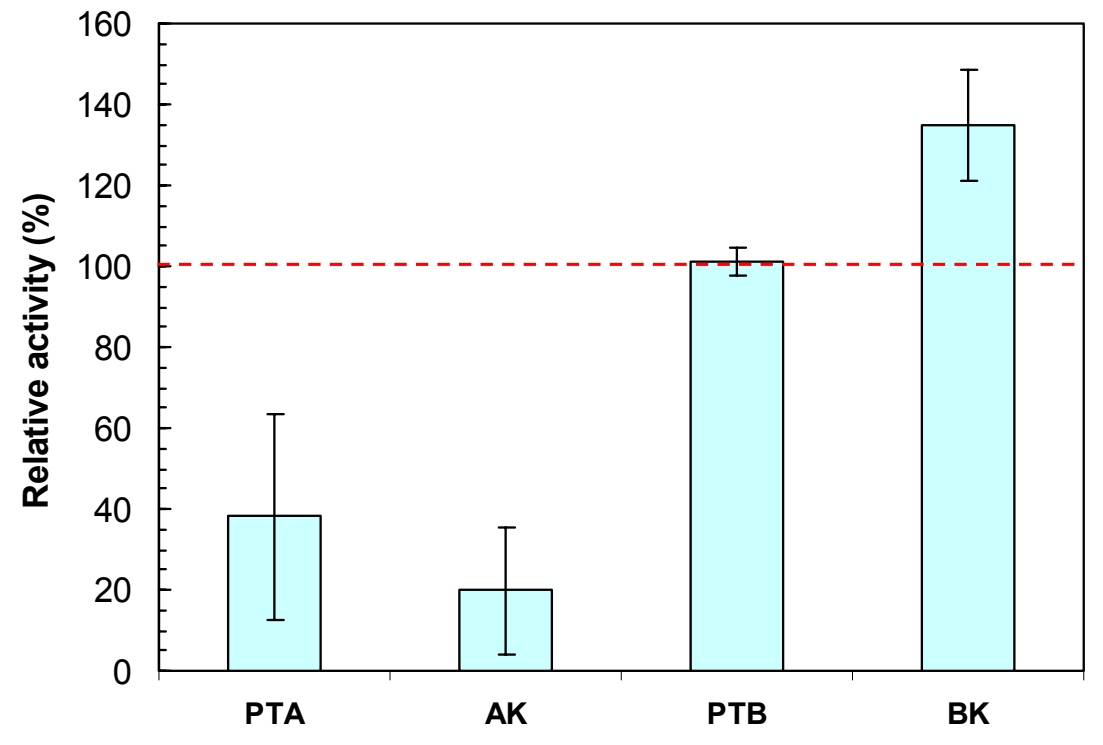

FIG. B.6. Relative activities of key enzymes in acetate and butyrate-forming pathways in the PPTA-Em mutant as compared with the wild type. All enzyme activities in PPTA-Em are expressed as the percentage of the specific enzyme activities in the wild-type of $C$. tyrobutyricum ATCC 25755. 

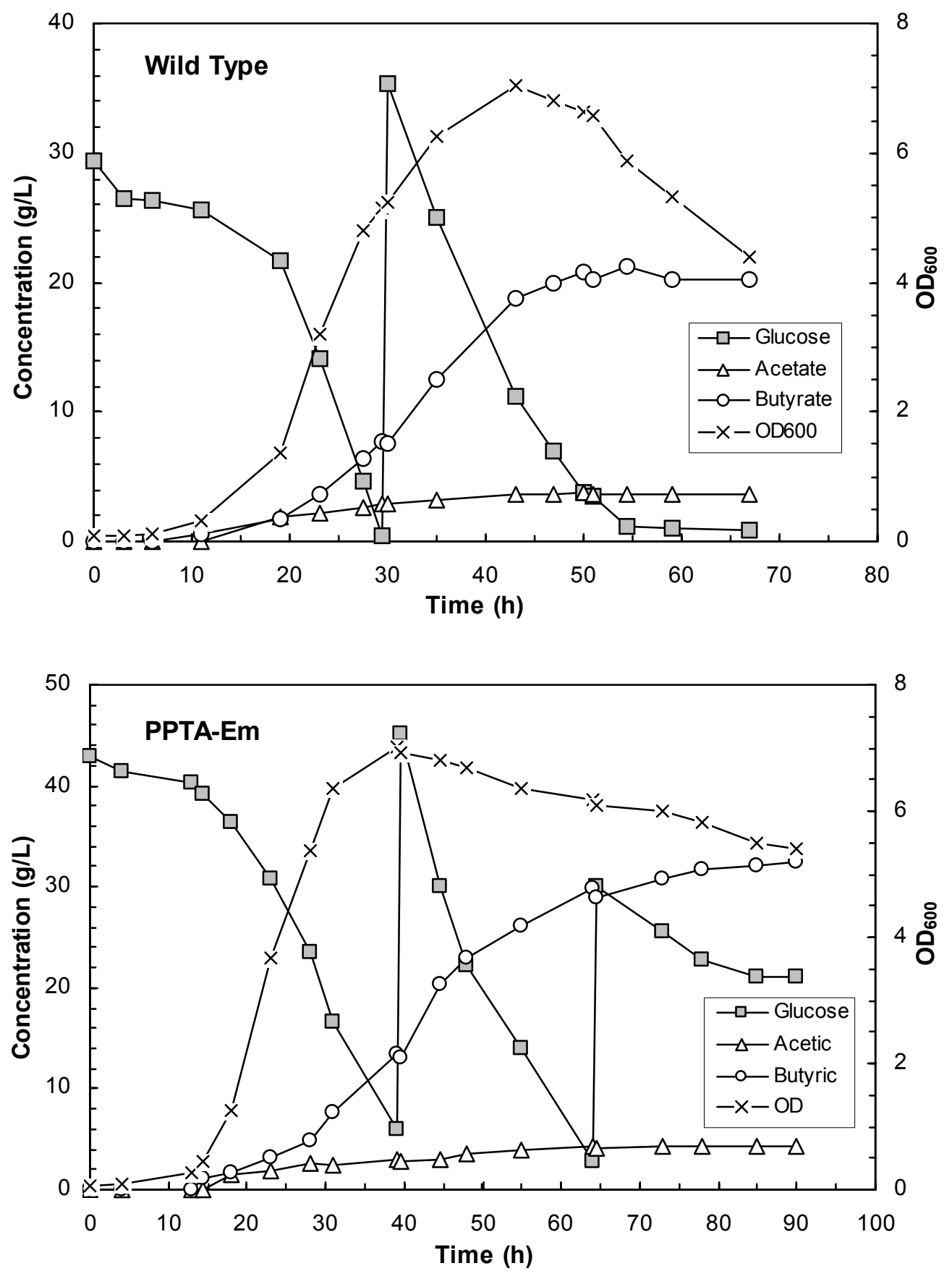

FIG. B.7. Fermentation kinetics of $C$. tyrobutyricum wild-type (top) and pta-deleted mutant (bottom). The fed-batch fermentations were carried out in a $5-\mathrm{L}$ fermentor at $37^{\circ} \mathrm{C}, \mathrm{pH} \mathrm{6.0}$. $\mathrm{OD}_{600}(\times)$, glucose concentration $(\bullet)$, butyrate concentration $(\circ)$ and acetate concentration $(\Delta)$. 


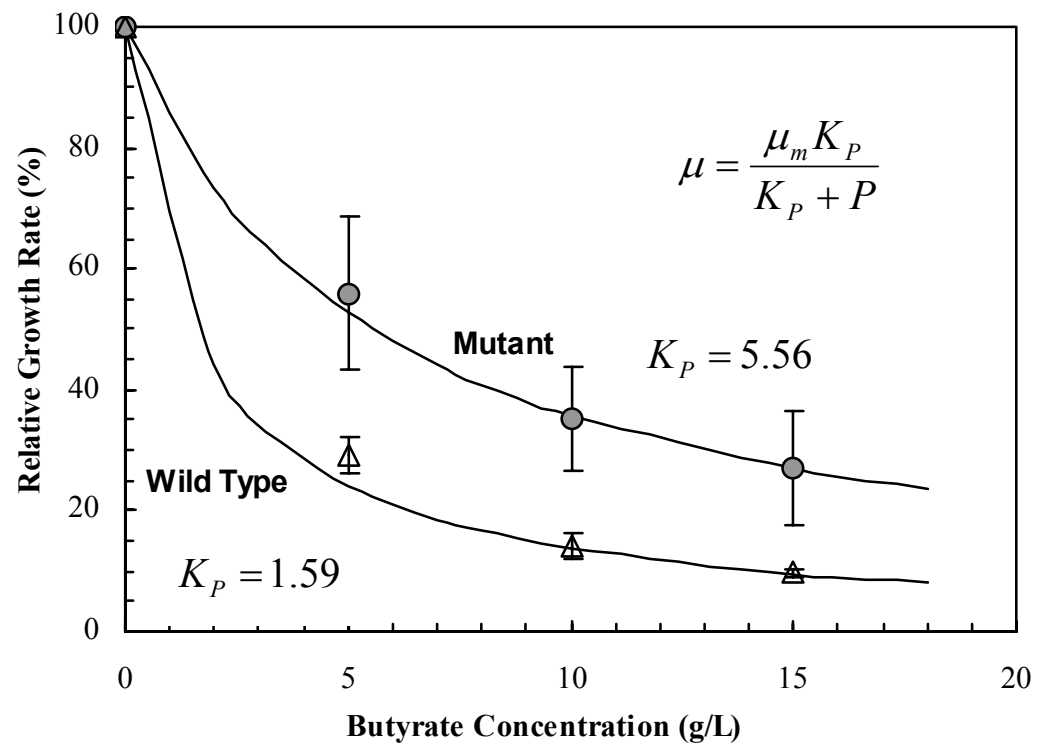

FIG. B.8. Noncompetitive inhibition of butyric acid on cell growth of $C$. tyrobutyricum wild type $(\Delta)$ and PPTA-Em $(\circ)$. The relative specific growth rate with the one at zero butyrate concentration being $100 \%$ was used here for easier comparison between the wild type and the mutant. 


\section{Optimization and Scale-Up of Fibrous Bed Bioreactor}

Cell immobilization has been studied in the laboratory during the last 20 years as a method to improve the performance and economics of many fermentation processes. Fibrous matrices have been developed as the media for cell immobilization because of its high specific surface area, high void volume, low cost, high mechanical strength, high permeability, and low pressure drop. The fibrous bed bioreactor (FBB) with cells immobilized in the fibrous matrix packed in the reactor has been successfully used for several organic acid fermentations, including butyric acid in Phase I, with greatly increased reactor productivity, final product concentration, and product yield. Other advantages of the FBB include efficient and continuous operation without requiring repeated inoculation, elimination of cell lag phase, good long-term stability, and easier downstream processing. The great reactor performance of the FBB can be attributed to the high viable cell density maintained in the bioreactor as a result of the unique cell immobilization mechanism within the porous fibrous matrix. Conventional immobilized cell fermentation usually lose fermentation productivity over a long operation period when the cells are used continually or repeated in a continuous or fed-batch fermentation, due to limited mass transfer and accumulation of dead cells. Reactor clogging and channeling often happen, resulting in deteriorated reactor efficiency and consequently an inoperable reactor. Therefore, for stable long-term operation of the bioreactor, cells in the reactor must be continuously renewed to maintain high productivity and to prevent reactor or culture degeneration. Aged, non-viable and non-productive cells are removed immediately and cell density in the bioreactor is controlled to avoid clogging.

Understanding the mechanism and factors controlling cell immobilization in the FBB is the first step in optimizing and scaling up the bioreactor for industrial applications. Hydrodynamics and mass transfer in the fibrous bed are affected by the fibrous bed packing design, and are critical to the fermentation performance. These were investigated so that the reactor was properly scaled up. Also, the feasibility of engineering and construction of a large-scale fibrous bed bioreactor was also evaluated and carried out.

\section{Cell immobilization (adsorption) on fibrous matrix}

Cell immobilization on fibrous matrices can occur in three stages: transport of cells from the bulk phase to the fiber surface, adhesion of cells to the surface, and subsequent colonization along the surface. Cell-support adhesion is the key step in controlling cell immobilization in the FBB and is thus the focus of this study. It is governed by non-specific physicochemical interactions and by more specific adhesin-receptor binding events. Since the fibrous materials used in the FBB are essentially inert to the cells, attention was focused on non-specific factors only and the cells adhering to the substrates can be regarded as colloidal particles.

The physicochemical forces of attraction and repulsion include long-range forces, e.g., electrostatic interactions and van der Waals forces, and short-range interactions, e.g., dipole interactions, chemical bonding, and hydrophobic interactions (McEldowney and Fletcher, 1986). Most gram-negative and many gram-positive bacteria are negatively charged, as are many solid surfaces. As a result, electrostatic repulsion between the bacteria and solid surfaces prevent their contact. If the microbial cells and the substratum come close together (ca. $<0.4 \mathrm{~nm}$ ), short range 
forces are particularly important (Tadros, 1980). A short-range force which has been implicated in microbial cell adhesion is hydrophobic bonding, which involves the interaction of non-polar groups on opposing surfaces. Hydrophobic interaction can be described by surface free energy/hydrophobicity theory (Kober et al., 1995). Usually, greater hydrophobicity of cells and substrates cause greater attractive forces, resulting in a higher degree of adhesion (Rosenberg, 1991). There are many cell-surface components that influence cell hydrophobicity (Rosenberg and Kjelleberg, 1986) including thin fimbriae, $M$ protein, lipoteichoic acid, A protein, prodigiosin and so on. Components of the cell surface usually vary greatly as function of growth conditions.

Whether cell adhesion could happen on solid surfaces depends on the balance between opposing attraction and repulsion forces in both electrostatic and hydrophobic interactions. As a result, factors affecting surface hydrophobicity and surface charge of both cells and supports can result in a change of cell-support adhesion. These include the growth conditions of cells, media constituents, environmental factors, such as $\mathrm{pH}$, inorganic salt concentration, and surfactant concentration, and modification on support surface can also influence cell adhesion greatly.

Adhesion of $C$. tyrobutyricum and $C$. acetobutyricum on two commonly used fibrous materials, cotton towel and polyester fabric were studied. Physical and chemical modifications of the supports and their effects on cell immobilization were evaluated to optimize cell adsorption. Various factors affecting cell adhesion were studied, including shear rate, culture age, and different components in the media. The effects of $\mathrm{pH}$ and ionic strength on cell adhesion were measured to study the role of electrostatic interaction. The effect of hydrophobic interaction was also investigated by determining the effects of different surfactants (including a concentration series of Triton X-100) on cell desorption.
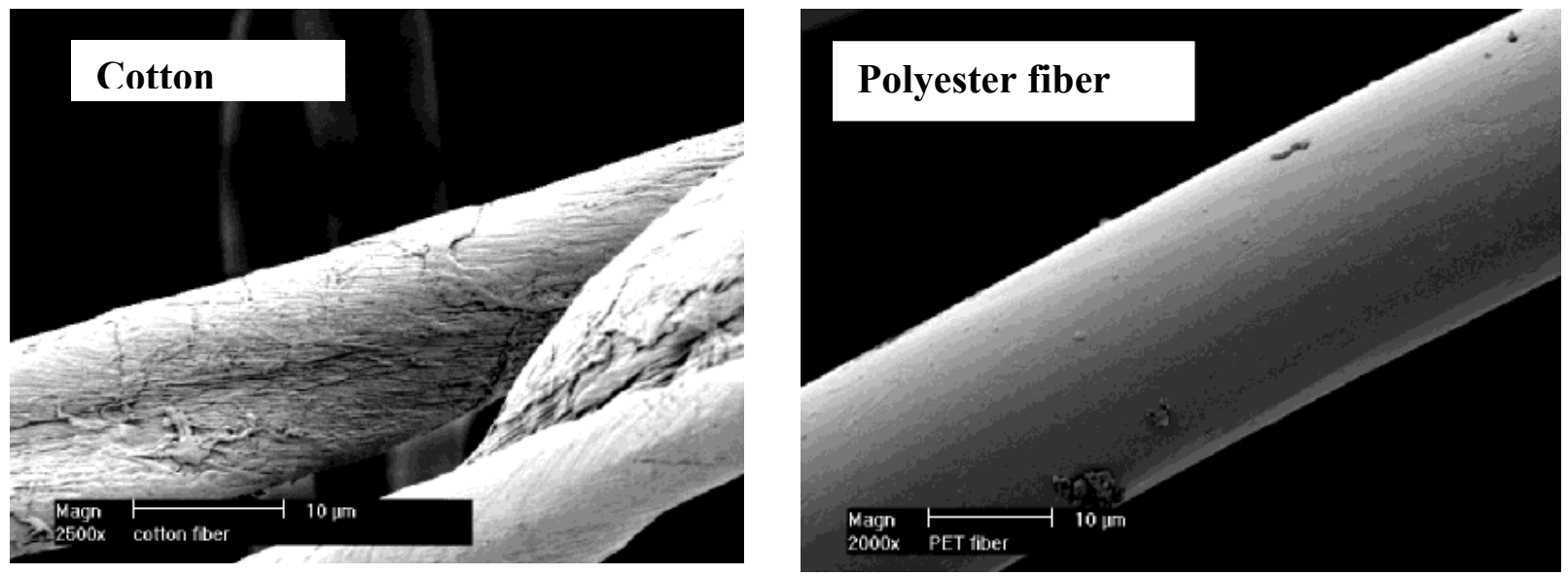

As can be seen in the above SEM photos, cotton fibers have a rough surface and polyester fiber has a smooth surface. Consequently, cells usually adsorb better on cotton fibers than on synthetic polyester fibers. However, with proper surface modifications, both cotton and polyester can give high cell adsorption rates and capacity, which are desirable for immobilization of bacterial cells for high-density fermentation. The following figure shows the adsorption kinetics for typical bacterial cells. 


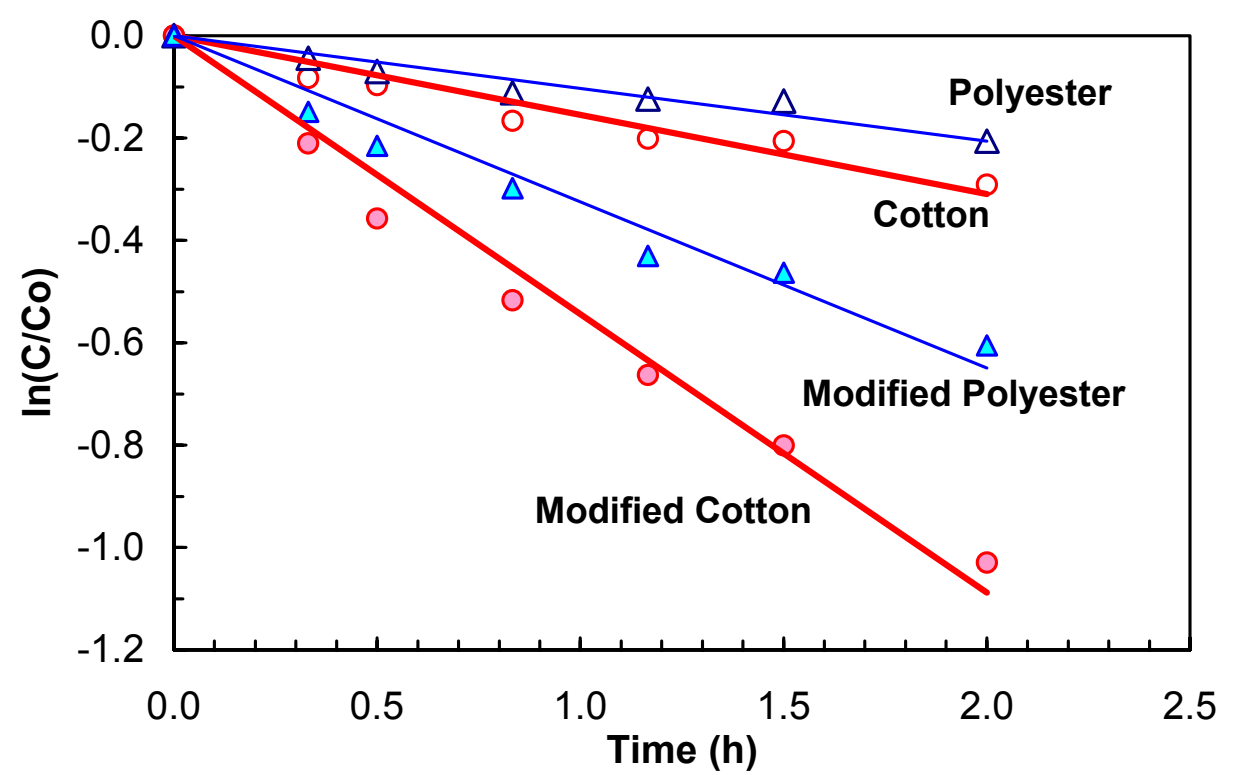

Figure C.1. Adsorption of bacterial cells on cotton and polyester fabrics. The adsorption rate is dependent on the cell concentration (Co), following the first-order reaction kinetics, and the substrate surface properties. The slope of each line is corresponding to the adsorption rate constant, with the steeper slope indicating a faster cell adsorption.

It is noted that cell adsorption on fiber surface is a reversible process, allowing continuing renewal of cells immobilized in the fibrous matrix. Although cotton is generally better than polyester for bacterial cell adsorption, polyester is non-biodegradable and cheaper and stronger than cotton. Final selection of the fibrous materials for the FBB was based on the adsorption/desorption performance of the materials studied.

\section{Design and construction of fibrous bed bioreactor}

A high cell density and high mass transfer rates are desired for the fermentation. The fibrous-bed immobilized-cell bioreactor was optimized in its packing design to achieve best performance in hydrodynamics and mass transfer that affected cell growth (density) and fermentation kinetics. In the laboratory fibrous-bed bioreactor, cells are immobilized in a spiral-wound, fibrous matrix that provides large surface areas for cell attachment and large void spaces for cell entrapment to achieve high cell density ranging from $40 \mathrm{~g} / \mathrm{L}$ to $100 \mathrm{~g} / \mathrm{L}$. Cell growth in the fibrous matrix is controlled by the supply of growth nutrients present in the fermentation medium. The bioreactor can be operated either continuously or as repeated batch and fed-btach for a prolonged period due to continued cell renewal. The large built-in vertical gaps among the spiral-wound layers of the fibrous matrix allow gases, such $\mathrm{CO}_{2}$ and $\mathrm{H}_{2}$ produced during the acidogenesis period, to flow upward freely and escape from the top of the reactor to avoid pressure built-up, and the liquid medium to be pumped through the reactor bed without substantial pressure drop.

The following diagram illustrates the basic design concept of the fibrous bed bioreactor, which is basically a column vessel packed with spiral wound fibrous matrix with built-in 
flow channels between layers of fibrous matrices to allow fluid and particles (suspended solids) flowing through the fibrous bed in the axial direction. The highly porous fibrous matrix has large surface area and void volume to allow high densities of cells to be immobilized by either natural attachment or entrapment or both. Gaps between the matrix layers, as flow channels, allow for free flow of fermentation broth, suspended solids, and gases to the reactor outlet while inert particles, including excess dead cells, fall to the bottom of the reactor where they are continually removed. The fibrous bed bioreactor is novel in its packing design and advantageous in its ability to immobilize a high density (up to $\sim 100 \mathrm{~g} / \mathrm{L}$ ) of producing cells while circumvents clogging and fouling problems commonly occurring to conventional immobilized cell bioreactors (packed bed, encapsulated bead and membrane bioreactors). Consequently, the fibrous bed bioreactor has stable long-term performance over its entire operation period (over several months to a year in our previous testing) even with a feed stream containing suspended solids (e.g., starch granules and corn fibers). This attribute is particularly important when "dirty" byproduct streams from corn milling plants are used as the feedstock for fermentation. Because of the high cell density in the FBB, contamination is not a problem after reactor startup and even non-sterile cheese whey permeate can be used as a continuous feed to the reactor as has been shown in propionic acid and lactic acid fermentations (Silva and Yang, 1995; Huang and Yang, 1998).

\section{Convoluted Fibrous Bed Bioreactor}

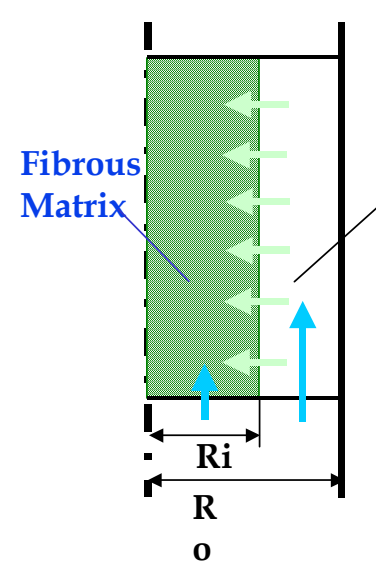

Fluid

Free

Flow

Channel

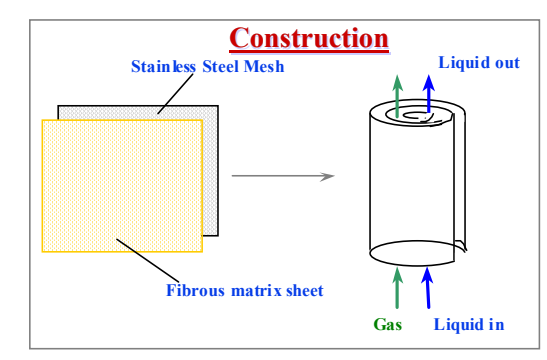

Volumetric Mass (Oxygen) Transfer Rates

- Diffusion $-10^{-6}$ to $10^{-5} \mathrm{~mol} / \mathrm{m}^{3} / \mathrm{s}$

- Axial convective flow $-10^{-4} \mathrm{~mol} / \mathrm{m}^{3} / \mathrm{s}$

- Radial convective flow $-10^{-3} \mathrm{~mol} / \mathrm{m}^{3} / \mathrm{s}$

Fibrous bed bioreactor packing design. Depending on the design, nutrients can be delivered to the cell matrix by both diffusion and convection, which greatly increases the volumetric mass transfer rate, making the reactor one of the most efficient in hydrodynamic and mass transfer.

In this project, we optimized the fibrous matrix design (type of fibrous materials, packing density, and gaps between fibrous layers in the matrix), reactor operating conditions (liquid velocity, $\mathrm{pH}$, etc.) to control the adsorption of cells (desirable producing cells and undesirable dead cells) in the fibrous matrix. The different surface properties from these fiber materials have profound effects on cell immobilization and adsorption (and fouling) of inert solid particles in the reactor, and thus need to be further studied in order to generate optimal reactor performance 
for a given fermentation process. The achievable cell density in the fibrous bed bioreactor is proportional to the packing density. On the other hand, a loosely packed fibrous bed may be necessary to avoid fouling and clogging by inert solids and to allow particles to flow through the fibrous bed without substantial pressure drop. Thus, depending on the feed stream and flow conditions, there is an optimal packing density which provides good gas, liquid, and solid flows, and give the best fermentation performance. It is also important to know the effects of packing density on pressure drop and flow pattern in the fibrous bed. The thickness of the fibrous sheet and gap also need to be optimized because they affect the hydrodynamics and diffusion in the fibrous matrix. A fluid dynamic simulator (FLUENT) was used to simulate the flow environment in the FBB and to predict pressure drop and mass transfer for various packing design.

To scale up the FBB, engineering and construction issues also needed to be considered. In small scale, mixing is not a general concern since it can be accomplished with sufficient liquid recirculation with a pump. For larger scales, mixing can be accomplished by either an internal agitation system or through air-lifting (using $\mathrm{CO}_{2}$ gas generated in the fermentation). For the latter case, the fibrous matrix is packed only in the annular region and gas is pumped through the center of the reactor. The fluid density difference causes liquid to circulate through the matrix. The design of modular constructed matrices for packing for the larger reactors was also evaluated for ease of assembly and disassembly as well as extended life in a 150 liter reactor. Matrix packing also was evaluated for clean-in-place operation.

"Extractive Fermentation Using Convoluted Fibrous Bed Bioreactor," U.S. Patent No. 5,563,069.

A high cell density and high mass transfer rates were established for the fermentation. The fibrous-bed immobilized-cell bioreactor optimized the design and achieved the best performance in hydrodynamics and mass transfer affecting cell growth (density) and fermentation kinetics over free cell fermentations. In the scale-up $(150 \mathrm{~L})$ the fibrous-bed bioreactor, cells were immobilized on a spiral-wound, fibrous matrix that provided a large surface area for cell attachment and large void spaces for cell entrapment to achieve high cell density ranging from $40 \mathrm{~g} / \mathrm{L}$ to $100 \mathrm{~g} / \mathrm{L}$.

Cell growth in the fibrous matrix is controlled by the supply of growth nutrients present in the fermentation medium. We found that a dilution rate of one and a supply of 5\% sugar (corn starch or whey) was best suited for production purposes. Five percent dextrose, corn starch and-or lactose were used and proved very effective.

The DIRCR (Dual Immobilized Reactors with Continuous Recovery - US Patent \# 5,753,474) process was operated continuously - configured with US Patent 5,563,069 - for a prolonged period. 6-9 months and yielded an equivalent of 2.5 gallons butanol per bushel corn - The same as the ethanol industry. This yielded $25 \%$ more energy from a bushel of corn. A calculated $18 \%$ more energy is attained with the hydrogen given off in the acidogenesis reaction. That is $42 \%$ more energy from a bushel of corn over what is attained through the production of ethanol.

Scale up from the $100 \mathrm{ml}$ lab scale to 150 liters proved the scalability and stability of the process. This demonstrated that there were no problems in the procedure and encouraged us to proceed with engineering work for a larger process. 


\section{Develop Separation Techniques for Butanol Recovery from Fermentation}

Butanol, is the desired end product of the fermentation, was found to have several harmful effects on C. acetobutylicum. At a concentration high enough $(\sim 15-20 \mathrm{~g} / \mathrm{L})$ to inhibit growth, butanol destroyed the ability of the cell to maintain internal $\mathrm{pH}$ (which consequently dissipates the $\mathrm{pH}$ gradient across the cell membrane), lowered the intracellular level of ATP, and inhibited glucose uptake (Bowles and Ellefson, 1985). Therefore, was desirable to develop an effective butanol recovery technique to improve the fermentation performance.

A variety of product recovery techniques including adsorption, gas stripping, pervaporation (extraction via a membrane), liquid-liquid extraction, perstraction and reverse osmosis (Maddox, 1989) were evaluated. While adsorption, gas stripping, and reverse osmosis have been proved to be able to improve the fermentation performance by removal of the inhibitory products (Maddox, et al., 1994; Yang, et al., 1994; Yang and Tsao, 1995), extensive studies have been conducted with pervaporation and liquid-liquid extraction (including perstraction). Among the membranes that have been tested for pervaporation, silicone membranes have been selected and proved to be an effective product removal method (Favre and Nguyen, 1996; Larrayoz and Puigianer, 1987; Geng and Park, 1994; Groot et al., 1991) but have since proved to be uneconomical. Liquidliquid extraction, usually are membrane-assisted, has been most widely used because of its high efficiency in solvent removal and its convenience in integrating with the fermentation process (Qureshi and Maddox, 1995). Among various extractants examined, oleyl alcohol and polypropylene glycol are the most suitable extractants (Barton and Daugulis, 1992; Davison and Thompson, 1993; Jeon and Lee, 1987; Ohno, et al., 1991). By integrating the fermentation process and liquid-liquid extraction or membrane-assisted solvent extraction, substrate consumption has been increased and higher yield and productivity for butanol were obtained (Groot, et al., 1990; Jeon and Lee, 1989).

Downstream processing including various separation methods for butanol recovery were evaluated. Pervaporation (partial vaporization through a dense membrane), stripping with $\mathrm{CO}_{2}$, adsorption, and solvent extraction was evaluated for their feasibility for butanol separation and recovery from the fermentation broth.

In collaboration with Taasi, Inc. of Delaware, Ohio, we developed a sol-gel adsorbent for butanol separation. Our data indicate that this new adsorbent is more advantageous than conventional ones and has good potential for butanol separation while rejecting butyrate and recovery from the fermentation broth. We tested four "Selective Adsorbent" materials for use in removal of acids, and the data showed the ability of one sample to selectively remove acetic and butyric acids from the fermentation broth (see the following Figure D.1) and letting butanol pass. Similarly, butanol was selectively removed by choosing a different adsorbent material. Desorption is to be accomplished by hot air stripping and condensation, very similar to using an activated carbon recovery systems. It is anticipated that butanol can be high graded in this manner and then decanted with only $10 \%$ water content in the phase separation modality. The decanted liquid can then be distilled to remove only $10 \%$ water and not $98-99 \%$ water found in the historic ABE fermentation. 


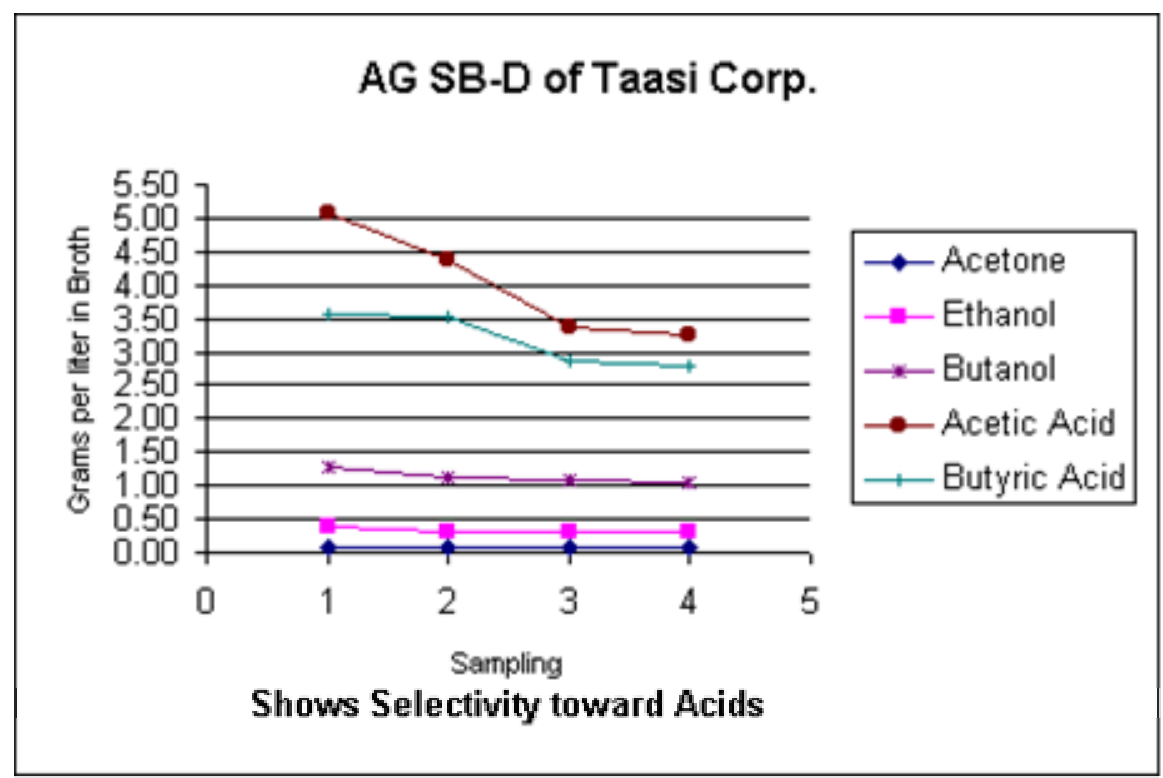

Figure D.1. Adsorption of various components present in $\mathrm{ABE}$ fermentation broth. The data shows a high selectivity toward acids with AG SB-D. Other adsorbents were used for separation of butanol.

We further developed a stripping tower process where vapors of butanol and water were passed through activated carbon or simply condensed and decanted. Gas stripping allows for butyric acid to remain behind in the broth for further conversion to butanol. When breakthrough occurred in the activated carbon the carbon was back stripped and the gases condensed for decanting and then purification via distillation. The energy usage and cost of equipment plus replacement cost for spent activated carbon has led us to look at a simpler process of stripping and decanting the liquid and then distill off less water. This is all done with skills known to the art.

\section{E. Fermentation Process Study}

The two-step fermentation process was tested first with a small laboratory unit to fine-tune some of the process parameters. Later, a small pilot scale process (see the following diagram) was built and tested to evaluate the feasibility and performance of the process for butanol production form glucose (dextrose) and butyrate. It is noted that the design shown in the following diagram is not final and is mainly for illustration purpose. For example, the relative size of the two FBB were dependent on the relative volumetric productivity in each of the two fermentation steps. The design also was modified to an extractive fermentation operation for the butanol production step. We intended to perform the process evaluation in a pilot scale $-250-1,250$ gallons per week butanol. Unfortunately, due to unexpected delays and other problems, this study was not completed during this project but the work completed showed great improvements over pervaporation and other modalities. We will continue this study in Phase III, with additional funding from private investors. 


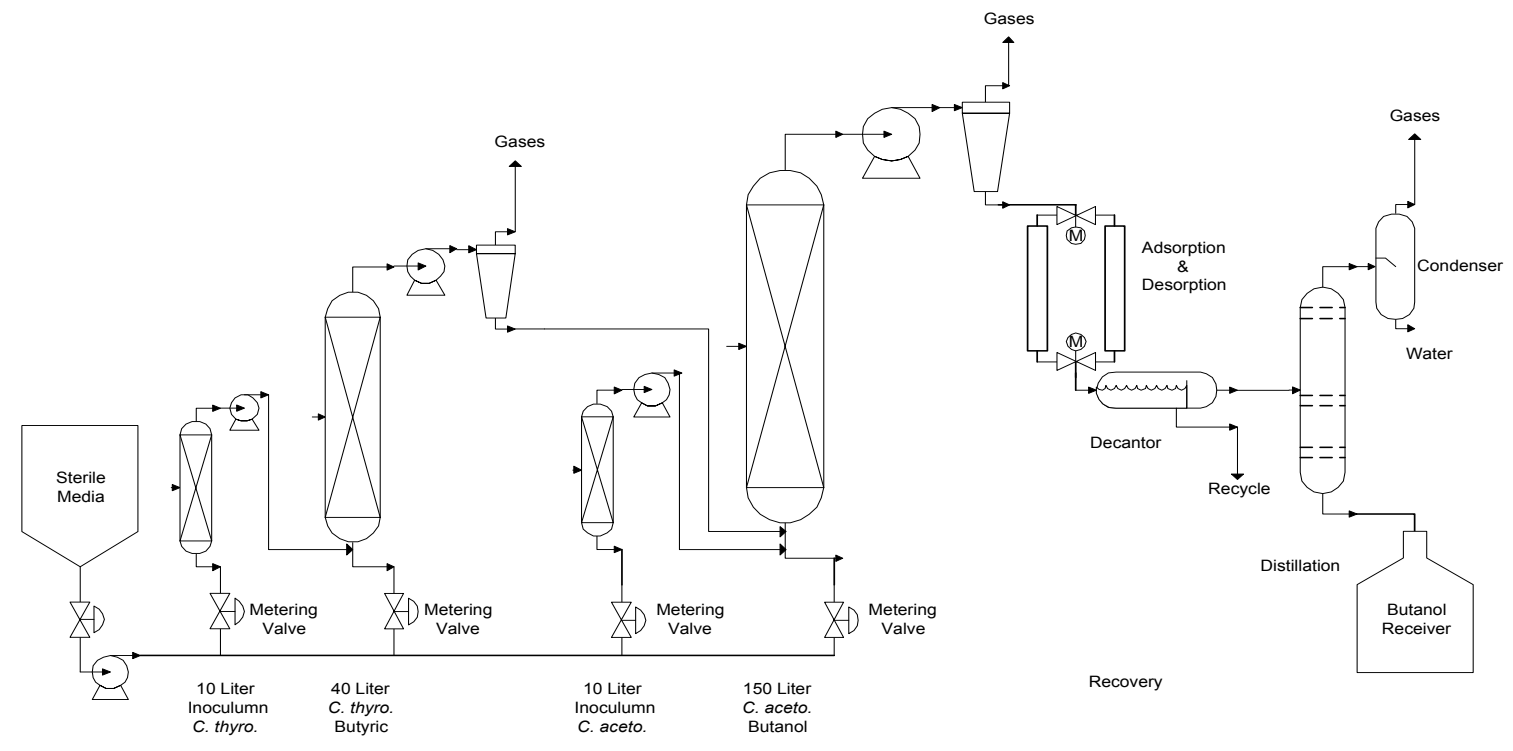

Schematic of Dual Stage Butanol Prototype with Adsorption / Desorption Recovery

Media is prepared in a sterile fashion from corn meal and hydrolyzed by enzymatic conversion and fed proportionally to the different reactors. Inoculums for each is established independently and fed as necessary to the respective reactor. The first stage reactor ( 40 Liter) converts the majority of feedstock media to butyric acid, which is clarified via hydrocyclone, and the resultant liquid flow is fed to the second reactor $(150$ Liter) for the final production (conversion) to butanol. The effluent from this reactor is clarified via hydrocyclone and passed through a selective adsorbent that removes the butanol and reject the butyric acid (which is returned to the 150 Liter reactor for further conversion to butanol). The butanol is desorbed when breakthrough occurs and is condensed from hot gas stripping (not shown) and decanted. The decanted butanol is further purified by distillation and collected for shipment.

\section{F. Scale Up to a Prototype Demonstration Plant}

The process drawings for a prototype demonstration plant allowed us to design our Technology Development Centers Biorefinery for a Dual 40/80/120 liter process and to expand it to 250 and 1,250 gallons butanol per week process for Pre-Commercial Pilot Plant studies. (Work still in progress) This is part of the package to introduce the concept to prospective investors. Estimated costs for a thousand gallons per week are $\$ 1.3$ million. 


\section{Process Drawing for DIRCR process Feedstock unloading, storage, sterilization, CIP, Dual Reactors, and recovery.}

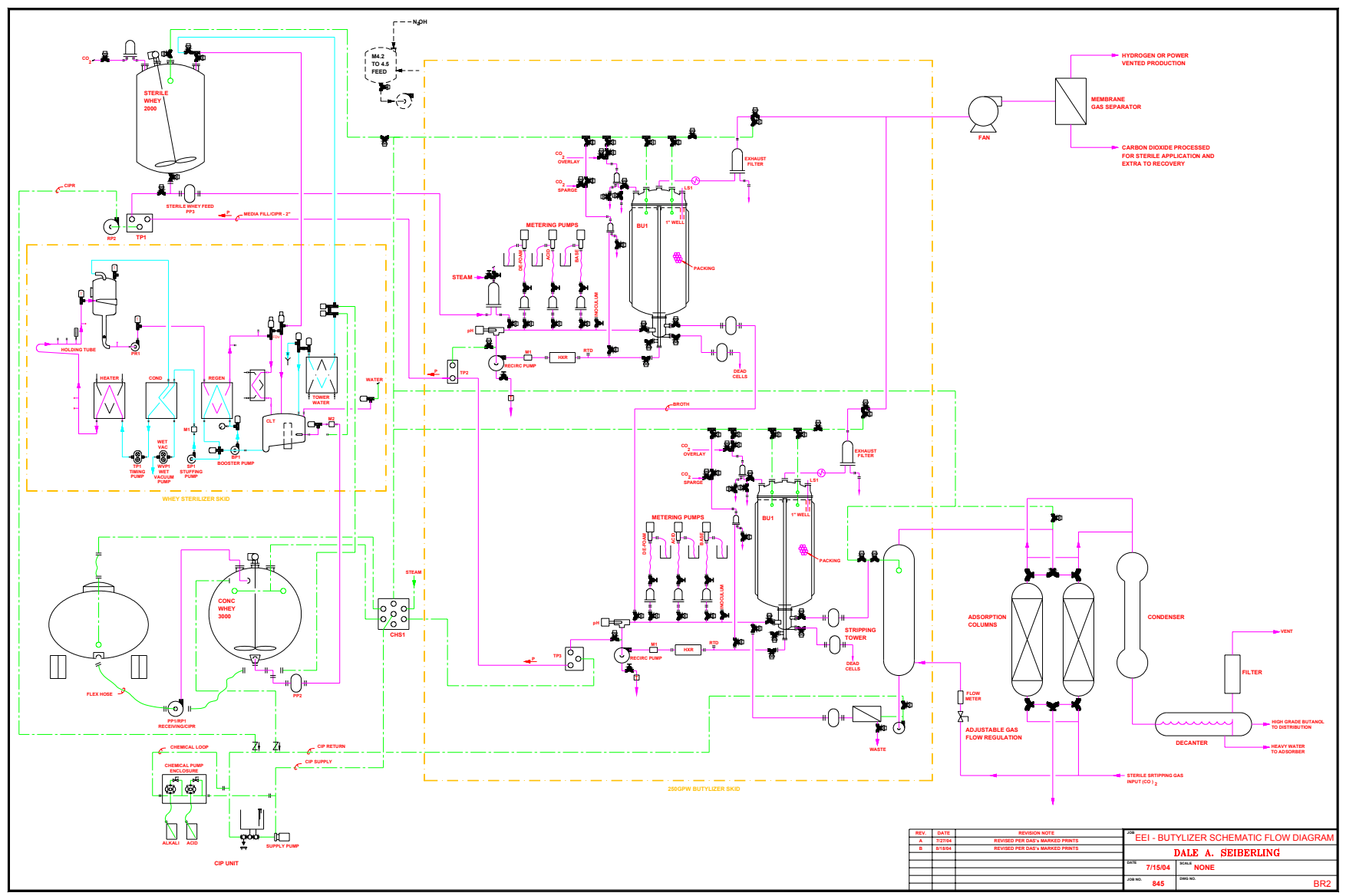

\section{EEI's Patent for Butanol Production by Fermentation}

The Company's 'Dual Immobilized Reactors with Continuous Recovery' (DIRCRTM) Process is covered by U.S. Patent No. 5,753,474 and is shown in Figure F.1 with a proprietary recovery modality.

The Company's patent for butanol production by fermentation is based on the use of two separately immobilized cultures: Clostridium tyrobutyricum and Clostridium acetobutylicum. In the first stage the biomass being processed is converted to butyric acid, carbon dioxide and hydrogen. In the second stage, the butyric acid is converted to butanol. In this manner no ancillary products, as are produced in the historic ABE fermentation are created and only butanol is produced. 


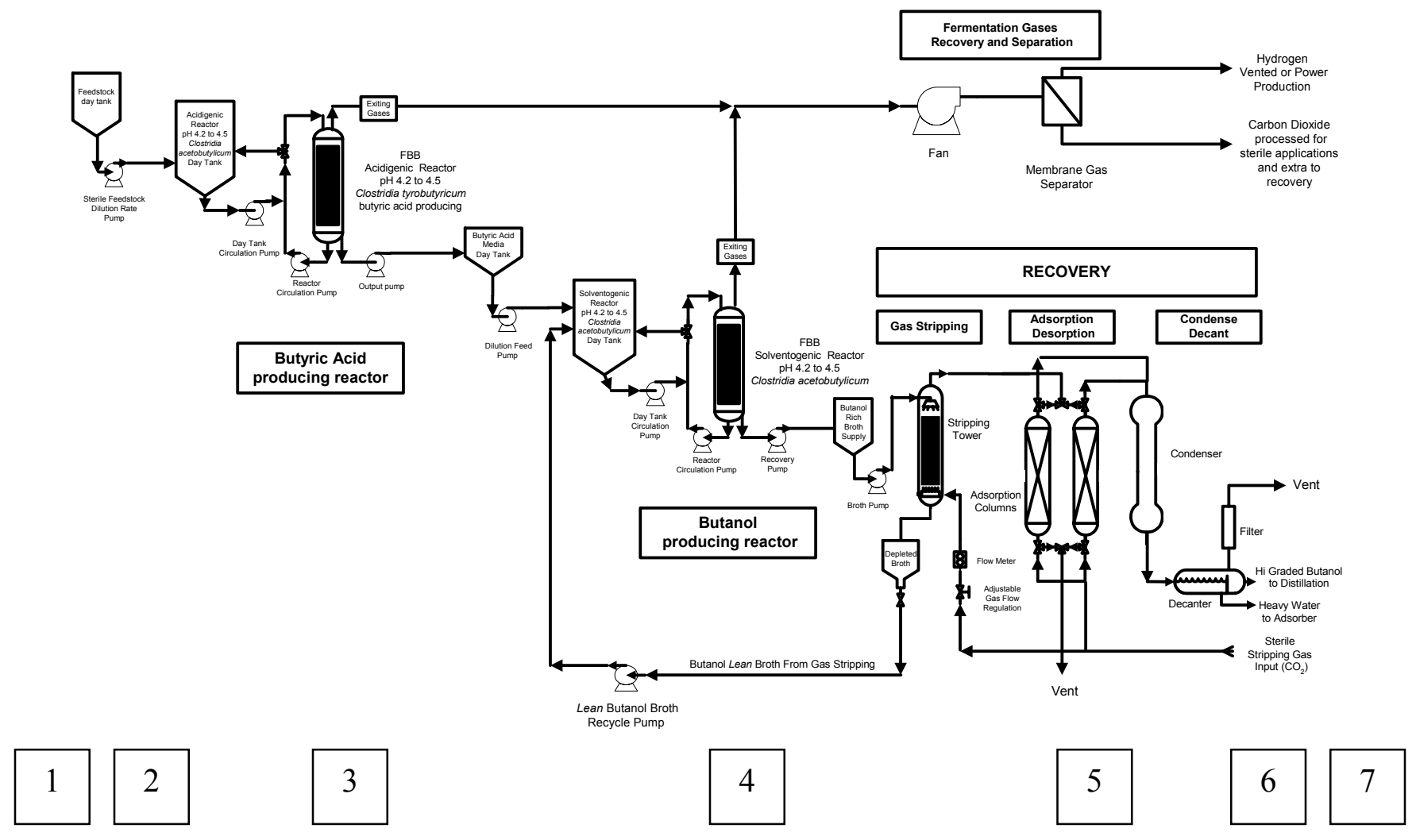

Figure F.1. The Dual Immobilized Reactors with Continuous Recovery (DIRCR ${ }^{\mathrm{TM}}$ ) process.

\section{DIRCR ${ }^{\mathrm{TM}}$ Process Description}

As noted in the production of butanol consists of a seven-stage process:

1. Dry or wet milling

2. Conversion of biomass into usable sugars

3. Butyric acid and hydrogen fermentation (acidiogenic)

4. Butanol fermentation (solventogenic)

5. High grading: gas-stripping/adsorption/desorption/condensing/decantation

6. Distillation: high purity

7. By-product recovery

Any front-end material handling technology that is applicable to biorefinery production can be used in the DIRCR ${ }^{\mathrm{TM}}$ process. When whey permeate is used as a feedstock, steps 1 and 2 are eliminated and $23 \%$ savings in capital equipment costs for feedstock preparation is not required. When whey is used another $40 \%$ in overheads for the cost of corn as in industrial fermentations are removed making the process very economical. 
The dual fermentation process takes advantage of the separate natures of two distinct anaerobic bacteria. One bacterium produces butyric acid (3) and the other converts that acid into butanol (4). During the DIRCR ${ }^{\mathrm{TM}}$ process carbon dioxide and hydrogen are given off and are separated via a membrane and the hydrogen yields another $18 \%$ Btu's.

Butanol is an alcohol that is stripped from the broth in a stripping tower with counter current flows of broth and sterile carbon dioxide or steam (5). The broth falls gravitationally while warm sterile carbon dioxide (steam) passes upward, removing small amounts of butanol, leaving butyric acid for further conversion and then passes butanol ladened vapors into an activated carbon adsorption bed where the butanol is adsorbed from the vapors and butanol-lean water is recycled. Full of adsorbed butanol this canister is exchanged for another recharged (empty) one and the butanol-full canister is stripped (desorbed) by another stream of warmed carbon dioxide. This butanol rich vapor stream is then condensed. The condensate is allowed to settle - decant phase separate. Butanol separates at a $10-15 \%$ concentration, which is to say the floating portion only contains $10 \%$ water and that can be removed by distillation (6).

\section{Purification of an Aqueous Butanol Solution using Azeotropic Distillation}

Normal butanol forms an azeotrope with water that in the past has provided challenges to production of the pure product from an aqueous solution. The azeotrope composition is $55.5 \%$ butanol and $45 \%$ water overall and forms a constant boiling mixture of $93 \mathrm{C}$, which is lower than each of its components butanol and water $(117 \mathrm{C}$ and $100 \mathrm{C}$ respectively). Other distillative separation processes utilize an extractive distillation requiring 2 columns, the first to absorb the water from the butanol azeotrope and the second to regenerate the water entraining chemical used in the first column. 1) Extractive distillations are energy intensive. Also, since a large percentage of the azeotrope is water, both the amount of chemical extractant required and the size of the regenerative column add significantly to the processing costs.

EEI's novel process takes advantage of the fact that the $55 \%$ Butanol azeotrope separates into two liquid phases upon setting. The upper layer constitutes $71.5 \%$ of the total volume and is $79.9 \%$ butanol while the bottom layer represents the remaining $28.5 \%$ of the volume but is only $7.7 \%$ butanol. Decantation of the top layer therefore permits an increase in concentration of $24.4 \%$ in the butanol process stream with no additional energy expended. The process uses 2 distillation columns and a decanter to extract butanol from an aqueous solution. The first column drives the $93 \mathrm{C}$ azeotrope out the top of the column and removes the majority of the water out the bottoms, eliminating the need to vaporize water and drive it out the top of the column. The vapor out the top of column is condensed, fed to a decanter which is used for reflux feed to the first column. The bottom layer from the decanter ( $7 \%$ butanol) is fed back into the feed stream of the first column. The top layer from the decanter, which is high in butanol, is fed to the second column. This process stream off the top of the decanter represents almost $96 \%$ of the total butanol fed to the first column (see math below). The second column again drives the $93 \mathrm{C}$ azeotrope out the top of the column, the vapor mass being proportional to the amount of water fed to the column. The high boiling butanol product goes out the bottom, eliminating the need for high temperatures to drive butanol out the top of the column. 
Question: Butanol azeotrope decanter production is 100 gallons/minute. What percent by weight of butanol is in each of the layers?

Top Layer:

71.5 gallons/minute $\times 8.33 \# /$ gal x .849 density $\times 79.9 \% \mathrm{w} / \mathrm{w}=404 \# / \mathrm{min}(95.5 \%$ of total $)$

Bottom Layer:

28.5 gallons/minute x $8.33 \# /$ gal x .990 density $\times 7.7 \% \mathrm{w} / \mathrm{w}=18.9 \# / \mathrm{min}(4.5 \%$ of total $)$

1) Qureshi and Blaschek, "Economics of Butanol Fermentation using Hyper-Butanol Producing Clostridium Beijerinckii ba101", Institution of Chemical Engineers Trans I ChemE, Sept 2000.

\section{SCALE UP}

The Real world impact and limitation in scaling up were felt. The fact that the larger we make the system the more it has to be fed. Continually sterilizing feedstock was the task of the day. Below is a picture of our 150 liter work area with Dr. Wei Cho Huang as manager of the project.

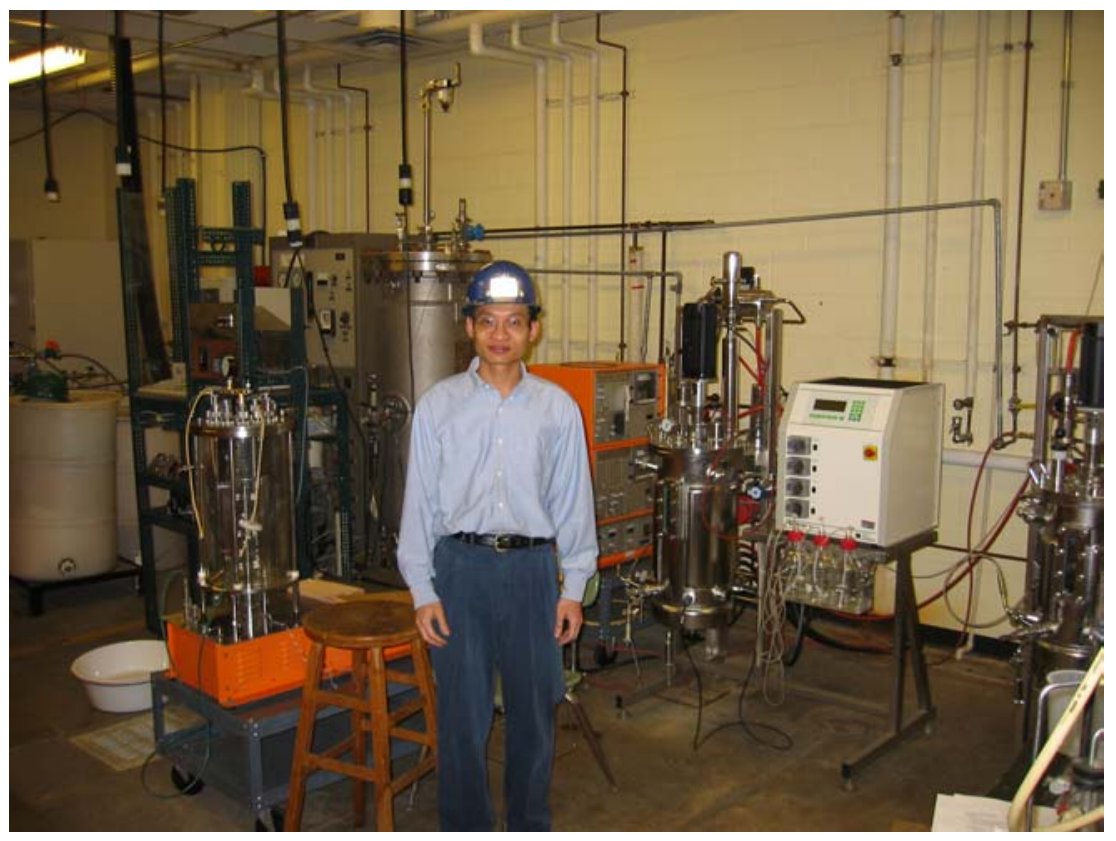

We were able to have two or three prospective investors view our functioning prototype but had to cease after about six months because of the overhead and labor and lack of interest by business. We found it very difficult to find Agribusinesses who were interested in butanol. This is because the general public has not seen butanol used as a 100\% replacement for gasoline in unmodified cars and trucks, nor is butanol even in the NREL data bank as an alternative fuel. Most are interested in our fungal work for L+ Lactic acid and PLA -a biodegradable plastic, and other acids which can be produced with the same equipment and Know-How. One prospect became an investor and gave us matching funds for our grant and allowed us to hire Dale Seiberling to design the biorefinery with Clean In Place system included with the DIRCR ${ }^{\mathrm{TM}}$ (Dual Immobilize Reactors with Continuous Recovery) process. This scale up work proved our 
lab results that we can obtain 2.5 gallons butanol per bushel of corn economically and from whey even more so.

From this point on it was to scale up one more time and two New Brunswick 40L bioreactors were obtained and extended to make them $120 \mathrm{~L}$ each. The first was inoculated with $C$. tyrobutyricum and the second with $C$. acetobutylicum. Runs of 6 months were accomplished at the companies Technology Development Center in Blacklick, Ohio. Many short falls in system design and the cumbersome use of hand actuated valving led to the desire to have a contractor development of LabView (National Instruments) programs for control of the process when additional funds are raised.

Mr. Seiberling was kind enough to help with system design for the next complete system. This process will be scaled to 250 gallons per week butanol and then expanded to 1,250 gallons per week using whey permeate. Additional money (2.5-3.0 million) is necessary to move forward.

Brewster Dairy: This dairy produces Swiss cheese and 2,000,000 pounds of whey permeate per day and is typical of the industry. In order to stay in business they have to deal with their waste stream which is surcharged for the $\mathrm{COD} / \mathrm{BOD}$ by the local municipal sewage system and this is very typical of the industry. They therefore use Ultra High Filtration (UHF) to filter out the butterfat and the protein - processing them and making a profit. Left with whey permeate, this protein deficient stream is not wanted by local farmers to spread on the fields because there is no nitrogen left and the sugar eventually sours the fields. So the Dairy creates dried lactose powder. It costs $33 \phi$ to make and because of the glut on the market usually sell for $22 \phi$ per pound. Even though they are loosing over a million dollars per year it is less than the surcharges that would be incurred. They have agreed to supply all the whey concentrate (22\% lactose) we need for the next scale work.

Whey permeate is a way into the acids and solvent market with essentially free food and at the same time solving an environmental nightmare - disposal of lactose dregs. Our first microbe $C$. tyrobutyricum loved lactose and is the bane of the cheese industry. We realize that ethanol has not been able, over the past thirty years, to solve this disposal dilemma. Currently some ethanol can be made and the only other game in town is to make methane and electricity from whey permeate a tremendous waste of the energy that could be attained through this technology.

Not only can EEI use its technology to produce butyric acid and butanol but by inoculating the reactor with different bacteria we can produce a plethora of green acids, solvents, esters, and salts. This is in compliance with the Strategic Chemicals Act but the market for such products as propionic acid, ammonium and calcium propionate is relatively small. Since a 5 million pound of whey permeate per day process can easily saturate these markets. Both are used as mold inhibitors in agricultural products from bales of hay to loaves of bread and have a solid market that can grow as 'green' propionic acid is produced.

However if all the whey permeate from the U.S. industry were used to produce butanol the industrial solvent market is still huge and corn and other biomass operations with larger and larger outputs will have to be brought on line. Many ethanol biorefineries can be easily retrofitted for sterile anaerobic clean conditions. See Figure F.2 . All the lactose has a market. 


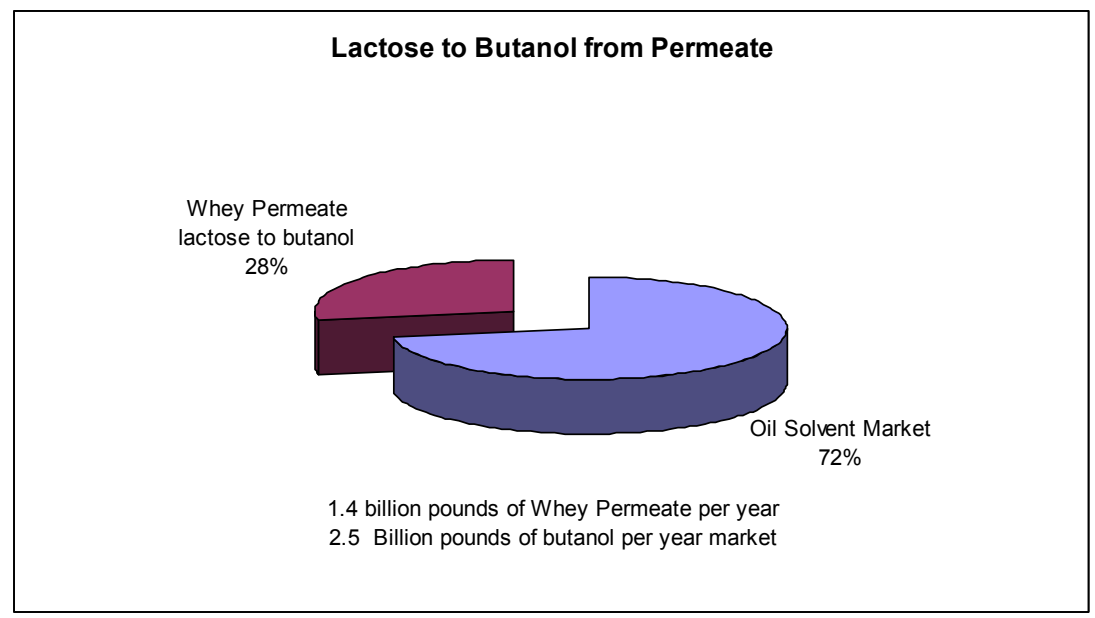

Figure F.2. Industrial solvent market impacted by lactose derived butanol.

\section{G. Economic Feasibility}

The primary objective of this study is to evaluate the technical and economical feasibility for production of butanol as an industrial solvent and secondly as an oxygenate or a 100\% replacement to gasoline from a plant with a capacity of 10 million U.S. gallons per year. The evaluation includes a detailed process design using proven technology and innovative design for scale-up of the immobilize fibrous bed bioreactor, a complete budget estimate of the plant investment including working capital, a detailed analysis of the annual operating cost using corn and whey as the primary feedstock, and a complete financial analysis which establishes butanol selling price required to net to the investor a $15 \%$ discounted cash flow - interest rate of return. This is called the "base case" evaluation.

Some simple comparisons show that Butanol production costs less than ethanol.

- Butanol process uses circulation pumps in its bioreactor whereas ethanol uses large hp motors to stir the mash

- The DIRCR process is continuous whereas ethanol is still batch and requires clean up and restarts every four or five days

- When butanol is made from whey permeate all material handling for storage of grain, weighing, grinding, pulverizing, scarification, hydrolization and sterilizing are required

- When butanol is made from whey permeate $40 \%$ of the annual overhead for cost of corn is eliminated

The butanol biorefinery, in general, uses existing process technology currently employed in grain alcohol plants. The plant operates as a continuous flow process with a Clean-In-Place phased cycle for sterilization of the equipment. 
The novel stripping-condensing and the resulting decantation process was employed to evaluate its economic feasibility to reduce recovery costs using distillation to polish a $10 \%$ water content. Distillation is used in all cases to guarantee an industrial quality product $-99.9 \%$ purity.

All of the utility requirements, with the exception of electricity, and natural gas are produced within the boundaries of the plant. Hydrogen generation as a result of fermentation is expected to offset natural gas consumption by as much as $18 \%$. The possibility of building the plant in Van Wert, Ohio makes access to an Electrical Peaking plants output heat from turbine usage possible, further reducing the heat load on drying DDG's. The turbines exhaust the steam at 150 psig which is suitable for process requirements.

\section{Investment and Operating Costs}

The investment required to build a complete facility for a $10 \mathrm{MM} \mathrm{gal} / \mathrm{yr}$ butanol plant (base case) was determined to be $\$ 1.56 /$ gallon. The investment includes all support facilities and 20 acres of land. Process steam is produced by natural gas which includes flue gas scrubbing equipment.

The annual operating cost per gallon butanol was established at $\$ 0.15 / \mathrm{lb}$. This includes a straight-line depreciation over twenty years. The annual operating costs is rather insensitive to plant investment since the capital investment items (fixed charges) are a small percentage of the total cost. The major cost item is the purchase price of corn and is $40 \%$ of the annual budget. A comparison with current ethanol manufacturing facilities and a similar butanol plant are shown in Figure G.1. Because of the market price for butanol as an industrial solvent, it can be seen that the worst case scenario 10 million gallon per year butanol plant can produce almost two million dollars more net income than an average state of the art 40 million gallon per year ethanol plant. This is a significant advantage for the agricultural community in the creation of value-added products. 


\section{GIVEN A 40 AND 10 MILLION GALLON PER YEAR BUTANOL FACILITY COMPARED TO A 40 MILLION GALLON PER YEAR ETHANOL FACILITY}

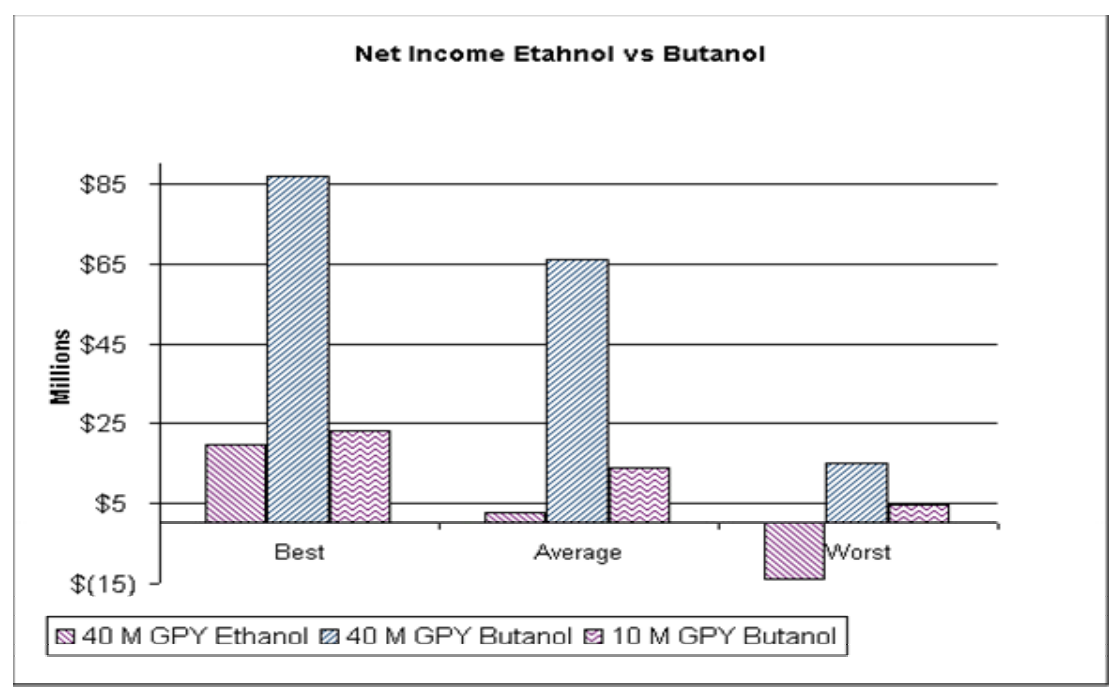

Figure G.1.

\section{Economic Impact of Increased Production of Butanol From Corn}

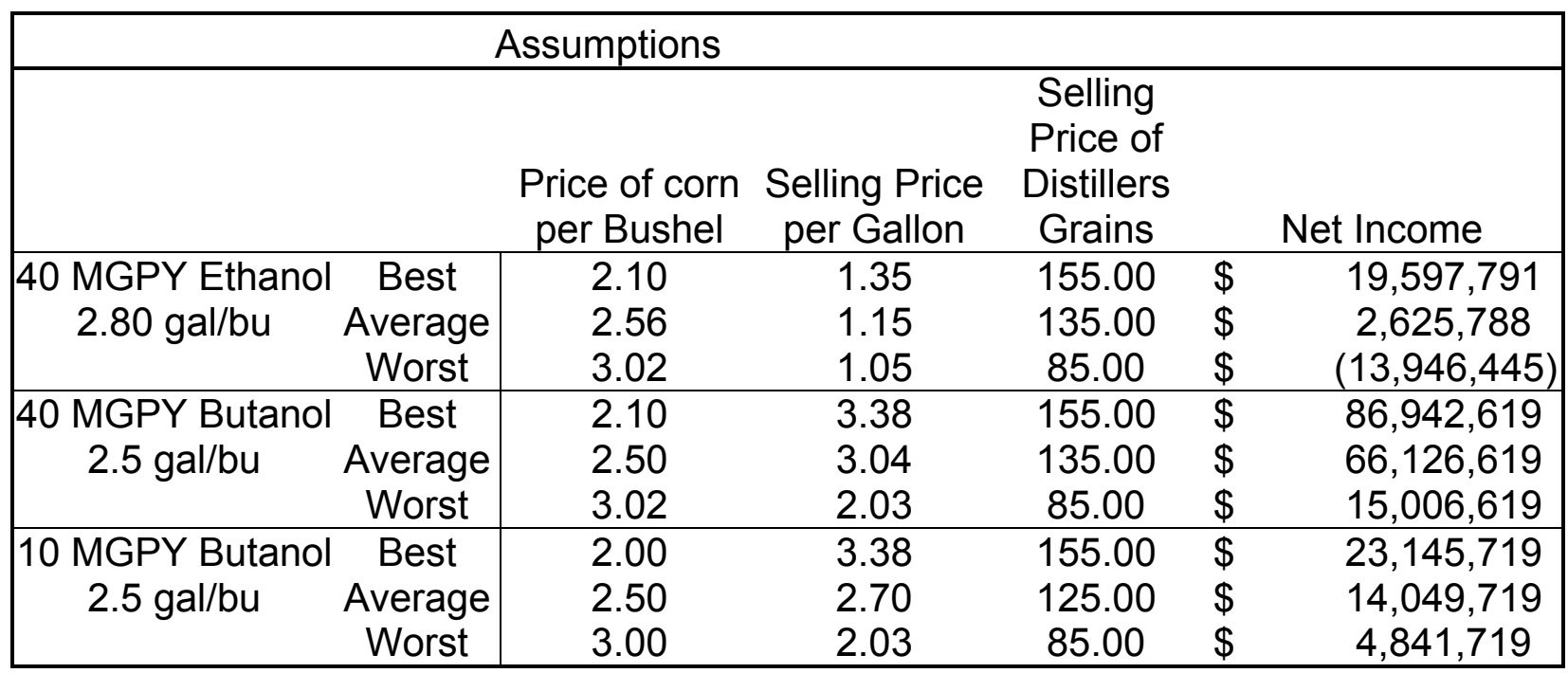

\section{Economic Analyses}

The objective of the economic assessment was to establish a minimum selling price for butanol, which covered the production cost (annual operating expense) and return to the company a realistic return on company equity. This is a base case analyses of $15 \%$ Discounted Cash Flow Interest Rate of Return (DCF-IROR). Since a cash flow analysis includes profits plus depreciation, a $15 \%$ DCF-IROR represents only about a $13 \%$ annual interest rate for a 20 -year plant life. 
The base case selling price was established on a 20 year plant life and a 15\% DCF-IROR. The selling price for butanol varies from $\sim \$ 0.29$ to $\$ 0.50$ per pound, and if competitors want to flood the market the manufacturing and 15\% DCF-IROR are very important to establish. The comparison of ethanol and butanol was established for a high of $\$ 0.50$ and a low of $\$ 0.30$ for that reason and still shows a solid profit for pre Phase II work. Many companies perform their venture analysis based on 10 years because the plant may become obsolete due to new technology prior to the 20 year time period. By building smaller production facilities new technologies can be implemented and retrofitted more easily. The ChemLac business plan is centered on eliminating the cost of corn ( $40 \%$ annual overhead) and using whey permeate as a feedstock. The object is for two 5 million gallon per year butanol biorefineries over a 5 year period to be built. See Appendix B

Various sizes of biorefineries have been designed for the use of whey permeates which are of the 2 to 5 million gallon butanol per year. When compared to various ethanol studies the cost of the fermentation process section runs $15 \%$ more for capital costs. But savings are found in the fact that the process is continuous and eliminates constant clean up and starting of the next batch and large mixing motors for the vats used in ethanol are removed saving electricity. The other boundary value is the selling price - that being 3 times that of ethanol. The other outstanding edge is that butanol yields $25 \%$ more Btu's (energy) per bushel corn, plus there is a hydrogen credit from the fermentation by C. tyrobutyricum of $17-18 \%$ more Btu's than ethanol enjoys. Continuous operations yield another benefit in that clean up everyday is eliminated which is a labor overhead. Given the same material handling, distillation equipment and DDG drying facilities all are basically the same except for the fermentation being anaerobic and continuous. Capital equipment for a corn-butanol biorefinery will run $15 \%$ more than an equivalent ethanol facility. The cost of production is however since the process is continuous and was found to be $\$ 0.90-\$ 1.10$ per gallon. 


\section{Bibliography}

1. Bahl, H., W. Andersch, K. Braun, and G. Gottschalk (1982), Effect of pH and butyrate concentration on the production of acetone and butanol by Clostridium acetobutylicum grown in continuous culture. European J. Appl. Microbiol. Biotechnol. 14: 17-20.

2. Barton, W. E. and A. J. Daugulis (1992), Evaluation of solvents for extractive butanol fermentation with Clostridium acetobutylicum and the use of poly (propylene glucol) 1200 . Appl. Microbiol. Biotechnol. 36: 632-639.

3. Bowles, L. K. and W. L. Ellefson (1985), Effects of butanol on Clostridium acetobutylicum. Appl. Environ. Microbiol. Nov: 1165-1170.

4. Chauvatcharin S; Siripatana C; Seki T; Takagi M; Yoshida T (1998). Metabolism analysis and on-line physiological state diagnosis of acetone-butanol fermentation, Biotechnol. Bioeng., 58, 561-571.

5. Chemical Marketing Reporter (1993), November 15, 244(12), pg 38.

6. Claassen PAM; van Lier JB; Contreras AML; van Niel EWJ; Sijtsma L; Stams AJM; deVries SS; Weusthuis RA (1999). Utilisation of biomass for the supply of energy carriers, Appl. Microbiol. Biotechnol., 52, 741-755.

7. Davison, B. H. and J. E. Thompson (1993), Continuous direct solvent extraction of butanol in a fermenting fluidized-bed bioreactor with immobilized Clostridium acetobutylicum. Appl. Biochem. Biotechnol. 39-40: 415-426.

8. Desai, R. and Papoutsakis, ET (1999). Antisense RNA strategies for the metabolic engineering of Clostridium acetobutylicum, Appl. Environ. Microbiol., in press.

9. Durre, P. (1998), New insights and novel developments in Clostridial acetone/butanol/isopropanol fermentation. Appl. Microbiol. Biotechnol. 49: 639-648.

10. Evans, P. J. and H. Y. Wang (1990) Effects of extractive fermentation on butyric acid production by Clostridium acetobutylicum. Appl. Microbiol. Biotechnol. 32: 393-397.

11. Favre, E. and Q. T. Nguyen (1996), Extraction of 1-butanol from aqueous solution by pervaporation. J. Chem. Tech. Biotechnol. 65: 221-228.

12. Ferras, E., M. Minier, and G. Goma (1986), Acetonobutylic fermentation: improvement of performances by coupling continuous fermentation and ultrafiltration. Biotechnol. Bioeng. 28: 523-533.

13. Fond, O., G. Matta-Ammouri, H. Petitdemange, and J. M. Engasser (1985), The role of acids on the production of acetone and butanol by Clostridium acetobutylicum. Appl. Microbiol. biotechnol. 22: 195-200.

14. Geng, Q., and C.-H. Park (1993), Controlled-pH Batch Butanol-Acetone Fermentation by Low Acid Producing Clostridium acetobutylicum B18, Biotechnology Letters, Vol. 15, No. 4, pp. 421-426,

15. Geng, Q. and C.-H. Park (1994), Pervaporative butanol fermentation by Clostridium acetobutylicum B18. Biotechnol. Bioeng. 43: 978-986.

16. Gottschalk, J. C. and J. G. Morris (1981), The induction of acetone and butanol production in cultures Clostridium acetobutylicum by elevated concentrations of acetate and butyrate. FEMS Microb. Letters 12: 385-389.

17. Gottwald, M. and G. Gottschalk (1985), The internal $\mathrm{pH}$ of Clostridium acetobutylicum and its effect on the shift from acid to solvent formation. Arch. Microbiol. 143: 42-46.

18. Green EM and Bennett GN (1998). Genetic manipulation of acid and solvent formation in Clostridium acetobutylicum ATCC 824, Biotechnol. Bioeng., 58, 215-221. 
19. Groot, W. J., M. C. H. den Reyer, R. G. J. M. van der Lans, and K. C. A. M. Luyben (1991), Integration of pervaporation and continuous butanol fermentation with immobilized cells II: mathematical modeling and simulations. Chem. Eng. J. 46: B11-B19.

20. Groot, W. J., H. S. Soejak, P. B. Donck, R. G. J. M. Van der Lans, K. C. A. M. Luyben, and J. M. K. Timmer (1990), Butanol recovery from fermentation by liquid-liquid extraction and membrane solvent extraction. Bioprocess Eng. 5(5): 203-216.

21. Groot, W. J., M. C. H. den Reyer, T. B. de la Faille, R. G. J. M. van der Lans, and K. C. A. M. Luyben (1991), Integration of pervaporation and continuous butanol fermentation with immobilized cells I: experimental results. Chem. Eng. J. 46: B1-B10.

22. Holt, R. A., G. M. Stephens, and J. G. Morris (1984), Product of solvents by Clostridium acetobutylicum cultures maintained at neutral pH. Appl. Environ. Microbiol. Dec: 11661170.

23. Huang, Y., S. T. Yang (1998), Acetate production from whey lactose using co-immobilized cells of homolactic and homoacetic bacteria in a fibrous-bed bioreactor. Biotechnol. Bioeng. 60(4): 498-507.

24. Huang, Y. L., K. Mann, J. Novak, and S. T. Yang (1998), Acetic acid production from fructose by Clostridium formiaceticum immobilized in a fibrous-bed bioreactor. Biotechnol. Prog. 14(5): 800-806.

25. Jain, Mahendra K., Daniel Beacom, Rathin Datta, US Patent 5,192,673 Mutant strain of Clostridium acetobutylicum and process for making butanol.

26. Jeon, Y. J. and Y. Y. Lee (1987), Membrane-assisted extractive butanol fermentation. Ann. N. Y. Acad. Sci. 506 (Biochem. Eng. 5): 536-542.

27. Jeon, Y. J. and Y. Y. Lee (1989), In situ product separation in butanol fermentation by membrane-assisted extraction. Enzyme Microb. Technol. 11(9): 575-582.

28. Jin, Z. and S. T. Yang (1998), Extractive fermentation for enhanced propionic acid production from lactose by Propionibacterium acidipropionici. Biotechnol. Prog. 14(3): 457-465.

29. Larrayoz, M. A. and L. Puigianer (1987), Study of butanol extraction through pervaporation in acetobutylic fermentation. Biotechnol. Bioeng. 30(5): 692-696.

30. Maddox, I. S. (1989), The acetone-butanol-ethanol fermentation: recent progress in technology. Biotechnol. Genet. Eng. Rev. 7: 189-220.

31. Maddox, I. S., N. Qureshi, K. Roberts-Thomson (1995), Production of acetone-butanolethanol from concentrated substrates using Clostridium acetobutylicum in an integrated fermentation-product removal process. Process Biochem. 30(3): 209-215.

32. Marchal. R., M. Ropars, J. Pourquie, F. Fayolle, and J. P. Vandecasteele (1992), Largescale enzymatic hydrolysis of agricultural lignocellulosic biomass. Part 2: conversion into acetone-butanol. Bioresource Technol. 42: 205-217.

33. Martin, J. R., H. Petitdemange, J. Ballongue and R. Gay (1983), Effects of acetic and butyric acids on solvents production by Clostridium acetobutylicum. Biotechnol. Letters 5(2): 89-94.

34. Meyer, C. L., and E. T. Papoutsakis (1989), Continuous and biomass recycle fermentation of Clostridium acetobutylicum, Part 1: ATP supply and demand determines product selectivity, Bioprocess Engineering, Vol. 4, pp. 1-10.

35. Meyer, C. L., and E. T. Papoutsakis (1989), Continuous and biomass recycle fermentation of Clostridium acetobutylicum, Part 2: Novel patterns in energetics and product-formation kinetics, Bioprocess Engineering, Vol. 4, pp. 49 - 55. 
36. Michel-Savin, D., R. Marchal, and J. P. Vandecasteele (1990), Butyric fermentation: metabolic behaviour and productin performance of Clostridium tyrobutyricum in a continuous culture with cell recycle.

37. Mollah, A. H. and D. C. Stuckey (1993), Maximizing the production of acetone-butanol in an alginate bead fluidized bed reactor using Clostridium acetobutylicum. J. Chem. Tech. Biotechnol. 56: 83-89.

38. Monot, F., J. Engasser, and H. Petitdemange (1984), Influence of $\mathrm{pH}$ and undissociated butyric acid on the production of acetone and butanol in batch cultures of Clostridium acetobutylicum. Appl. Microbiol. Biotechnol. 19:422-426.

39. Mulchandani, A. and B. Volesky (1994), Production of acetone-butanol-ethanol by Clostridium acetobutylicum using a spin filter perfusion bioreactor. J. Biotechnol. 34:51-60.

40. Nair R, Green E, Bennett GN, and Papoutsakis ET (1999). Regulation of the sol locus genes for butanol and acetone production in Clostridium acetobutylicum ATCC 824 by a putative transcription repressor, J. Bacteriol., 181, 319-330.

41. Ohno, T., T. Masawaki, M. Taya, and S. Tone (1991), Extractive butanol fermentation combined with membrane separation. Proc. Symp. Solvent Extr. 265-272.

42. Park, C.-H., M. R. Okos, and P. C. Wankat (1989), Acetone-butanol-ethanol (ABE) fermentation in an immobilized cell trickle bed reactor. Biotechnol. Bioeng. 34: 18-29.

43. Park, C.-H., M. R. Okos, and P. C. Wankat (1990), Characterization of an immobilized cell, trickle bed reactor during long term butanol (ABE) fermentation. Biotechnol. Bioeng. 36: 207-217.

44. Peguin, S, G. Goma, P. Delorme, P. Soucaille (1994), Metabolic flexibility of Clostridium acetobutylicum in response to methyl vilogen addition, Applied Microbiology Biotechnology, 42, 611-616.

45. Qureshi N; Blaschek HP (1999). Production of acetone butanol ethanol (ABE) by a hyperproducing mutant strain of Clostridium beijierinckii BA101 and recovery by pervaporation, Biotechnol. Prog., 15, 594-602.

46. Qureshi, N. and I. S. Maddox (1995), Continuous production of acetone-butanol-ethanol using immobilized cells of Clostridium acetobutylicum and integration with product removal by liquid-liquid extraction. 80(2): 185-189.

47. Shi, Z., K. Shimizu, S. Lijima, T. Morisue, and T. Kobayashi (1990), Theoretical development and performance evaluation for extractive fermentation using multiple extractants. Biotechnol. Bioeng. 36: 520-529.

48. Silva, E. M. and S. T. Yang (1995), Continuous production of lactic acid from acid whey by Lactobacillus helveticus in a fibrous-bed bioreactor. J. Biotechnol. 41: 59-70.

49. Somrutai, W., M. Takagi, and T. Yoshida (1996), Acetone-butanol fermentation by Clostridium aurantibutyricum ATCC 17777 from a model medium for palm oil mill effluent. J. Fermentation. Bioeng. 81(6): 543-547.

50. Soni, B. K. and M. K. Jain (1997), Comparison of mutant and parent strains of Clostridium acetobutylicum: butyrate uptake at different temperatures. Bioprocess Eng. 17(5): 261-267.

51. Soni, B. K. and M. K. Jain (1997), Influence of $\mathrm{pH}$ on butyrate uptake and solvent fermentation by a mutant strain of Clostridium acetobutylicum. Bioprocess Eng. 17(6): 329334.

52. Soni, B. K., P. Soucaille, and G. Goma (1987), Continuous acetone-butanol fermentation: a global approach for the improvement in the solvent productivity in synthetic medium. Appl. Microbiol. Biotechnol. 25: 317-321. 
53. Soni, B. K., P. Soucaille, and G. Goma (1987), Continuous acetone-butanol fermentation: influence of vitamins on the metabolic activity of Clostridium acetobutylicum. Appl. Microbiol. Biotechnol. 27: 1-5.

54. Terracciano, J. S. and E. R. Kashket (1986). Intracellular conditions required for initiation of solvent production by Clostridium acetobutylicum. Appl. Environ. Microbiol. July: 8691.

55. Yang, S. T., H. Zhu, Y. Li, and G. Hong (1994), Continuous propionate production from whey permeate using a novel fibrous bed bioreactor. Biotechnol. Bioen. 43: 1124-1130.

56. Yang, S. T., Y. Huang, and G. Hong (1995), A novel recycle batch immobilized cell bioreactor for propionate production from whey lactose. Biotechnol. Bioeng. 43: 379-386.

57. Yang, X., G.-J. Tsai, and G. T. Tsao (1994), Enhancement of in situ adsorption on the acetone-butanol fermentation by Clostridium acetobutylicum. Sep. Technol. 4: 81-92.

58. Yang, X. and G. T. Tsao (1994), Mathematical modeling of inhibition kinetics in acetonebutanol fermentation by Clostridium acetobutylicum. Biotechnol. Prog. 10: 532-538.

59. Yang, X. and G. T. Tsao (1995), Enhanced acetone-butanol fermentation using repeated fed-batch operation coupled with cell recycle by membrane and simultaneous removal of inhibitory products by adsorption. Biotechnol. Bioeng. 47: 444-450.

60. Young, M., N. P. Minton, and W. L. Staudenbauer (1989), Recent advantages in the genetics of the clostridia. FEMS Microbiol. Rev. 63: 301-326.

\section{Additional sources of references:}

1. http://gaia.bae.umn.edu/annrpt/1994/research/bio3.html

2. http://www.life.uiuc.edu/biotech/people/Blaschek.html

3. http://www.ilcorn.org/reports/97011102mbi.html 
Appendix A

Decantation Recovery Modality

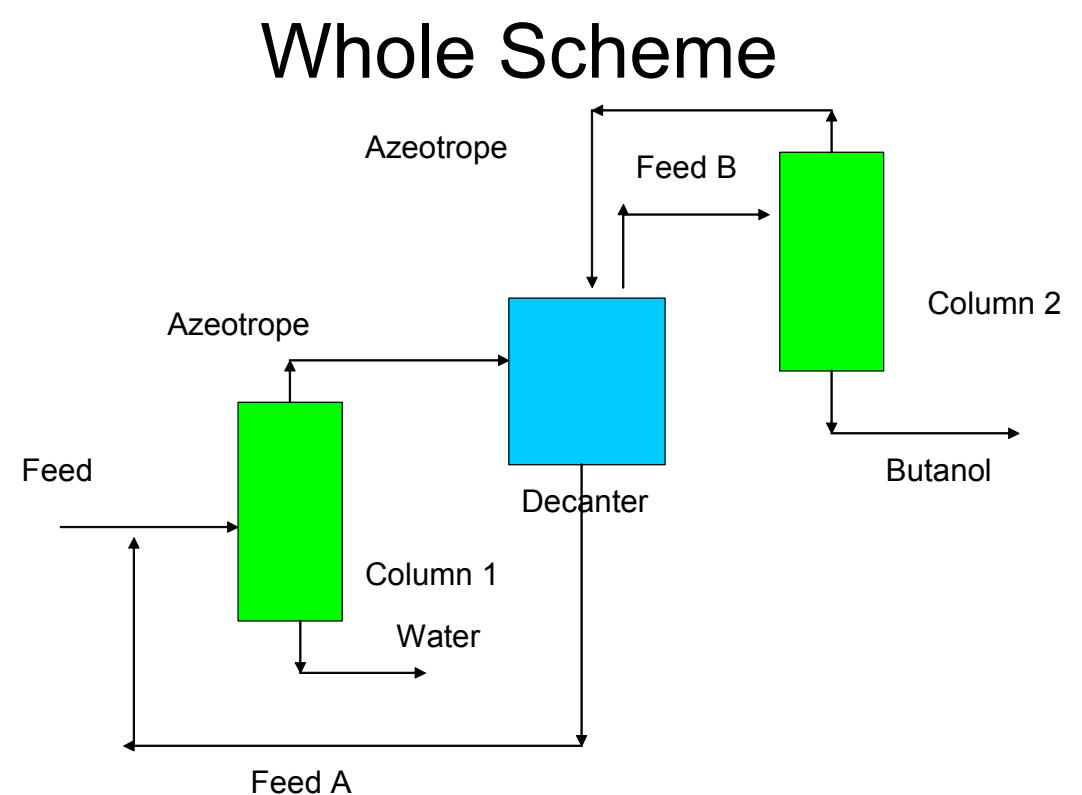

\section{Distillation in Column 1}

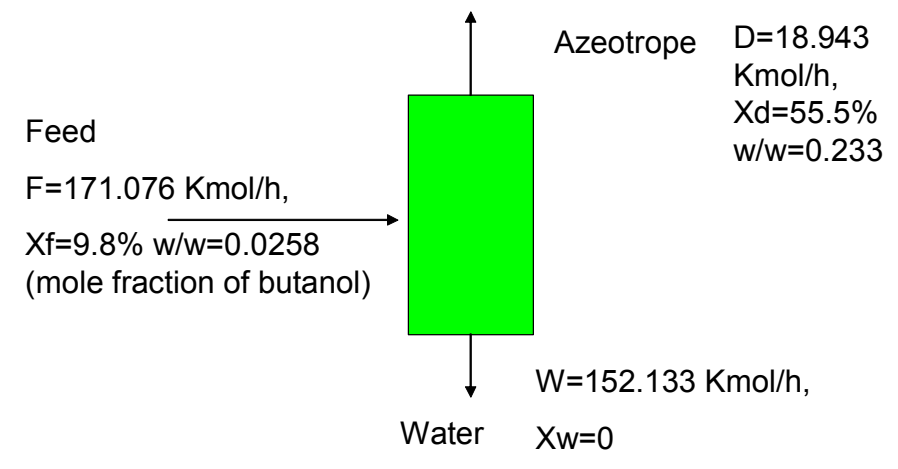


- If the reflux ratio is low, then we need more stages in column 1, namely the cost of reactor is high, but low energy consumption in reboiler and low duty for condenser. If the reflux ratio is high, we need less stages, however we will have high consumption of energy, high duty for condenser.

- Suppose we operate the distillation column at $1 \mathrm{~atm}$, total condenser, the temperatures of the mixture in the feed and distillate can be obtained from property chart $(T-X)$. The property chart can be obtained by running aspen plus software.

- Location of feed tray in column 1

Obtain Y-X chart by running aspen plus software, set a reflux ratio, then draw the two operation lines using equations, from the figure, we can see that feed stream should be above stage 2 .

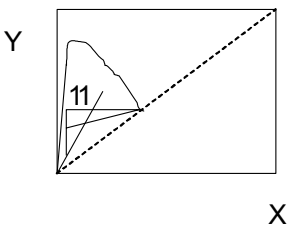

- we set the reflux ratio to be 0.05 , set the stages of the column to be 25 , then by running Aspen Plus software, we obtain pure water in the bottom of column and azeotrope on the top by running the simulation. The reboiler duty is 893482 $\mathrm{Btu} / \mathrm{hr}$, the condenser duty is -797703 $\mathrm{Btu} / \mathrm{hr}$. 


\section{Distillation in column 2}

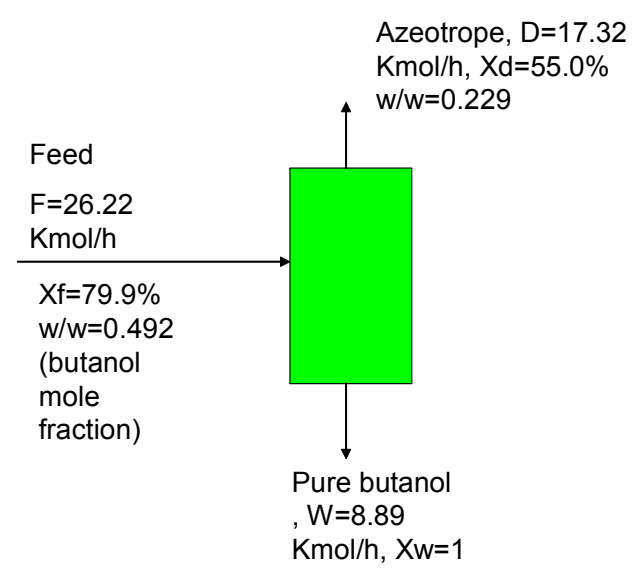

- Suppose we operate the distillation column at $1 \mathrm{~atm}$, total condenser, the temperatures of the mixture in the feed can be obtained from property chart (T-X). The property chart can be obtained by running aspen plus software. The boiling point of butanol is 117 degree $C$. The boiling point of azeotrope is 93 degree $\mathrm{C}$.

-Location of feed tray in column 2

Obtain Y-X chart by running aspen plus software, set a reflux ratio, then draw the two operation lines using equations, from the figure, we can see that feed stream should be above stage 2. $r$

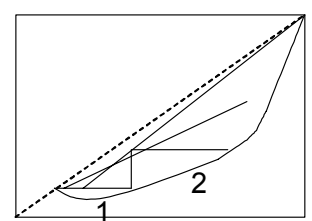


- we set the reflux ratio to be 1.5 , set the stages of the column to be 16 , then by running Aspen Plus software, we obtain pure butanol in the bottom of column and azeotrope on the top by running the simulation. The reboiler duty is 807135 $\mathrm{Btu} / \mathrm{hr}$, the condenser duty is -783024 Btu/hr.

\section{Stripping and decantation and distillation recovery}

For the first distillation tower:

For $\mathrm{X}_{\mathrm{F}}=0.0258 \quad \mathrm{Xw}=0 \quad \mathrm{X}_{\mathrm{D}}=0.233$

$\mathrm{F}=171.076 \mathrm{Kmol} / \mathrm{h} \quad \mathrm{D}=18.943 \mathrm{Kmol} / \mathrm{h} ， \mathrm{~W}=152.133 \mathrm{Kmol} / \mathrm{h}$

Run the aspen plus software,

Reflux ratio is 0.05 , Need 25 stages, feed stage is above stage 2 .

Condenser duty is $-797703 \mathrm{Btu} / \mathrm{hr}$, reboiler duty is $893482 \mathrm{Btu} / \mathrm{hr}$.

For the second distillation tower:

For $\mathrm{X}_{\mathrm{F}}=0.492, \mathrm{XW}_{\mathrm{W}}=1 \quad \mathrm{X}_{\mathrm{D}}=0.229$

$\mathrm{F}=11.799 \mathrm{Kmol} / \mathrm{h} \quad \mathrm{D}=7.815 \mathrm{Kmol} / \mathrm{h} \quad \mathrm{W}=3.984 \mathrm{Kmol} / \mathrm{h}$

Run the aspen plus software,

Reflux ratio is 1.5 , Need 16 stages, feed stage is above stage 2 .

Condenser duty is $-783024.67 \mathrm{Btu} / \mathrm{hr}$, reboiler duty is $807135.984 \mathrm{Btu} / \mathrm{hr}$.

\section{Design:}

The first distillation tower:

$\mathrm{F}=171.076 \mathrm{Kmol} / \mathrm{h}=15 \mathrm{gal} / \mathrm{min} \mathrm{D}=2.93 \mathrm{gal} / \mathrm{min}$

$\mathrm{L}=\mathrm{RD}+\mathrm{F}=0.05 * \mathrm{D}+15=15.15 \mathrm{gal} / \mathrm{min}$

For $250 \mathrm{gal} / \mathrm{week}=0.025 \mathrm{gal} / \mathrm{min}$.

Pure butanol is $0.76 \mathrm{gal} / \mathrm{min}$ for $\mathrm{F}=15 \mathrm{gal} / \mathrm{min}$. 
$0.76 / 0.025=30$ times $\quad 15.15 / 30=0.5 \mathrm{gal} / \mathrm{min}$

Choose reverse flow, diameter of the first distillation tower is 3 feet.

Height of distillation tower:

$\mathrm{H}=3.28 *(0.61 *$ stages/efficiency +4.27$)=69.6$ feet

Cost of distillation tower $=4.34 *\left(762 * \operatorname{Diameter}^{*}(\mathrm{H} / 12.2)^{0.68}\right)=32420$

Cost of trays $=60.5^{*}($ stages $/$ efficiency $)$ Diameter ${ }^{1.9}=60.5^{*}(25 / 0.9) * 3^{1.9}=9160.7$

Cost of steam is $\$ 6$ / million Btu.

So the steam cost is $\$ 0.34 / \mathrm{hr}$.

$\mathrm{F}=11.799 \mathrm{Kmol} / \mathrm{h}=2.813 \mathrm{gal} / \mathrm{min} \quad \mathrm{D}=1.19 \mathrm{gal} / \mathrm{min}$

$\mathrm{L}=\mathrm{RD}+\mathrm{F}=1.5 * 1.19+2.813=4.598 \mathrm{gal} / \mathrm{min}$

For 250 gallon per week,

$4.598 / 30=0.15 \mathrm{gal} / \mathrm{min}$

Choose reverse flow, diameter of the second distillation tower is 3 feet.

Height of distillation tower

$\mathrm{H}=3.28 *(0.61 *$ stages/efficiency +4.27$)=49.6$ feet

Cost of distillation tower $=4.34 *\left(762 *\right.$ Diameter* $\left.(\mathrm{H} / 12.2)^{0.68}\right)=25749.5$

Cost of trays $=60.5^{*}($ stages $/$ efficiency $)$ Diameter ${ }^{1.9}=9160.7$

Total cost of equipment $=32420+9160.7+25749.5+9160.7=76491$

For $1200 \mathrm{gal} / \mathrm{week}=0.12 \mathrm{gal} / \mathrm{min}$.

Pure butanol is $0.76 \mathrm{gal} / \mathrm{min}$ for $\mathrm{F}=15 \mathrm{gal} / \mathrm{min}$.

$0.76 / 0.12=6.3$ times $\quad 15.15 / 6.3=2.4 \mathrm{gal} / \mathrm{min}$

Choose reverse flow, diameter of the first distillation tower is 3 feet. 
Height of distillation tower:

$\mathrm{H}=3.28 *(0.61 *$ stages/efficiency +4.27$)=69.6$ feet

Cost of distillation tower $=4.34 *\left(762 *\right.$ Diameter $\left.*(\mathrm{H} / 12.2)^{0.68}\right)=32420$

Cost of trays $=60.5^{*}($ stages $/$ efficiency $)$ Diameter ${ }^{1.9}=60.5 *(25 / 0.9) * 3^{1.9}=9160.7$

Cost of steam is $\$ 6$ / million Btu.

So the steam cost is $\$ 1.6 / \mathrm{hr}$.

$\mathrm{F}=11.799 \mathrm{Kmol} / \mathrm{h}=2.813 \mathrm{gal} / \mathrm{min} \quad \mathrm{D}=1.19 \mathrm{gal} / \mathrm{min}$

$\mathrm{L}=\mathrm{RD}+\mathrm{F}=1.5^{*} 1.19+2.813=4.598 \mathrm{gal} / \mathrm{min}$

For 1200 gallon per week,

$4.598 / 30=0.15 \mathrm{gal} / \mathrm{min}$

Choose reverse flow, diameter of the second distillation tower is 3 feet.

Height of distillation tower

$\mathrm{H}=3.28 *(0.61 *$ stages/efficiency +4.27$)=49.6$ feet

Cost of distillation tower $=4.34 *\left(762 *\right.$ Diameter* $\left.(\mathrm{H} / 12.2)^{0.68}\right)=25749.5$

Cost of trays $=60.5^{*}($ stages$/$ efficiency $)$ Diameter $^{1.9}=9160.7$

Total cost of equipment $=32420+9160.7+25749.5+9160.7=76491$

For $100000 \mathrm{gal} / \mathrm{week}=9.9 \mathrm{gal} / \mathrm{min}$.

Pure butanol is $0.76 \mathrm{gal} / \mathrm{min}$ for $\mathrm{F}=15 \mathrm{gal} / \mathrm{min}$.

$9.9 / 0.76=13$ times $\quad 15.15 * 13=195 \mathrm{gal} / \mathrm{min}$

Choose cross flow, diameter of the first distillation tower is 3 feet.

Height of distillation tower:

$\mathrm{H}=3.28 *(0.61 *$ stages/efficiency +4.27$)=69.6$ feet 
Cost of distillation tower $=4.34 *\left(762 * \operatorname{Diameter}^{*}(\mathrm{H} / 12.2)^{0.68}\right)=32420$

Cost of trays $=60.5^{*}($ stages $/$ efficiency $)$ Diameter ${ }^{1.9}=60.5 *(25 / 0.9) * 3^{1.9}=9160.7$

Cost of steam is $\$ 6$ / million Btu.

So the steam cost is $\$ 13 / \mathrm{hr}$.

$\mathrm{F}=11.799 \mathrm{Kmol} / \mathrm{h}=2.813 \mathrm{gal} / \mathrm{min} \quad \mathrm{D}=1.19 \mathrm{gal} / \mathrm{min}$

$\mathrm{L}=\mathrm{RD}+\mathrm{F}=1.5 * 1.19+2.813=4.598 \mathrm{gal} / \mathrm{min}$

For 1200 gallon per week,

$4.598 * 13=60 \mathrm{gal} / \mathrm{min}$

Choose cross flow, diameter of the second distillation tower is 3 feet.

Height of distillation tower

$\mathrm{H}=3.28 *(0.61 *$ stages/efficiency +4.27$)=49.6$ feet

Cost of distillation tower $=4.34 *\left(762 *\right.$ Diameter $\left.*(H / 12.2)^{0.68}\right)=25749.5$

Cost of trays $=60.5 *($ stages $/$ efficiency $)$ Diameter ${ }^{1.9}=9160.7$

Total cost of equipment $=32420+9160.7+25749.5+9160.7=76491$

\$ 76,491 for thousand gallons butanol per week

Equipment and hardware total $\$ 1,175,920$.

Additional items would be Installation and startup $(\$ 35,000)$ and Labor $(\$ 258,000)$.

The total is just over $\$ 1.4$ million as follows:

Equipment \& Hardware - \$1,175,920

35,000

258,000

$\$ 1,468,920$ 


\section{Pilot Plant Equipment \& Hardware}

\section{The total system would comprise:}

1) Receiving Whey Permeate concentrate into the 3000 gallon Whey concentrate tank and controlling storage temperature.

2) Supplying Whey Concentrate to the Whey Sterilizer (UHT) via a two stream blending system to reduce to $4.5 \%$ Lactose for sterilization.

3) The UHT is fully automated and includes a dedicated CIP capability to clean the plate HXR's, the flash chamber, and all piping and valves from the Whey Conc tank to the Sterile Whey tank after each run.

4) A Bioreactor hardware skid to include all pumps, valves and filters to support the two stage (two vessel) process, from the Sterile Whey tank to the broth discharge to the stripper, and SIP and CIP this equipment via completion of field piping connections from skid to skid and tank to tank.
Sterile whey truck loose quick connects and cleaning station

Dual Stream blending system

Whey Sterilizer Skid

Butylizer Skid - Pumps, Valves and Filters for 250-1250/week : 2 Small BR's (included w/skid)

A DIRCR Control Panel with remote HMI (one), PLC, VFD's, starters for fixed speed process pumps, and all sensors to control CIP, UHT, and two stage Controls (CIP, UHT \& Butylizer)- PLC Butylizer process, with software based on current understanding to be confirmed by a Function Spec by EEI when required.

with software, Sensors, VFD's, etc

6) A CIP Skid capable of CIP cleaning the tanker, Whey Conc Tank, Sterile Whey Tank, and all field installed connecting piping, including CIP Return Pumps, spray devices, U-Bend transfer panels and chemical feed equipment. This CIP unit will be fully automated and will be controlled by the PLC in (5) above).

7) Expansion from $250 \mathrm{gpw}$ to 1,250 reactors

80,000

80,000

Total parts and pieces plus freight to Blacklick, $\mathrm{OH}$

\section{Recovery:}

8) Liquid - Liquid extraction for AmmPro scaling

9) Countercurrent stripping towers butanol

10) Distillation column

\begin{tabular}{rr} 
Extractors & 150,000 \\
Dryers - Distillation & 165,000 \\
Infrastructure & 15,120 \\
\hline & $\mathbf{3 3 0 , 1 2 0}$
\end{tabular}

\section{Other Auxilliary Items}

1) A NEW 2000 gallon Sterile Whey, with above loose components on a skid will involve an adder of :

2) To replace the $3^{\prime} x 7^{\prime}$ tanks for scale up with 5 'x $12^{\prime}$ tanks using the same valves and pumps on the Butylizer skid with two tanks of 5'x12' size, with distribution plate, upriser, sprays and pod outlet will involve and adder of . .

4) Estimated cost of field st st piping, installed is approximately . . .

5) A 3000 gallon whey tank, horizontal, vertical agiator, 2"outlet, $94 \mathrm{sq} \mathrm{ft}$ for chilled water, 98" dia., used price is currently 10,600 . Similar design but new is :

6) To provide a more detailed process flow diagram of the overall process, and GA drawings of the equipment modules CIP, Conc whey, HTST, Sterile whey and Butylizer, for fabrication purposes (and purchase of vessels) include an adder

\section{EEI will need to provide:}

1) $50 \mathrm{Hp}$ Steam Generator for CIP, UHT and Butylizer steam, at 20-25 Psi. 75,000

2) A small chilled water tank and compressor for the Whey Conc tank cold wall surface. 30,000

3) An air compressor.

4) A water tower, pump and piping for the tower water coolers on the UHT.

5) Modifications and completion of the building and building utilities as required for proper installation and op€ 150,000

6) All downstream purification equipment and support auxiliaries, and utilities and controls for same. 125,000 


\title{
Appendix B
}

\section{BUSINESS PLAN}

\section{ChemLac Corporation}

A subsidiary of Environmental Energy, Inc.

2005

\section{CONFIDENTIAL MATERIAL DISCLOSED \\ PLEASE DO NOT CIRCULATE}

\author{
1253 N. Waggoner Road \\ P.O. Box 15 \\ Columbus, Ohio 43004 \\ Telephone: (614) 864-5650 \\ Fax: (614) 864-0120 \\ http://www.butanol.com \\ Inquiries and requests for information should be directed to one of the following: \\ David Ramey dramey@butanol.com
}

(c) 2005 ChemLac Corporation

All documents, information or other materials which constitute "trade secrets" within the meaning of the Ohio Revised Code relating to the accompanying materials may not be disclosed to any person or legal entity without prior written authorization of Environmental Energy Inc. Any unauthorized disclosure may result in civil and/or criminal liability.

This document does not, by itself, constitute an offer to buy or sell securities. An offer to buy or sell securities is only made by a prospectus and offering circular, including the accompanying documents defined in the prospectus. 


\section{EXECUTIVE SUMMARY}

ChemLac Corporation has developed plans described herein to commercialize patented technology and other intellectual property developed by its parent Environmental Energy Inc. (EEI) to produce fuels and chemicals from multiple forms of biomass, including but limited to whey, a waste from the manufacture of cheese. These plans build on a successful 15-year research \& development effort which has provided the company with a solid base of intellectual property for achieving EEl's three primary goals:

- $\quad$ To create an economical alternative to oil, particularly foreign oil, as a major source strategic chemicals and energy

- $\quad$ To provide a means of alleviating global warming

- $\quad$ To create sustainable employment, in Ohio and elsewhere

These goals are now attainable. EEl's technology can produce butanol (and other biologically derived chemicals, ethers and esters) from many forms of biomass. Butanol is an alcohol presently used as an industrial solvent. Additionally, butanol is used as a raw material in the production of many finer chemicals. All butanol supplies worldwide are currently being produced using petroleum as a feedstock.

Prior to the success of EEl's work, there was no economical means to produce butanol using common agricultural feedstocks. However, EEl's work opens the possibility to produce organic butanol not only for use as a solvent, but as a fuel to replace gasoline.

As a potential gasoline replacement, butanol has an energy yield twenty-five percent (25\%) greater than ethanol's energy yield, from the same bushel of corn, or other suitable biomass. The improved energy yield comes from three properties intrinsic to butanol and/or EEl's patented technology

- The higher energy content of butanol vs. ethanol, (four carbon vs. 2 carbon)

- EEl's technology produces a higher percentage of biomass that is converted to butanol,

- EEl's process results in the production of significant quantities of precious hydrogen.

The hydrogen "bonus" further skews the economics in favor of butanol vs. ethanol. Additionally, due to its lower vapor pressure, butanol is safer and easier to handle than ethanol. Also, butanol is much less corrosive on metal parts and can be distributed through existing pipelines. Butanol can be used as a direct one-to-one replacement for gasoline without any modifications to fuel injected automobiles as proven in the 10,000 mile demonstration run across the Nation and only minor changes to timing in a carbureted system.

The immediate next steps in EEl's commercialization plan are to build a pilot plant that will produce 250 gallons per week and then expanded to 1,250 gallons per week of product using whey as feedstock. This work will be executed by ChemLac Corporation which was created by EEI for this purpose. Subsequently ChemLac will produce butanol for sale into the commercial solvents or fuels market. Agreements with strategic partners are in the process of being developed to assist with key aspects of production, marketing and distribution of butanol. Commercial operations are expected to begin within 24 months.

In parallel with development of the butanol market, ChemLac plans to license the technology for the first of two stages of EEl's patented technology for making butanol to a major agricultural company that will build and operate a plant to produce ammonium propionate. (Confidentiality agreements prevent us from disclosing the identity of that company in this document.)

Earnings from the sales of butanol to the solvent market and royalties from the agro-foods company are expected to be sufficient to fund EEl's entry into the biomaterials and alternative fuels market, which is expected to take about 5 years. 
The pilot plant work will cost approximately $\$ 3$ million and take 1-2 years to complete, which will be funded by a $\$ 1$ million advance royalty payment from the agro-foods Company and $\$ 2$ million of equity investment capital in ChemLac. It is estimated that the $\$ 2$ million equity investment will return approximately $\$ 41$ million after 7 years when ChemLac plans an IPO. These projections are based solely on expected royalties from the agro-foods Company and earnings from the sale of butanol as a commercial solvent in the U.S. market. Excluded, because reliable estimates cannot be formulated at this time, are earnings the company should realize from international markets, from the biomaterials and fuels markets beyond butanol, and from licensing its technology to numerous potential users in many diverse industries.

Mr. David E. Ramey who is the inventor of the Company's core technology incorporated EEI in 1991. From $1991 \mathrm{EEl}$ has operated on funds (totaling approximately $\$ 1.5$ million) provided by 40 private investors, and by several federal research grants. The funds have been used to develop a portfolio of intellectual property, some of which is protected by patent and some of which is being held as trade secrets before being patented. Private funds were also used to construct a 10,500 square foot Technical Development Center in Blacklick, Ohio (east of Columbus) where laboratory and pilot scale work is conducted.

\section{INTRODUCTION}

ChemLac Corporation is a creation of Environmental Energy Inc. (EEI) which has developed patented technology to produce alternative fuel (e.g. gasoline replacement http://360.yahoo.com/dramey756 ) and chemicals from renewable biomass. Preliminary assessments suggest that EEl's technology may be used to produce fuels and chemicals with significant economic and environmental advantages as compared with petrochemical feedstocks and other alternative technologies. Beyond economic benefits, advantages that will result from commercializing EEl's technology include reduced greenhouse gas emissions and reduced dependence on foreign oil.

ChemLac was formed to be a commercial vehicle for beginning the commercialization of EEl's technology. The EEI technology commercialized by ChemLac is a two-stage fermentation process that produces carboxylic acids in the first stage and from the acid produced in the first stage produces butanol in the second stage. Each stage of ChemLac's process employs patented fermentation reactor technology that has been licensed from The Ohio State University.

Butanol is an alcohol used primarily as an industrial solvent. However, butanol has properties that make it an excellent replace for gasoline and EEl's technological breakthroughs have made the economics of producing butanol from biomass for both uses very compelling.

Sugar-rich biomass is the feedstock for the EEI process. The feedstock may be cultivated crops such as corn and switchgrass or waste products from the food industry such as whey. ChemLac's business scope employs cheese whey, a lactose-rich, difficult and expensive to dispose waste from the manufacture of cheese, to produce butanol.

Additionally, ChemLac plans to license the technology for the first stage of its process to its strategic partner, a major agricultural company, to manufacture ammonium propionate from cheese whey. This prospective strategic relationship with the agro-foods company will provide ChemLac with funds needed to complete development of the butanol production process and with a commercial-scale demonstration of the OSU-developed and -patented reactor technology to be employed in the butanol production process.

EEl's technology is based on technological improvements in the historical yield of butanol produced through fermentation. EEl's technology has been developed over a period of 15 years with funding from private investors and grants from government agencies. Total funds expended over that period of time are approximately $\$ 1.5$ million. These expenditures have yielded proprietary technology in the form a patent and certain proprietary know-how that will be retained as trade secrets. 
Through ChemLac EEl is concentrating its immediate efforts on commercializing its technology to produce butanol from cheese whey for use as an industrial solvent. This is because the profit margins in the industrial solvent market are higher than would be the case in the current fuels market, and because the fuels market requires additional development before it is ready to accept butanol as a commercial fuel.

This Business Plan is designed to solicit investor support to build two biorefineries each with the capacity to process 5 million pounds of whey per day, and producing a total of approximately 61 million pounds of butanol per year that will be sold to the industrial solvent market which currently consumes about 2.1

billion pounds of year of butanol.

\section{FINANCIAL PROJECTIONS \\ THESE PROJECTIONS ARE PROVIDED FOR INFORMATION ONLY AS TO OUR CURRENT THINKING. THEY ARE SUBJECT TO OUR FURTHER REVIEW AT REVISION}

The financial projections for ChemLac are based on building two plants that each process 5 million pounds of whey per day. The Company will operate for 7 years, after which it is assumed that an IPO will be executed to provide an exit opportunity for investors. At that time the company is restructured to accommodate the interest of investors who may want to continue their participation, strategic partners, key customers and company management.

Additionally the Company will participate in a strategic partnership with the agro-foods company Industries who will sub-license technology from the Company to produce ammonium propionate.

The agro-foods company partnership provides ChemLac with:

- An early opportunity to demonstrate the efficacy of the Company's technology is used to produce butanol

Income from sales will be employed to assist with funding of the butanol business.

\section{Plant Operations}

At full operation both plants process 5 million pounds of whey per day and produce $30,796,875$ pounds of butanol per year. Plant 1 will begin operation in 2007 (Year 2) operating at 25 percent of full capacity. Plant 2 will begin operating in 2010 (Year 5) at 25 percent of full capacity. When both plants have achieved full capacity, beginning in 2011, the total production of butanol is $61,593,750$ pounds per year ( $\sim 9$ million gallons a year). A minor fraction of the national consumption which, as noted earlier, is about 2.1 billion pounds per year.

\section{Assumptions}

The financial projections are based on the following assumptions:

- Lactose: 0.045 pounds of lactose per pound of whey

- Fermentation Yield: Pounds of butanol per pound of lactose -0.375

- Production Rates

Pounds of butanol/year per pound of why/day -6.16

- Cost to Produce Product (excluding capital cost and related items) 
Butanol - \$0.12/pound

\section{- Selling price of products}

Butanol - $\$ 0.40$ in 2005 - assumed to escalate at 4 percent/year (constant dollars)

- Tipping Fee $-\$ 0.001 /$ pound of whey (net of any residuals disposal cost)

\section{- Fixed Capital Investment}

Plant 1 - $\$ 6,000,000$

Plant 2 - $\$ 6,000,000$

\section{Investor Participation}

An equity investor(s) is being sought to contribute $\$ 2,000,000$ to cover planning and start up costs for Plant 1. This investor or investor group receive 15 percent equity ownership in ChemLac Corporation. Upon sale and or restructuring of the Company after 7 years' operation, that investor will receive an estimated payout of $\$ 41,488,632$ - or slightly more than a $20: 1$ return on his/her money.

\section{Other Assumptions}

Other key assumptions upon which these financial projections are based include:

- ChemLac is able to finance the entire $\$ 6,000,000$ required to construct Plant 1 at an interest rate of 8 percent.

- At the end of Year 7, the Company will be able to execute an IPO in which the Company will be sold for an amount equal to 10 times the earnings in Year $7(\$ 21,749,241)$.

- Prior to the IPO, the $\$ 6,000,000$ borrowed to finance Plant 2 would be repaid.

\section{Performance Summary}

During the projected 7 years of operation, ChemLac earns $\$ 65,096,475$ (after taxes and repayment of all debt.

The Company becomes profitable in 2007 (Year 2). The profit in Year 2 is $\$ 1,159,231$ after taxes.

In Year 1 the Company operates at a loss of $\$ 1,776,920$, which is covered by the $\$ 2,000,000$ infusion of equity capital.

\section{Investor Returns}

Working with these assumptions, it is projected that investor return is as follows:

The equity investor who contributes $\$ 2,000,000$ receives from earnings and proceeds of the IPO a total of $\$ 41,488,632$ which corresponds to a $66 \%$ compound annual rate of return. 


\section{Appendix C}

\section{Final Demonstration of the Efficacy of BUTANOL To Replace Gasoline Gallon for Gallon \\ Pictures are worth a thousand words}

050627 1,150 miles on Butanol - Springfield OH Emissions test. 95\% reduction in hydrocarbons

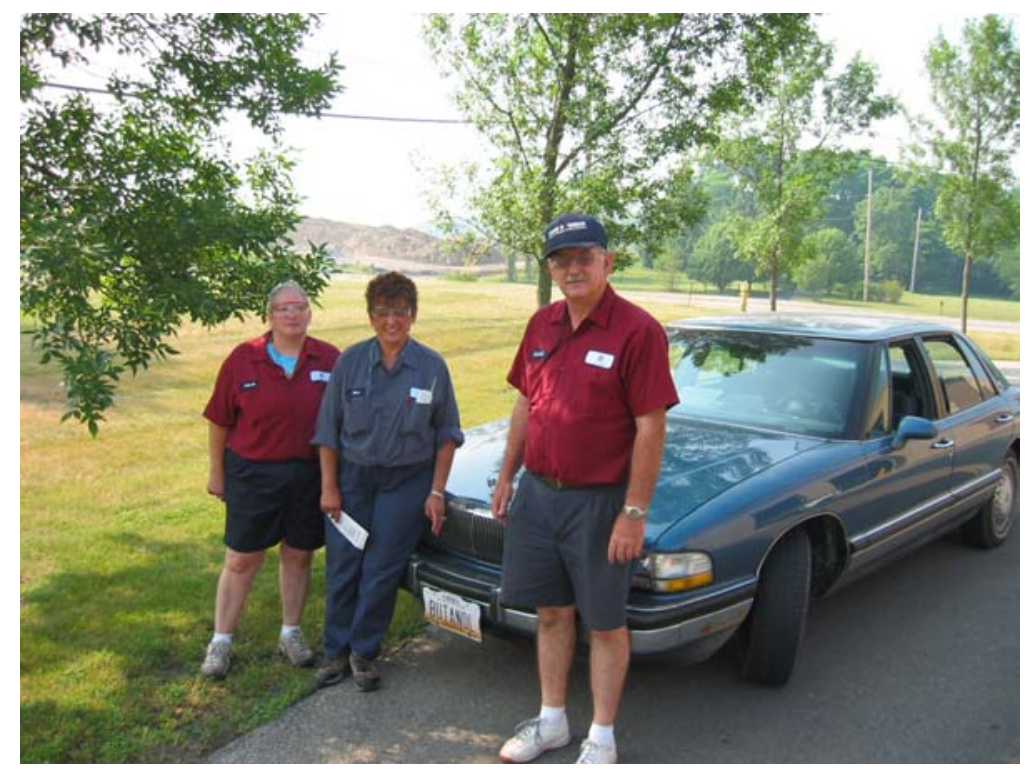

050718 2,500 miles St Louis MO Emissions Test

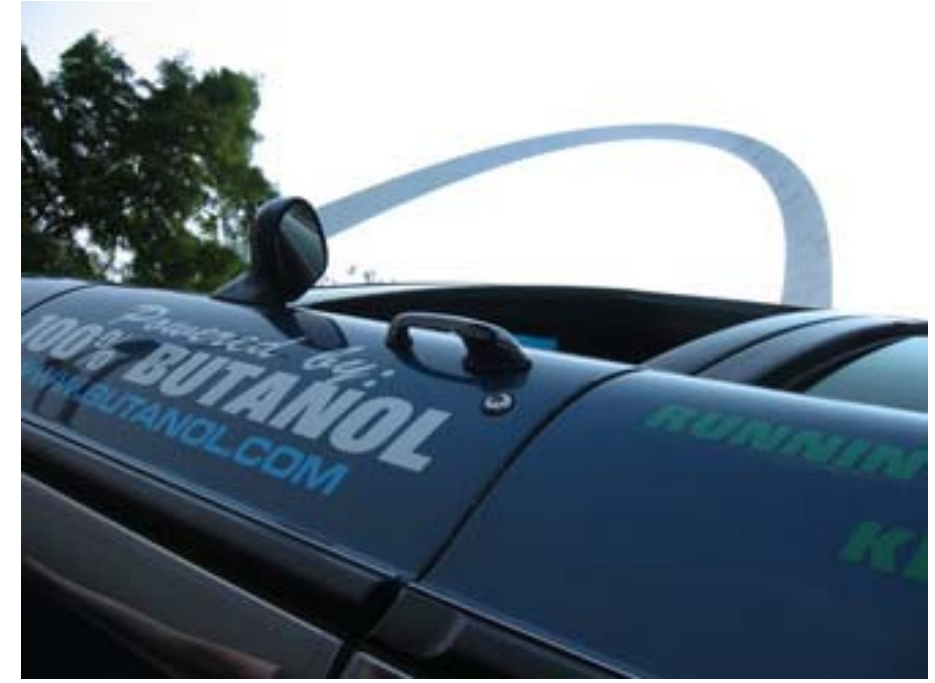

As a Demonstration Run across the Nation we took several pictures. But in these few you will see Butanol replacing gasoline mile after mile after mile. Butanol can be made from corn today simply. Just as simple as it is to change the fluid we put in our tank. Cars we do not have to modify to go down the road easily today if we had Butanol available.

Butanol's emissions were staggering low. The Referee enjoyed driving the car and smelling the gas cap. Off to San Diego 
050726 San Diego CA 5,008 miles

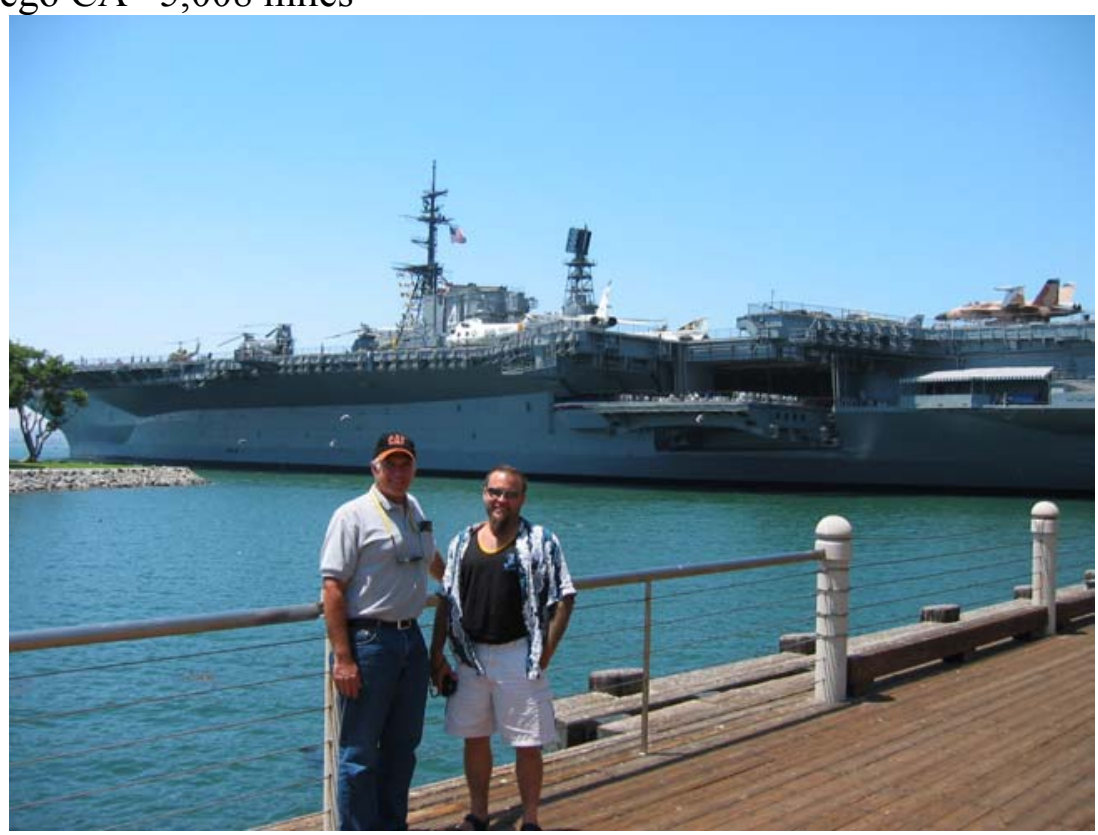

Marshal Wiseman and Jim Adkins in San Diego by the Mighty Midway

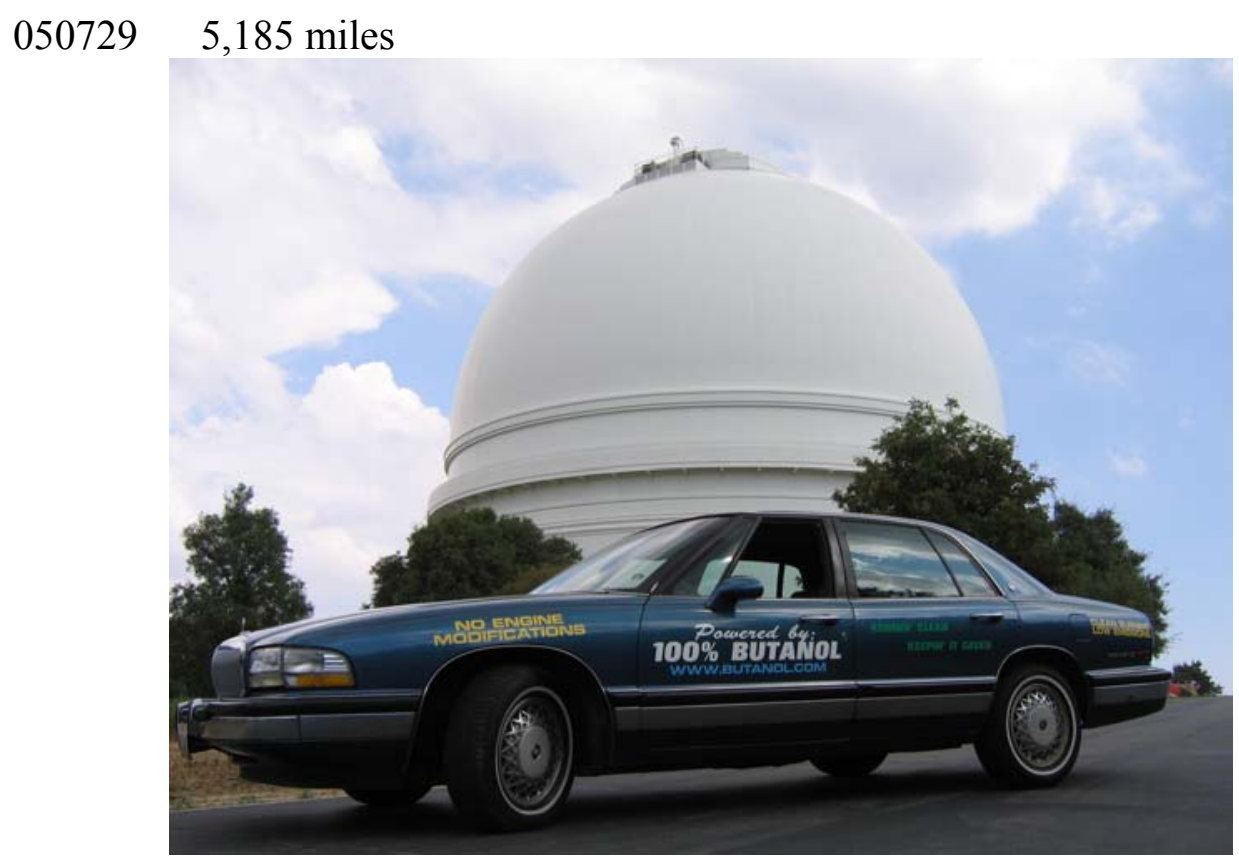

Mount Palomar was very easy to climb. 
050801 La Brea Tar Pits Los Angeles 5,500 Miles We do not have to use oil to go down the road anymore.

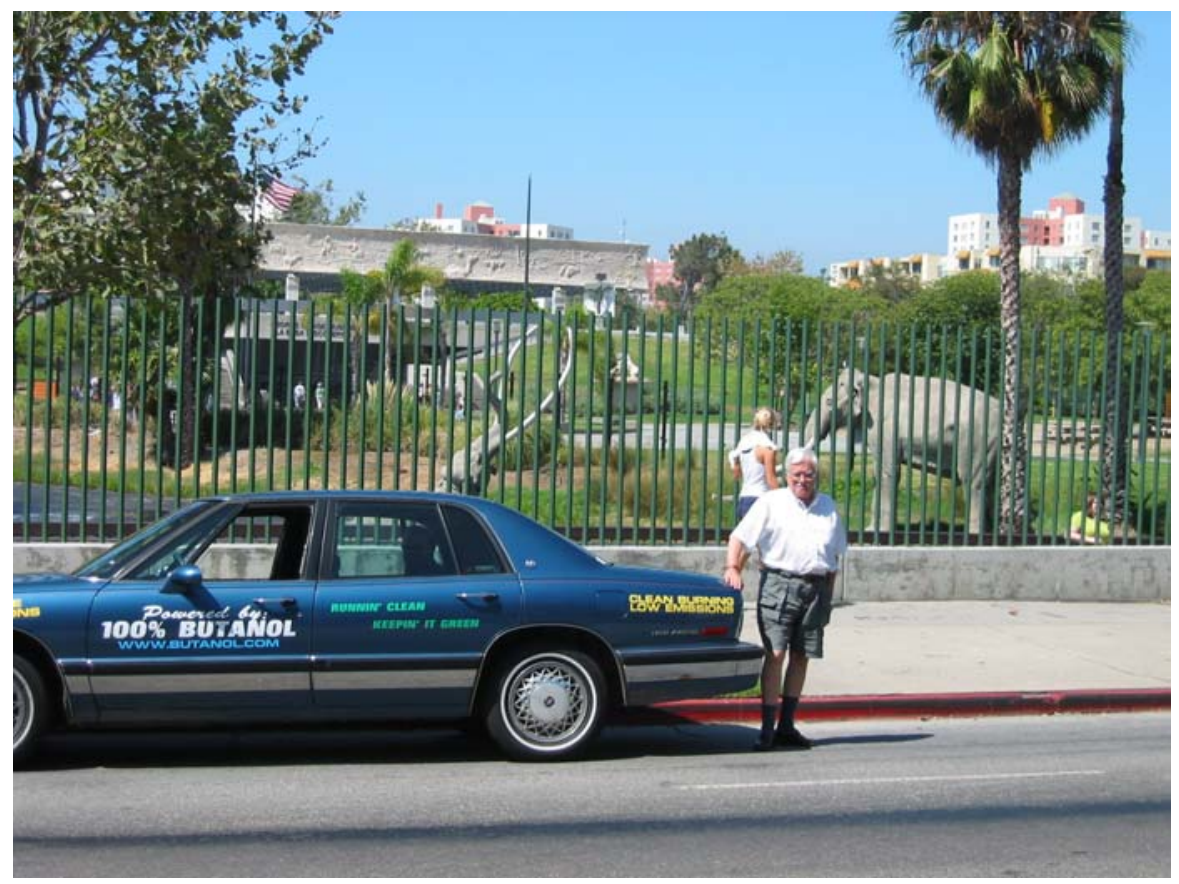

050804 The Golden Gate 6,250 miles

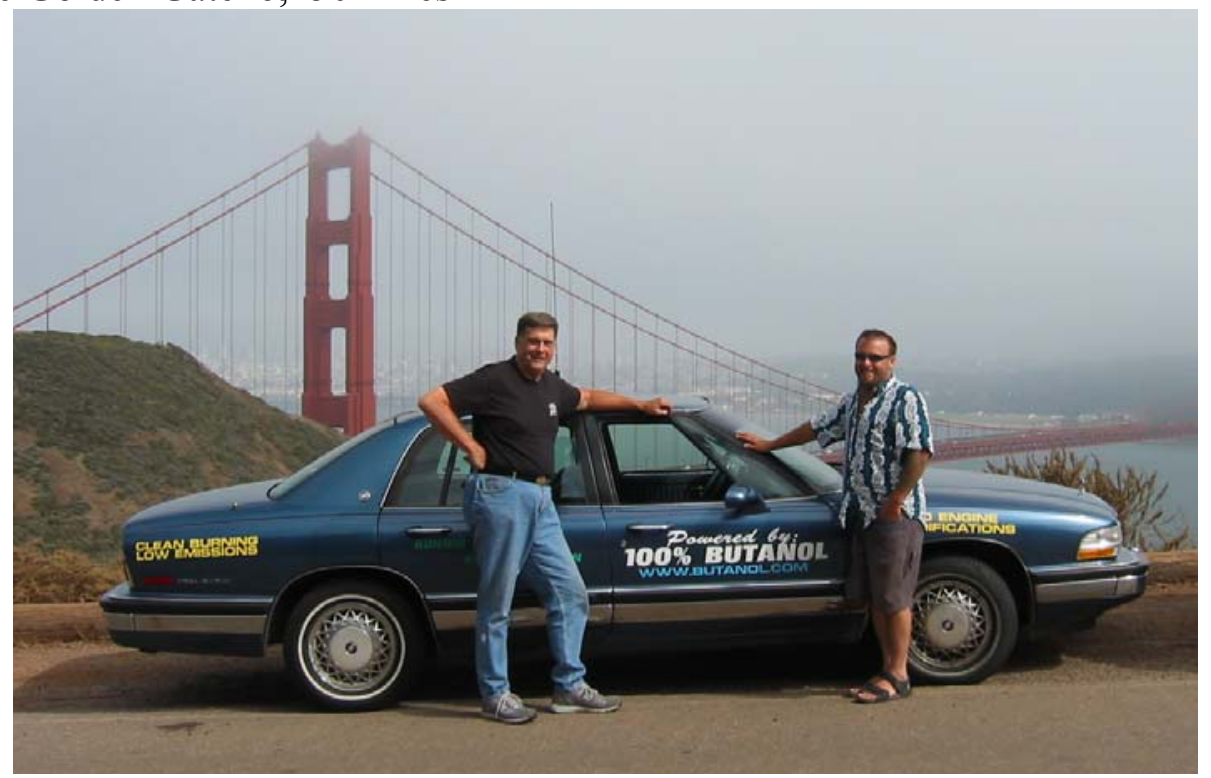

David Ramey and Jim Adkins "The Golden Gate” now off to Washington: 
National Renewable Energy Laboratory Golden Colorado: The NREL does not even have Butanol listed in their data bank. No one knows about butanol until now. Please start working with it.

$050808 \quad 7,000$ miles

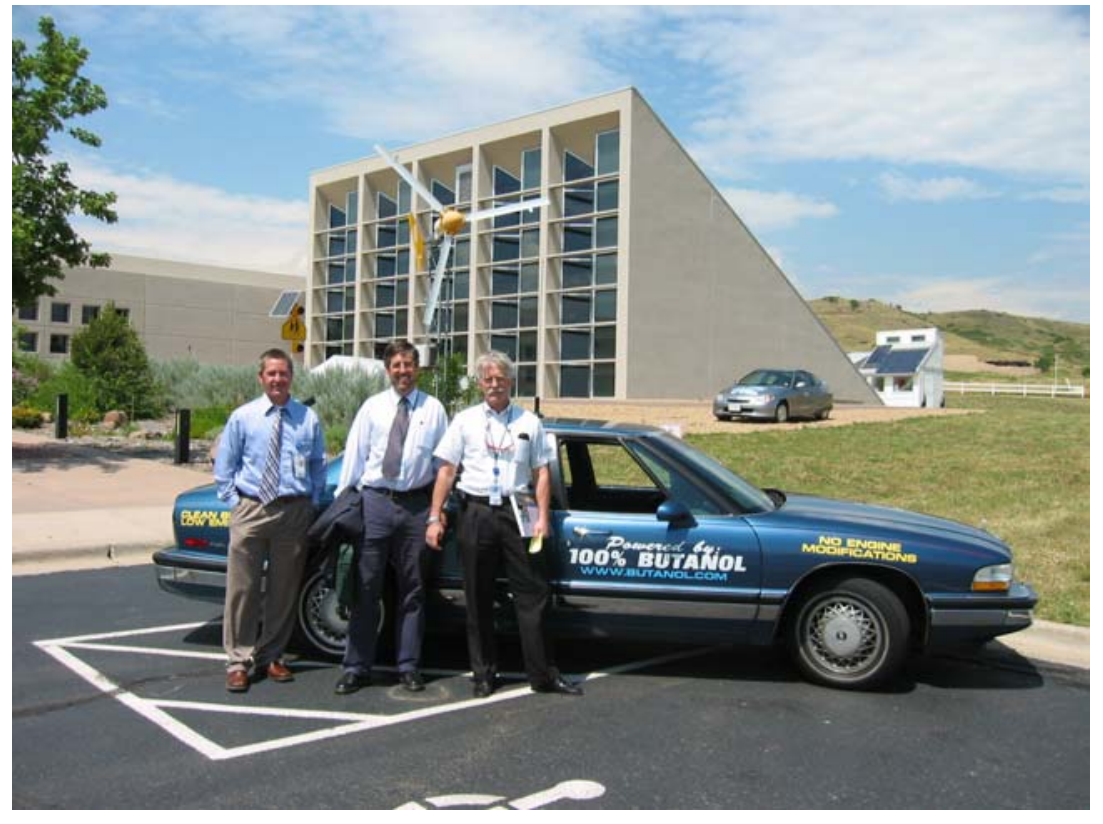

050815 Washington DC 9,518 miles go to "Ethanol/Butanol" legislation

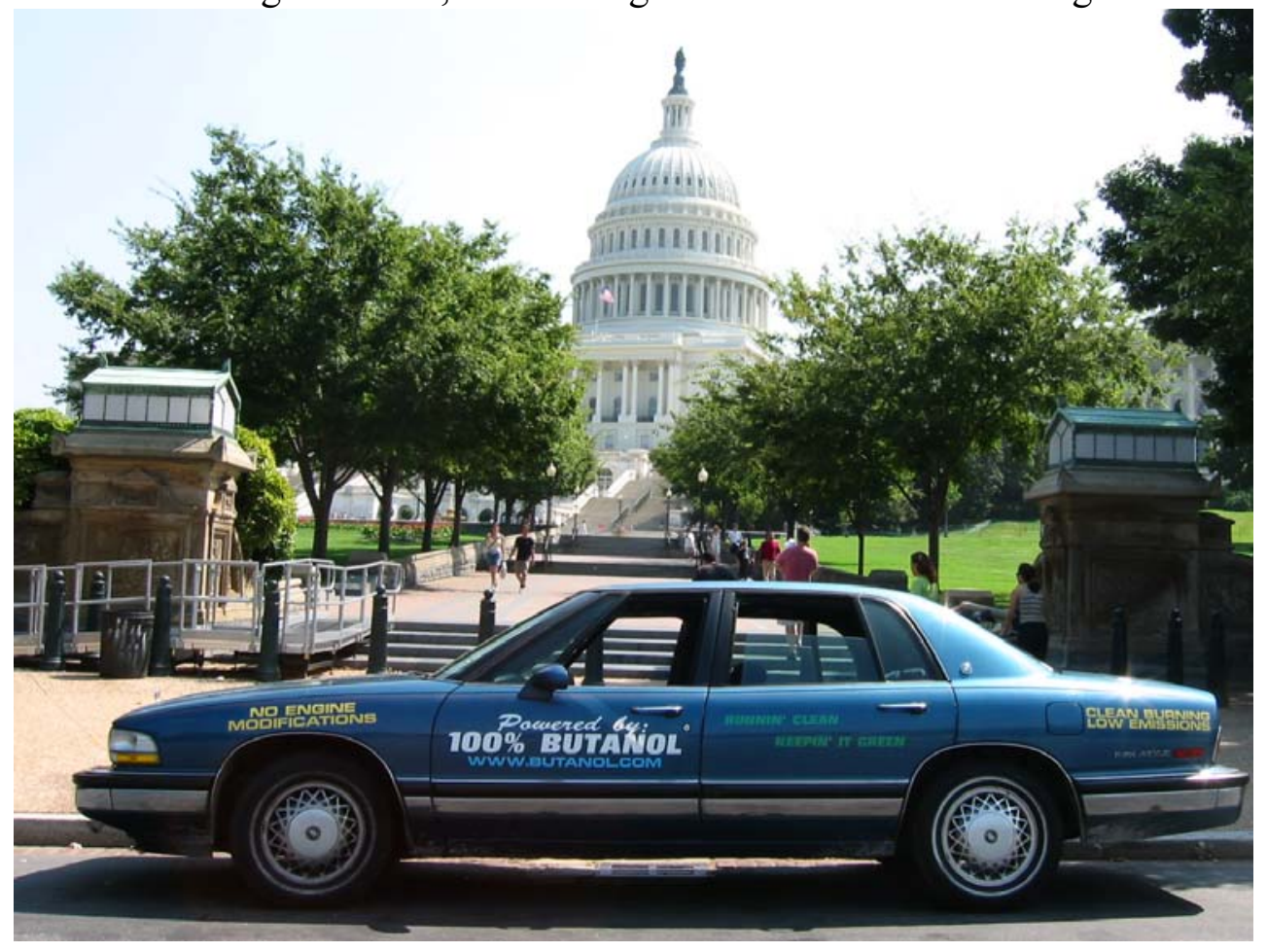

\section{And congress!}




\section{Over 10,000 miles around and across this great country on clean burning safe butanol ! \\ It truly does replace gasoline and can be made today from the same corn we choose to make ethanol from! Let us make more Butanol it works now !}

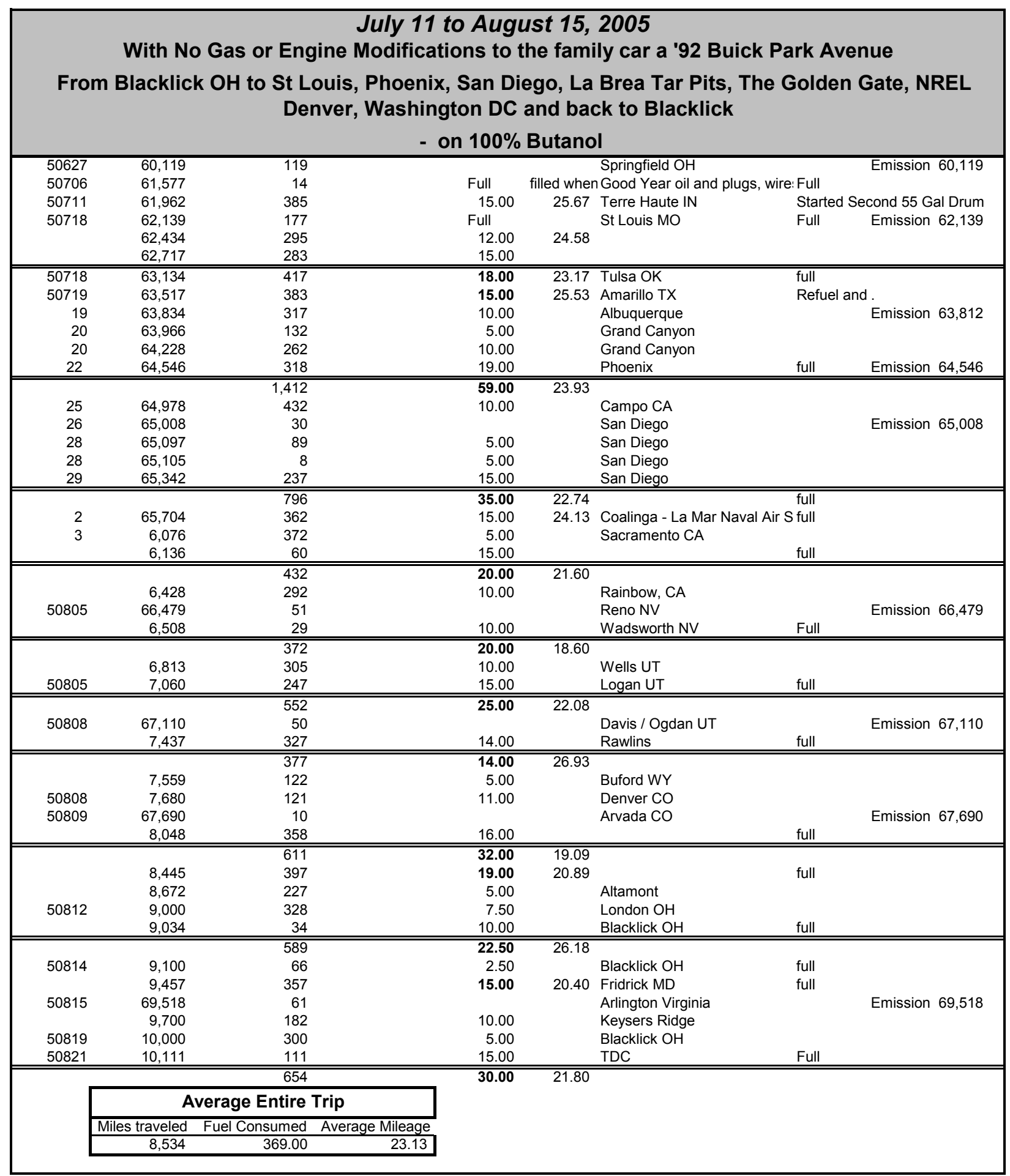









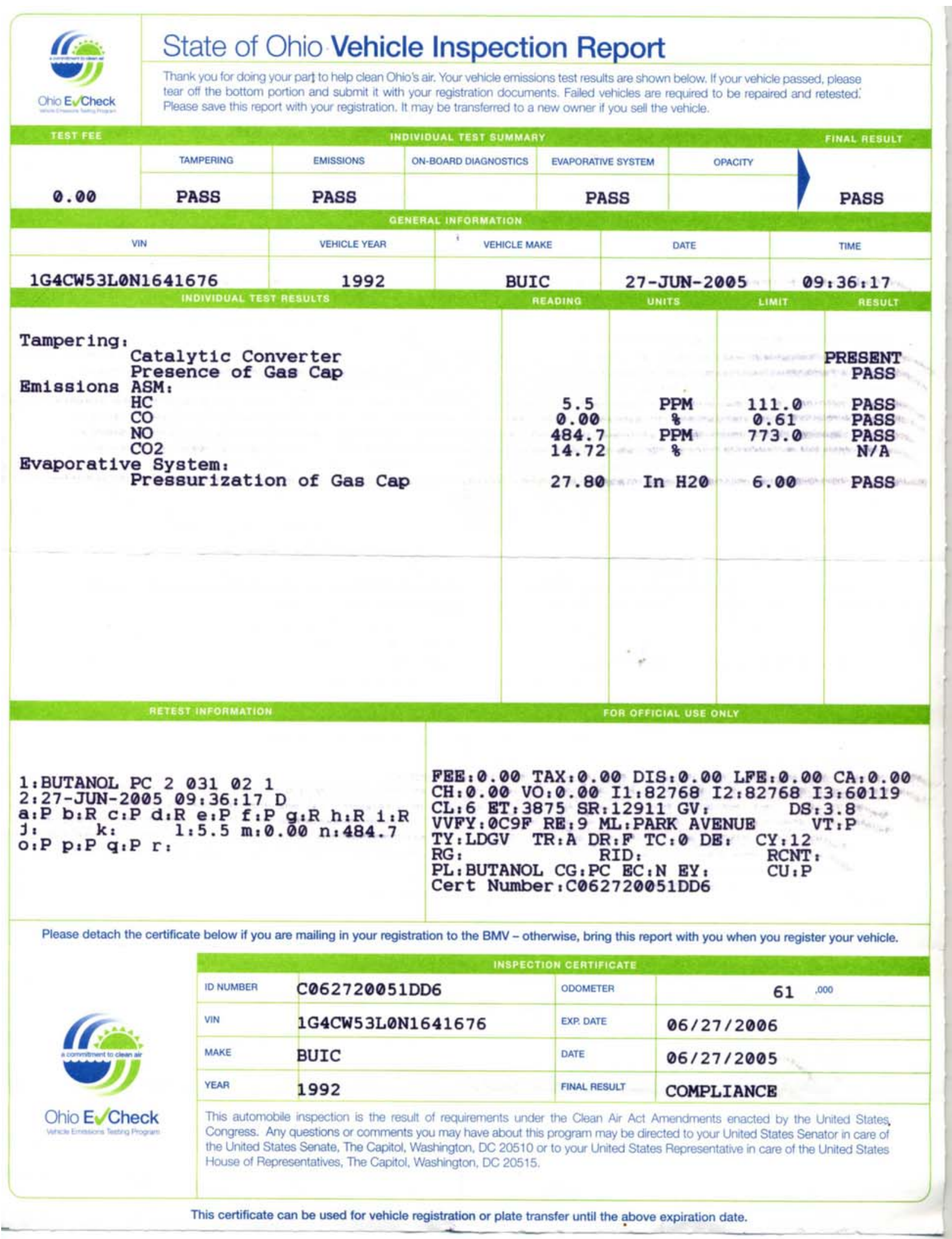




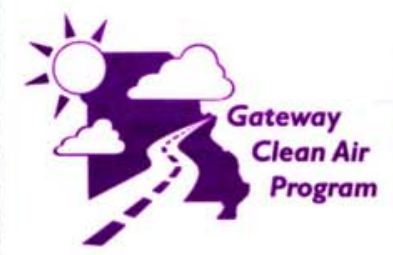

If your result is PASS or WAIVER, keep the certificate below in your vehicle.
Missouri Vehicle Test Report and Compliance Certificate

The vehicle identified below has been tested for exhaust emissions of Hydrocarbons $(\mathrm{HC})$, Carbon Monoxide (CO), and Oxides of Nitrogen (NOx). Your vehicle's gas cap has been checked for leaks and the on-board diagnostic system of 1996 and newer vehicles has been checked for emissions-related problems.

Overall Test Result If your result is FAIL, please read the My Vehicle Failed! PASS What Do I Do Now? brochure, see the customer service representative in the station office for more information, or call toll-free 1-888-748-9AIR (9247).

Vehicles produce excessive levels of emissions as a result of poor maintenance, equipment malfunction, or tampering with emissions controls. If not corrected, these problems result in poor fuel economy, shortened engine life and have a negative effect on air quality. Thank you for doing your part to help ensure the air we breathe is healthy.

\begin{tabular}{|c|c|c|c|c|}
\hline Emissions & HC Hydrocarbons & CO Carbon Monoxide & NOx Oxides of Nitrogen & $\mathrm{CO}_{2}{ }^{*}$ Carbon Dioxide \\
\hline $\begin{array}{l}\text { Standard: } \\
\text { Units: }\end{array}$ & GRAMS/MLE & GRAMS/MILE & GRAMS/MILF & GRAMSAMUIE \\
\hline Reading: - & 0.0000 & 0.1447 & 0.3416 & 122.2665 \\
\hline Result: & PASS & PASS & PASS & $\begin{array}{l}\text { *Advisory only. Does not } \\
\text { affect your Pass/Fail result }\end{array}$ \\
\hline Gas Cap Test & OBD Sys & heck & & Test Fee Paid \\
\hline
\end{tabular}

\section{Comments}

$\cdot$

\section{sTeat.Information}

\section{LANE: :}

DAIETTME: 18-JLL-2005 09:04:19

VDN: 1 GACWS3L0N1641676

PLATE: 1675

PLATE EXPIRATTON: $\pi L 2005$
CUTNTY: Ỳ

VEHICUI YEAR: 1992

MAKE: BUIC

VODEL: PARK AVEVIT

ODOMETER: $62 . \mathrm{XXX}$
OFFICIAL USE ONTY:

n. 1449

12: 1449

13: 1449

$\mathrm{CU}: \mathrm{M}$

VVFY: 6 AF

CA: 0.00

$\mathrm{CH}: 0.00$

CC: 0.00

co: 0.00

GVWR:0

Retest Information-Failed Vehicles Only

2:18- $\pi \tau-200509 \cdot 04: 19 \mathrm{E} 4448$

\section{State of Missouri}

201-JAN-1900 b.

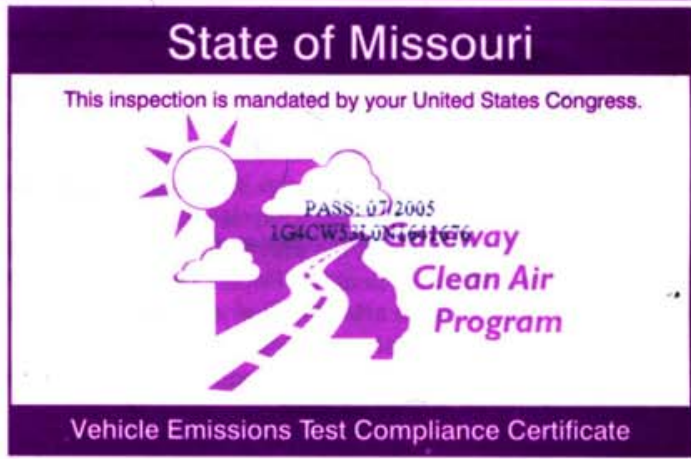

ment Act of 1994(643.300-355, RSM and 307.366 , RSMo. All testing is performed in accordance with these statutes 


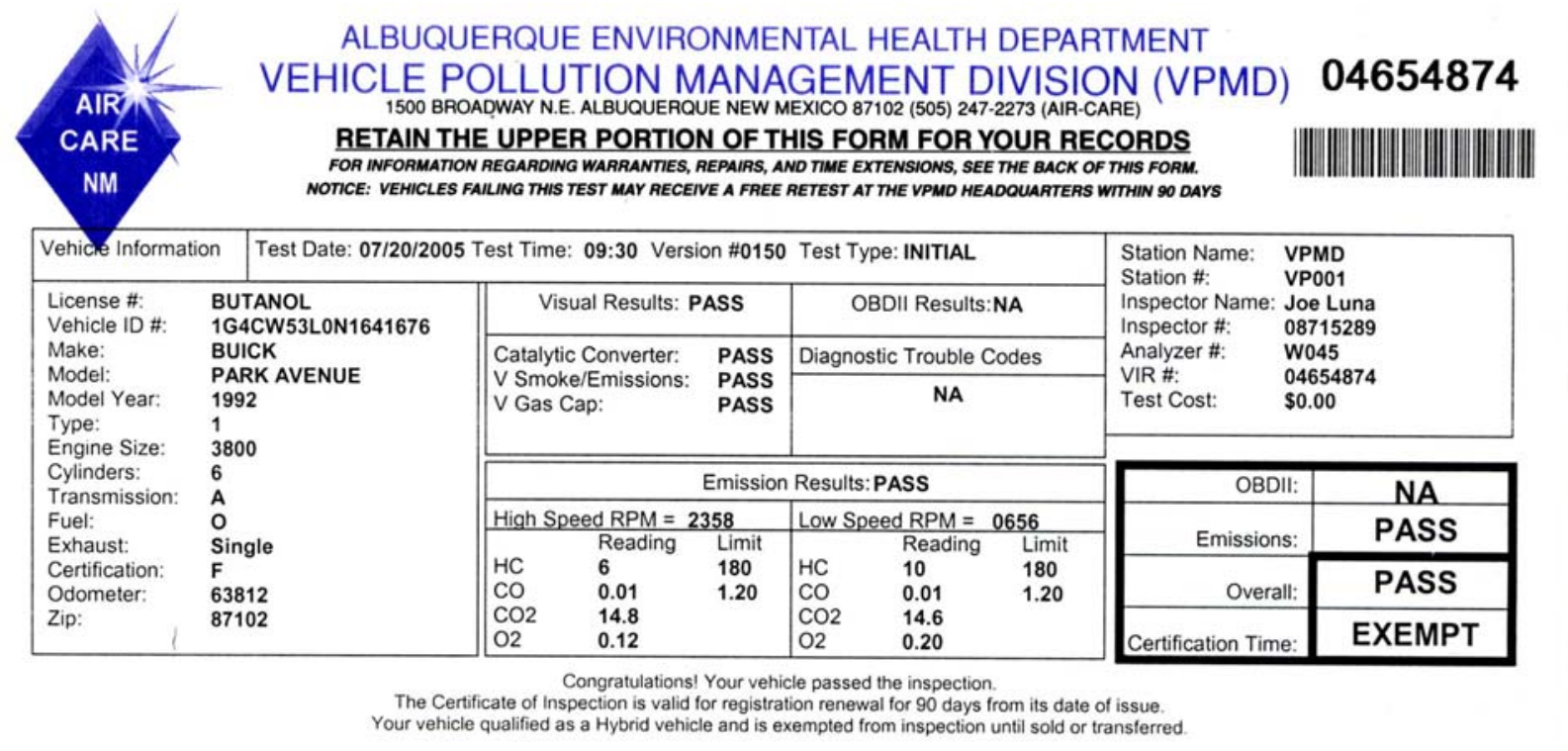

\section{Vehicle Pollution Management Program}

04654874

\section{3}

Pass Test Valid For 90 Days - Do Not Fold, Spindle, or Mutilate

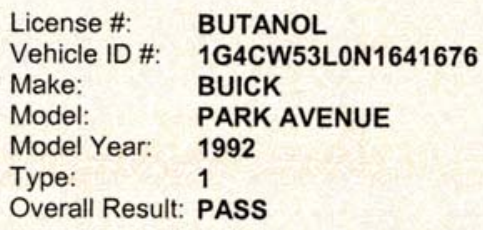

License \#: BUTANOL

Vehicle ID \#: 1G4CW53LON1641676

Make: BUICK

Model: $\quad$ PARK AVENUE

Model Year: 1992

Type: 1

Overall Result: PASS

\section{EXEMPT}

Station Name: VPMD

Station \#: VP001

Inspector Name: Joe Luna

Inspector \#: $\quad 08715289$

Analyzer \#: W045

VIR \#: $\quad 04654874$

\section{Test Date:07/20/2005}

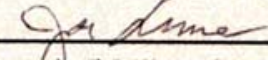
Ifertify that I have performed the emissions and all other official tests according to Albuquerque/Bernalitilo
County Air Quality Control Board Part 100 and the VPMD Procedures Manual. County Air Quality Control Board Part 100 and the VPMD Procedures Manual. 





Smog Check Vehicle Inspection Report (VIR)

Vehicle Information

Test Date/Time: 07/26/2005 @ 09:14

Model Year: 1992

License: BUTANOL

Engine Size: $3.8 \mathrm{~L}$

GVWR: N/A

Odometer: 65008

Fuel Type: Gasoline

Make:

BUICK

Model:

VIN:

PARK AVENUE

Type: Passenger

Transmission:

Test Weight: 3875

Certification: Federal

Cylinders:

Automatic

VLT Record \#: 12091

Exhaust: Single

Inspection Reason: Initial Registration

\section{Overall Test Results}

Comprehensive Visual Inspection: TAMPERED Functional Check: PASS Emissions Test: PASS

Repairing your vehicle is necessary to help California reduce smog-forming emissions and reach our air

quality goals.

\begin{tabular}{|c|c|c|c|c|c|}
\hline \multicolumn{6}{|c|}{$\begin{array}{l}\text { Emission Control Systems Visual Inspection/Functional Check Results } \\
\text { (Visual/Functional tests are used to assist in the identification of crankcase and cold start emissions which are not measured during the ASM test) }\end{array}$} \\
\hline $\begin{array}{l}\text { Result } \\
\text { Pass } \\
\text { Pass } \\
\text { N/A } \\
\text { N/A } \\
\text { Pass } \\
\text { Pass } \\
\text { Pass } \\
\text { N/A }\end{array}$ & $\begin{array}{l}\text { ECS } \\
\text { PCV } \\
\text { Catalytic Converter } \\
\text { EGR Visual } \\
\text { EGR Functional } \\
\text { Fuel Cap Functional } \\
\text { Fuel Cap Visual } \\
\text { Spark Controls } \\
\text { Fuel Evaporative Cor }\end{array}$ & $\begin{array}{l}\text { Result } \\
\text { N/A } \\
\text { N/A } \\
\text { Pass } \\
\text { N/A } \\
\text { Pass } \\
\text { Pass }\end{array}$ & $\begin{array}{l}\text { ECS } \\
\text { Thermostatic Air Cleaner } \\
\text { Air Injection } \\
\text { Vacuum Lines to Sensors/ } \\
\text { Switches } \\
\text { Ignition Timing: } \\
\text { Wiring to Sensors } \\
\text { Fillpipe Restrictor }\end{array}$ & $\begin{array}{l}\text { Result } \\
\text { Pass } \\
\text { Pass } \\
\text { Pass } \\
\text { Modified } \\
\text { Pass } \\
\text { Pass }\end{array}$ & $\begin{array}{l}\text { ECS } \\
\text { Fuel Evaporative Controls } \\
\text { MIL/Check Engine Light } \\
\text { Carb./Fuel Injection } \\
\text { Other Emission Related } \\
\text { Components } \\
\text { Oxygen Sensor } \\
\text { Liquid Fuel Leaks }\end{array}$ \\
\hline
\end{tabular}

ASM Emission Test Results

\begin{tabular}{|c|c|c|c|c|c|c|c|c|c|c|c|c|c|}
\hline & & $\% \mathrm{CO}_{2}$ & $\% \mathrm{O}_{2}$ & & (PPM & & & $0(\%)$ & & & 0 (PPM & & \\
\hline Test & RPM & MEAS & MEAS & MAX & AVE & MEAS & MAX & AVE & MEAS & MAX & AVE & MEAS & Results \\
\hline $15 \mathrm{mph}$ & 1559 & 14.3 & 0.0 & 106 & 31 & 6 & 0.70 & 0.10 & 0.01 & 762 & 237 & 715 & PASS \\
\hline $25 \mathrm{mph}$ & 1509 & 14.3 & 0.0 & 81 & 20 & 5 & 0.57 & 0.09 & 0.01 & 701 & 199 & 581 & PASS \\
\hline
\end{tabular}

Need help with your vehicle's failed smog check? You may be eligible for financial assistance to repair or retire your car. To get an

application to see if you and your vehicle qualify, visit the Bureau of Automotive Repair's website at www.smogcheck.ca.gov, or call toll-free

at 1-800-952-5210. YOUR APPLICATION MUST BE APPROVED BEFORE YOU RECEIVE VEHICLE REPAIR OR RETIREMENT ASSISTANCE.

No match has been found or test has been performed offline. The Consumer is responsible for retaining the VIR for reference throughout the vehicle registration process.

\section{Smog Check Inspection Station Information}

Consumer Assistance Referee Cente

10440 Black Mountain Rd. San Diego, CA 92126

Technician Name/Number:

KLUCH ARTHUR JACOB/EA 142962

1-800-622-7733

Repair Tech Name/Number:

Software Version/EIS Number: 0350/ES987331

Station Number: XF799204

I certify, under penalty of perjury, under the laws of the State of California, that 1 pefformed the inspection in accordance with all bureau requirements, and that the information listed on this vehicle inspection report is trige and alcyrate.

$7 / 26 / 2005$ 


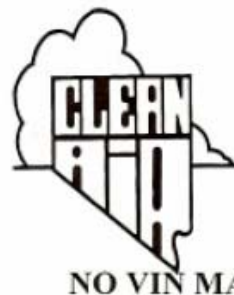

NEVADA

VEHICLE INSPECTION REPORT (VIR)

OVERALL INSPECTION RESULTS: PASSED

NO VIN MATCH IN THE VEHICLE REGISTRATION RECORDS.

THIS VEHICLE INSPECTION REPORT MUST BE PRESENTED FOR VEHICLE REGISTRATION.

\section{BAR CODED VIN:}

\section{VEHICLE INFORMATION}

\begin{tabular}{|l|l|l|}
\hline Year: 1992 & Cylinders: 06 & County: Other \\
Make: BUIC & Type: Passenger & ZIP: 43068 \\
Plate No: Non-NV & GVWR: N/A & Odometer: 66479 \\
VIN: 1G4CW53L0N1641676 & Fuel: Gasoline & Inspection Type: Initial Inspection \\
\hline
\end{tabular}

TAILPIPE RESULTS

VISIBLE SMOKE: PASS

\begin{tabular}{|l|l|l|l|l|l|l|l|l|l|}
\hline & \multicolumn{4}{|l|}{ HC ppm } & \multicolumn{2}{l|}{$\mathrm{CO} \%$} & $\mathrm{CO} 2$ & $\mathrm{O} 2 \%$ & RPM \\
\cline { 2 - 10 } & $<=$ Limit & Reading & Result & $<=$ Limit & Reading & Result & Result & Result & Result \\
\hline $2500 \pm 300$ & 220 & 10 & PASS & 1.20 & 0.00 & PASS & 14.70 & 0.1 & 2573 \\
Idle $775 \pm 425$ & 220 & 9 & PASS & 1.20 & 0.00 & PASS & 14.60 & 0.1 & 658 \\
\hline
\end{tabular}

\begin{tabular}{|l|l|l|l|l|l|}
\hline \multirow{3}{*}{ TAMPER RESULTS } & Air Inj. System & EGR System & Catalyst & Fuel Inlet Restrictor & Gas Cap \\
\hline N/A & N/A & PASS & PASS & PASS \\
\hline
\end{tabular}

TEST INFORMATION

\begin{tabular}{|c|c|c|c|}
\hline \multirow[t]{2}{*}{$\begin{array}{l}\text { Station No: WEA000 } \\
\text { Analyzer No: W701 } \\
\text { Inspector No: } 10045907\end{array}$} & $\begin{array}{l}\text { Test Date: 08/05/05 } \\
\text { Start Time: 09:51:46 AM } \\
\text { End Time: 10:01:57 AM }\end{array}$ & \multicolumn{2}{|c|}{$\begin{array}{l}\text { DMV ID: } 9447618 \\
\text { VIR No: H207145 }\end{array}$} \\
\hline & $\begin{array}{l}\text { VIR Certification Fee: } \\
\text { Electronic Transmission Su } \\
\text { Inspection Fee: } \\
\text { Total Fee: }\end{array}$ & Fee: & $\begin{array}{l}\$ 06.00 \\
\$ 02.06 \\
\$ 00.00 \\
\$ 08.06\end{array}$ \\
\hline
\end{tabular}

This Emission Test Valid For Registration Purposes For 90 Days Upon Date Of Issuance. 


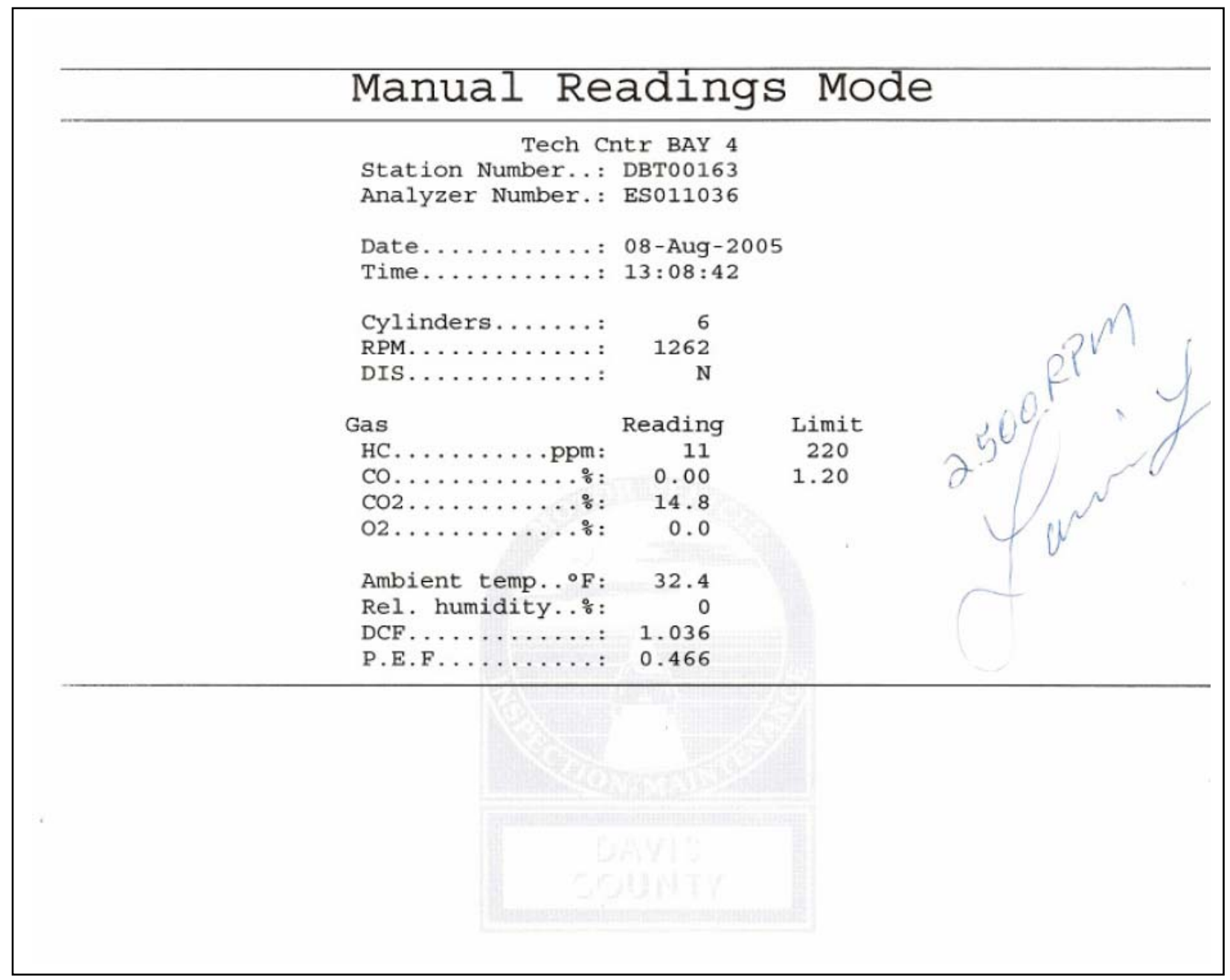

Utah - Davis County

\section{Manual Readings Mode}

Tech Cntr BAY 4

Station Number. : DBT00163

Analyzer Number.: ES011036

Date........: 08-Aug-2005

Time........ 13:08:01

Cylinders...... $\quad 6$ : $\quad 328$



DIS......... N

\begin{tabular}{|c|c|c|}
\hline Gas & Reading & Limit \\
\hline HC ........ ppm: & 22 & 220 \\
\hline CO........... & 0.00 & 1.20 \\
\hline $\mathrm{CO} 2 \ldots \ldots \ldots \ldots$. & 14.7 & \\
\hline $02 \ldots \ldots \ldots \ldots$ \% : & 0.1 & \\
\hline Ambient temp. ${ }^{\circ} \mathrm{F}:$ & 32.4 & \\
\hline Rel. humidity...\%: & 0 & \\
\hline DCF . . . . . . & 1.043 & \\
\hline P.E.F....... & 0.466 & \\
\hline
\end{tabular}

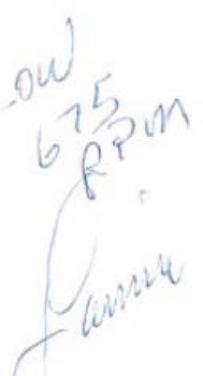









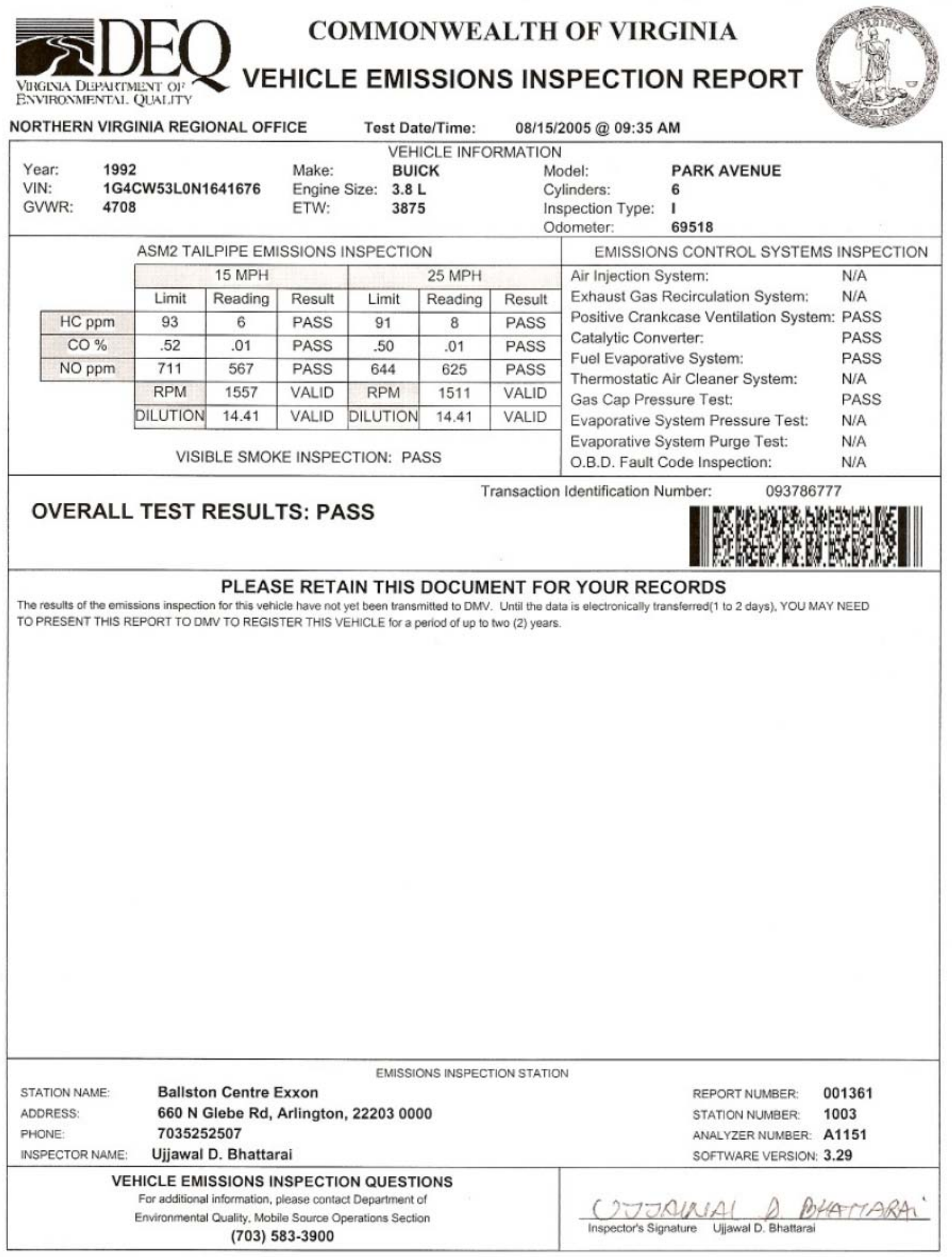




\title{
"Cheating the pump; Commuters, researchers nationwide look for cheaper, cleaner alternatives to oil"
}

\author{
Mike Lafferty, THE COLUMBUS DISPATCH
}

Columbus Dispatch (Ohio)

July 21, 2005

It's in paint thinner, brake fluid and perfume. And right now it's running David Ramey's 1992 Park Avenue. "It cuts emissions by 95 percent and the car runs great," the 62-year-old Blacklick inventor said last week before aiming his butanol-powered Buick toward San Diego on a month long trip to visit college friends. The trek is actually a ruse to promote butanol, which is made commercially from petroleum. Ramey has developed a method to make butanol from corn, grass, dairy whey and other biomass.

Ramey said it's the alternative fuel of the future.

The same has been said about french-fry grease, electricity, hydrogen fuel cells and other biomass compounds.

And as oil prices continue to climb, the interest in these alternatives continues to grow.

Ramey said butanol makes more sense than ethanol, which -- with the help of government subsidies and mandated-production quotas -- now is blended with many gasolines.

"You can't put 100 percent ethanol in your car and drive down the road."

Using a \$600,000 federal grant, Ramey and Ohio State University chemist S.T. Yang developed a fermentation process that produces butanol for about $\$ 1.25$ a gallon, roughly the same price as ethanol. A bushel of corn yields $21 / 2$ gallons of both fuels, but butanol packs about 25 percent more energy.

Ramey has continued to refine the process and makes small quantities of butanol in an elaborate backyard lab. He is looking for investors willing to put up $\$ 3$ million for a 1,000-gallon-a-week pilot plant.

In his lab, he can produce a gallon here, a gallon there. That's why a friend is following Ramey in a truck to San Diego carrying four 55-gallon drums of butanol they bought from Ashland Chemical.

If anyone asks, he'll show them a state vehicle-inspection test that reports hydrocarbons and nitrogen oxides well below federal standards and zero carbon monoxide. 
With huge, new demand for oil in India and China, experts are looking at whether alternative fuels can stretch or eventually replace petroleum supplies.

Depending on the forecast, oil production has topped out, will peak within five years, or, according to the federal government, keep increasing until sometime between 2050 and about 2100 .

U.S. oil production peaked in 1970. In most countries, it's falling, despite huge increases in prices that have pushed exploration.

Higher prices and increased efficiency could stretch supply, according to David Morehouse, senior petroleum geologist at the federal Energy Information Administration.

Many energy experts say world production has peaked and future production will decline every year.

If that happens, predictions of $\$ 100$-a-barrel oil may not be unrealistic.

Accompanying gasoline-price spikes could spur interest in alternatives.

There still is a long way to go. For example, ethanol never has made sense except in converting energy from one form -- corn -- to another.

"It costs more to produce it than the energy you get out of it," Morehouse said.

Ohio's only ethanol plant at South Point went bankrupt, and plans to build other plants have not materialized.

Still, rising oil prices have made ethanol a player of sorts.

"Today, ethanol would be cheaper than gasoline, even without the (federal) subsidy," said Sam Spofforth, executive director of the Central Ohio Clean Fuels Coalition.

Ethanol-fuel production more than doubled between 1996 and 2004 to about 2 billion gallons, according to federal statistics. A provision in the Senate-passed version of the energy bill would boost mandatory renewable-fuels production to 8 billion gallons by 2012, pushing ethanol production even higher.

That's still a drop in the bucket. In April alone, Americans purchased 380 million gallons of gas a day, according to the federal energy group.

In the meantime, midsize hybrid gas-electric cars are getting the most public attention. They're big hits despite premium prices and waiting lists. 
"We were close to $60 \mathrm{mpg}$ on a trip to Florida," said William Meyer, of Columbus, who purchased a Toyota Prius in October. "If you have a heavy foot you aren't going to get really good mileage. You start accelerating fast, you start sucking out the gas."

Of course, for a midsize hy-brid, that is still in the $45 \mathrm{mpg}$ range.

At Ohio State's Center for Automotive Research and Intelligent Transportation, a Ford Explorer has been modified and fitted with a hybrid diesel-electric power plant that boosted mileage about 50 percent to $28 \mathrm{mpg}$ on the open road.

"That vehicle was powered with biodiesel, diesel with 35 percent soybean oil. When it runs it smells like French fries," said Don Butler, the center's research-project director.

When hybrid cars started showing up in new-car showrooms, even combined with gasoline engines, it was time for science to move on.

The OSU research center is junking storage batteries for its high-speed electric Buckeye Bullet test car and is concentrating on a hydrogen fuel cell, which will convert hydrogen to electricity for power.

Cost, weight and efficiency of automotive fuel cells remain shortfalls, but can be overcome, said Battelle scientist Jay Sayre.

And while hydrogen can be made from fossil fuels, the process still creates carbon dioxide, which affects climate change.

Even making it out of ethanol, butanol or methane still yields carbon dioxide.

Using solar or hydroelectric power to split hydrogen from water is a pollution-free method, Sayre said, but it is difficult to do.

Nevertheless, Ohio State is forging ahead. A hydrogen fuel station is scheduled to open at the automotive-research center on Kinnear Road in about a month.

At this point, however, the only vehicle it will power is a golf cart.

mlafferty@dispatch.com 


\section{Tribune Star}

Saturday, July 16, 2005 -

Serving Terre Haute and the Wabash Valley

\section{"Ohio man touts butanol as alternative to gasoline"}

By, Peter Ciancone - Tribune Star.

From a distance, David Ramey's Buick looks like a run-of-the-mill, blue 1992 Buick Park Avenue with to many bumper stickers.

Up close, the writing advertises his product with his Web address and the slogan, "Runnin' clean - Keepin' it green."

Ramey, from Columbus Ohio, stopped in Terre Haute on the first leg of a cross-country trip that has turned into a touring demonstration to advertise his company's alternative to gasoline: butanol.

Because former Terre Haute manufacturer Commercial Solvents produced butanol from 1920 until the mid-1950s, he said, Terre Haute was on his itinerary.

Picture of: Ohio License Tag "BUTANOL" It's a bute: David Ramey's license plate hawks the use of butanol as a fuel - Tribune-Star Jim Avelis

"Butanol: Ramey says fuel safe, clean, and easy to produce"

Terre Haute was my first choice of places to go,” Ramey said.

With the clear-eyed conviction of an evangelist, the former Navy submariner turned physicist/businessman touts butanol as safe, clean and easy to produce with his patented fermentation process, requiring only minor modifications to a car's carburetor and timing to run.

"All I did was put butanol in it instead of gasoline," Ramey said of his Buick. Well, there's a little yellow cylinder under the hood to help the car start because butanol ignites later than gasoline, but that's it.

He's driving to California, bringing along four 55-gallon drums of his fuel. Since he's getting 24 miles per gallon with the butanol - the car normally gets about 20, Ramey said - he may need to buy more in Phoenix and Los Angeles. If he does get in a bind, he can just switch back to burning gasoline.

Butanol is an alcohol once produced as a byproduct of acetone fermentation. Commercial Solvents made it for about four years in the early 1920's before they know what to do with it, said local historian Mike McCormick. 
Eventually, the company found a use for it as a solvent. Now, using a different process, Ramey said he can produce about 2.5 gallons of butanol per bushel of corn. It also can be produced by fermenting other natural materials.

His idea started, he said, when the city of Columbus, Ohio, stopped picking up leaves, cut grass and limbs.

"I even ground up the college newspaper," Ramey said. Columbus is home to Ohio State University.

For about $\$ 1.23$ a gallon, his process produces a fuel that's safer. "You have to hold a match to it to light it," he said, conducting the demonstration with a small amount of the fuel spilled onto a glass mug on the hood of his car.

The exhaust shows 95 percent less hydrocarbons than gas exhaust, smaller reductions in carbon monoxide and nitrous oxides.

Ramey said.

Ramey makes several comparisons of his alternative to ethanol, an additive and fuel that has caught on in Indiana because it uses corn to fuel the fermentation. Indiana Sen. Dick Lugar coauthored legislation to help develop ethanol.

"I suspect if it's a cost-effective product, we'll see more and more of it over the years," said Ron Lamberty, director of market development for the American Coalition for Ethanol, on butanol.

While he didn't know much about the fuel as an alternative, Lamberty said that as an organization of farmers and energy-alternative activists, they are interested in all alternatives that might be produced within the United States.

"We don't look at other alternative fuels as competition," Lamberty said. "It would be inconsistent of us to say we like alternative fuel, but only our alternative fuel."

Ramey said it's probably years before the government could do the testing to verify his claims about butanol, and to bring enough of it on the market to make it reasonable alternative, but it ought to be considered.

"It's not even on the table as an alternative fuel," Ramey said. His tour is designed to make sure people start to put it there. "Everybody ought to know about it."

Picture of: Ramey: ON THE NET For more information about butanol and David Ramey's patent fro production of an alternative fuel to replace gasoline, log on at ww.butanol.com.

\section{BUTANOL'S ADVANTAGES}


- A higher energy content than ethanol (105,000 Btu per gallon versus 84,000 Btu per gallon in ethanol). Gasoline contains about 115,000 Btu per gallons.

- It can be shipped through existing pipelines.

- It can be used as an immediate replacement for gasoline with only minor modifications to a vehicle's carburetion and timing.

Source: Environmental Energy Inc, David E. Ramey, president

Peter Ciancone can be reached at (812) 231-4253 or pete.ciancone@tribstar.com

\section{"With a dream in the gas tank, he headed west"}

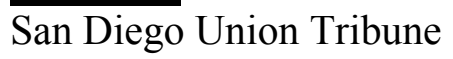

\section{By Scott LaFee}

STAFF WRITER

August 3, 2005

On a recent Tuesday afternoon, David Ramey drove into San Diego from Blacklick, Ohio, a circuitous trip that covered 13 days and several thousand miles.

Ramey, a 62-year-old fellow with an earnest and outgoing manner, was elated by the feat, thrilled enough to almost immediately inform the newspaper.

Now it's not ordinarily news when a former alfalfa and sprouts farmer comes to town. But Ramey says he drove here ... a meandering, sightseeing trip of more than 5,500 miles ... in an unmodified metallic blue 1992 Buick Park Avenue without ever stopping for gas. Indeed, he claims to have not used gas at all. His chosen fuel was butanol, which like its better-known cousin, ethanol, is derived from corn but which, unlike ethanol, almost nobody is touting as a renewable, nonpolluting fuel of the future.

The U.S. Department of Energy's Alternative Fuels Data Center, a clearinghouse for alternative fuels research and programs, doesn't list it. Neither does the National Renewable Energy Laboratory (NREL) nor the DOE's Energy Efficiency and Renewable Energy program.

"Which is why I made this trip," says Ramey, "to prove that butanol works as a fuel, to get people's attention. You can just pour this stuff into your car and drive."

Ramey is no hick from the sticks. He worked on submarine nuclear reactors in the Navy, earned degrees in physics and math from SDSU, then worked in the nuclear and optics industries before finally moving back to the family farm in Blacklick, a community of 9,518 located 10 miles southeast of Columbus. 
There, Ramey says he helped spawn a regional market for what he calls "living foods", such as bean sprouts. Like all crops, his 3,000-acre farm produced an unending and problematic stream of biowaste.

So Ramey purchased equipment to convert the waste into ethanol, a project that ended abruptly when his conversion plant exploded. In 1979, he read an article about butanol, an industrial solvent commonly used in inks, disinfectants, fungicides and perfume. The worldwide market for industrial butanol is about $\$ 4$ billion. A gallon of the clear liquid sells for $\$ 3.75$.

Commercial use of butanol began in 1916, when Chaim Weizmann, a scientist and eventually the first president of Israel, invented a process employing a bacterium called Clostridium acetobutylicum to convert fermented corn starches into acetone, which could then be used to make dynamite. Butanol and ethanol were byproducts of the fermentation process, but soon found uses as well.

Over time, Weizmann's process was refined, but it remained slow, complicated and laborious. Butanol can be toxic to $C$. acetobutylicum, so the bacterium necessarily produces the chemical in relatively minuscule, dilute amounts. When scientists began investigating biofuels in the 1950s, ethanol seemed more promising than butanol. It was cheaper to produce in larger quantities. The notion of butanol as a future fuel evaporated.

But Ramey was intrigued, and the more he investigated butanol, the more he believed it superior to ethanol as a fuel.

Ramey says his research, conducted through his company, Environmental Energy Inc. and funded in part by a $\$ 600,000$ grant from the Department of Energy and several local investors, shows that butanol produces more energy per gallon than ethanol, thanks to its more complex molecular structure.

A molecule of ethanol is composed of two carbon atoms, six hydrogen atoms and an atom of oxygen. Butanol boasts twice as many carbon atoms, 10 hydrogen atoms and an oxygen atom.

That extra carbon, said Ramey, translates into a 25 percent increase in harvestable energy, which is measured in British thermal units or BTUs. A gallon of ethanol contains roughly 84,800 BTUs, according to data posted by Ramey at his Web site, www.butanol.com. A gallon of butanol contains 104,500. A gallon of gasoline contains 115,000 BTUs.

"You get about the same amount of butanol as ethanol from a bushel of corn - about 2 $\frac{1}{2}$ gallons - but you get more energy out of a gallon of butanol," he said. In practical terms, that means better gas mileage.

To be sure, Ramey had no data to back up his mileage claims until his trip to San Diego. In his Blacklick lab, he had produced only enough butanol to run a lawn mower. The cross-country drive was his first real-world experiment, which he conducted with a friend following in a supply van loaded with four 55 -gallon drums of butanol. 
"I had my fingers crossed. This was a gamble. But the car performed flawlessly," said Ramey, enthusiastically. "We had no problems. With gas, my Buick gets about 18 miles per gallon. With butanol, we're getting 25 or $26 . "$

As a fuel, Ramey contends that butanol offers numerous advantages over ethanol and other fuels:

It can be derived from any sort of biomass, from corn to weeds to cheese whey.

It is less evaporative and volatile than other fuels, and so safer to handle and use.

(Without warning, Ramey illustrated this point by pouring a small vial of butanol onto a table in the newspaper's cafeteria, then attempted to ignite it with a lighter. Nothing happened, until he dipped a bit of torn paper napkin into the puddle. The butanol wicked up the napkin and ignited easily. Ramey pats out the small conflagration and beams.)

It is less corrosive. It can be transported through existing oil and gas pipelines. Ethanol cannot. Similarly, it is not damaging to automobile components, such as valves and gaskets.

It produces relatively little pollution. Ramey's Buick has been smog tested along the way. In every case, he says, measured emissions of pollutants such as hydrocarbons, carbon monoxide and nitrogen oxides have been substantially lower or nonexistent compared with gasoline.

It requires no modification to gasoline-powered engines. Ramey says he pours butanol straight into his Buick's tank, with no adverse effect on the car's operation.

"Butanol could be a player in transportation fuels," said Jim McMillan, a senior biochemical engineer at NREL. "The big challenge is cost. It's a lot more difficult to make by fermentation than ethanol because butanol is so much more toxic to the organism. That makes it hard to produce it in high enough concentrations. But people are talking about it."

Ramey hopes his journey, which will conclude back in Blacklick in a few weeks, will get people talking about him and his ideas. He claims to have developed a two-stage fermentation system that solves the problem of organism toxicity. Now, he says, he simply needs the financial support to build a larger pilot project, one that would put his manufacturing process to the test.

Ramey says he's confident it will work, and that it can produce butanol on a massive scale at a cost similar to ethanol. (Currently, a gallon of ethanol sells for about \$2.40 retail in San Diego.)

"I would like to build a test plant that could produce 1,000 gallons a week of butanol. That will cost maybe \$3 million," said Ramey, smiling. "I'm hoping to find a sponsor who will look at this idea and say, here's the money." 